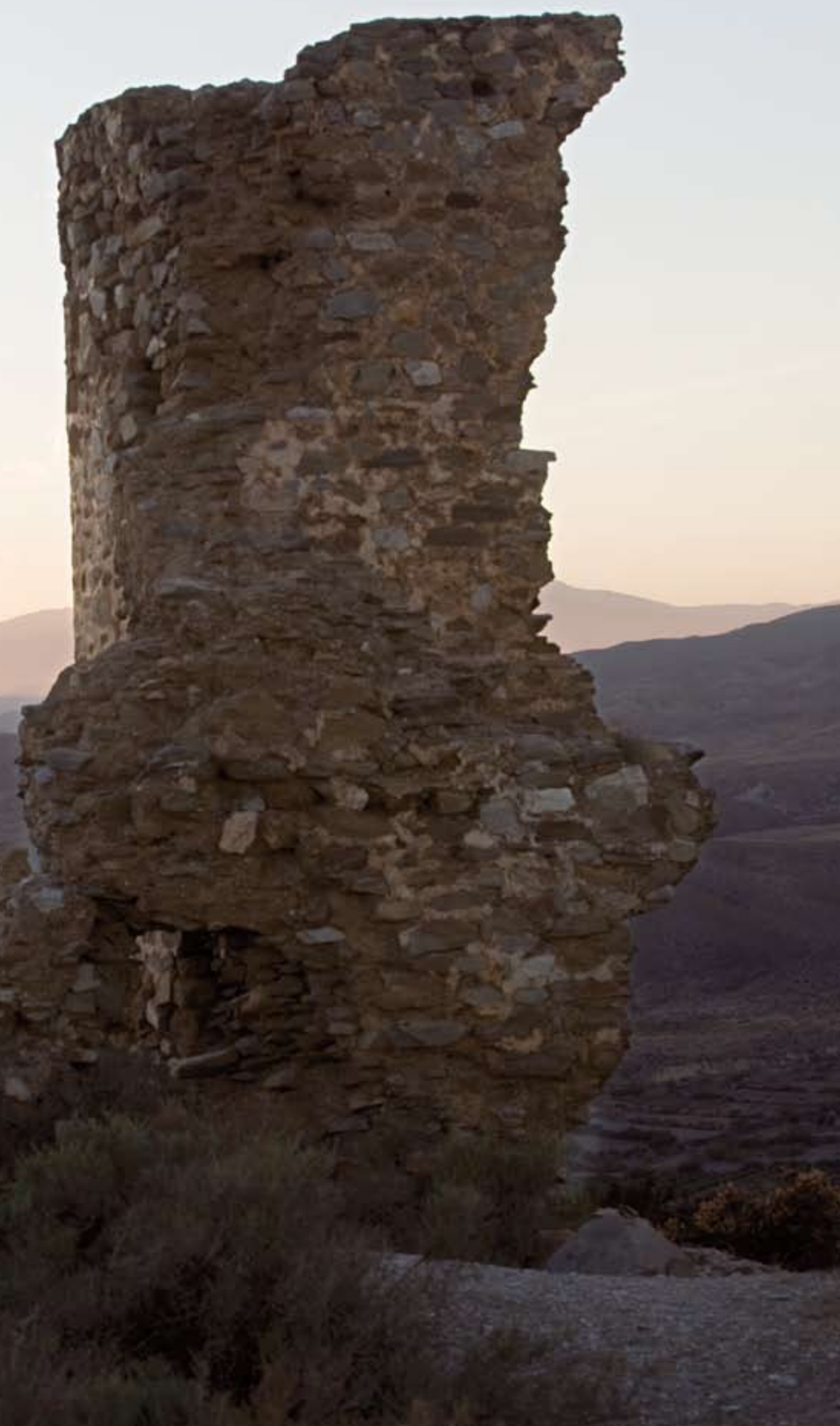




\section{Andarax y valle de Tabernas}

Esta sección ha sido elaborada,

además de por los firmantes, gracias

a la colaboración de Aniceto Delgado

Méndez, Isabel Durán Salado, Silvia

Fernández Cacho, Luisa Fernanda de

Juan Santos, Valle Muñoz Cruz, Lorena

Ortiz Lozano, Carmen Pizarro Moreno,

David Villalón Torres

En los valles del Andarax y del Tabernas podemos apreciar la oposición secano-regadio propia del paisaje mediterráneo; los fuertes contrastes entre una zona semiárida y árida, con unas montañas muy erosionadas y desertificadas y el contrapunto del verde de las zonas agricolas de las vegas que forman el río Andarax y las diferentes ramblas que lo constituyen. Se trata de un paisaje vivo, en permanente evolución, sometido quizás a un momento de cambio e incertidumbre.

Hace casi sesenta años la idiosincrasia de este paisaje cautivó la mirada de los cineastas y desde entonces se han venido creando innumerables historias hechas de miradas, sombras y luces en este territorio imponente. El cine como metáfora de una Historia que ha dejado en el territorio huellas patrimoniales en forma de arquitectura defensiva, propuestas urbanisticas de la modernidad industrial, balnearios y jardines o yacimientos de indudable valor arqueológico.

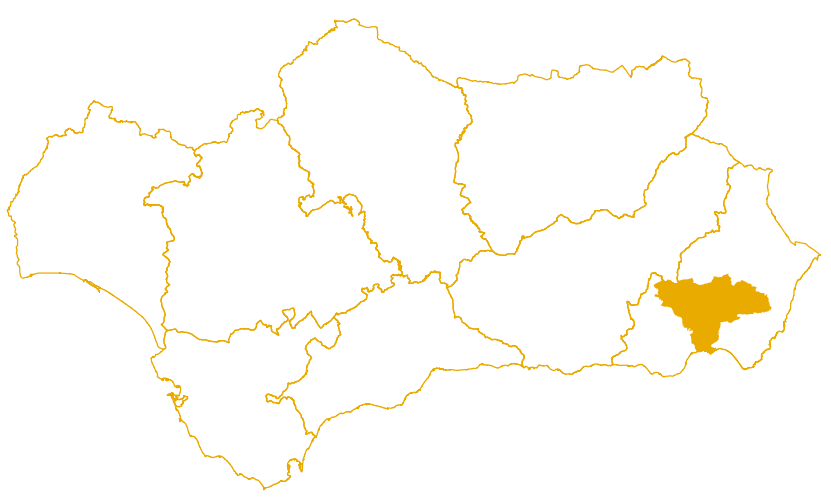




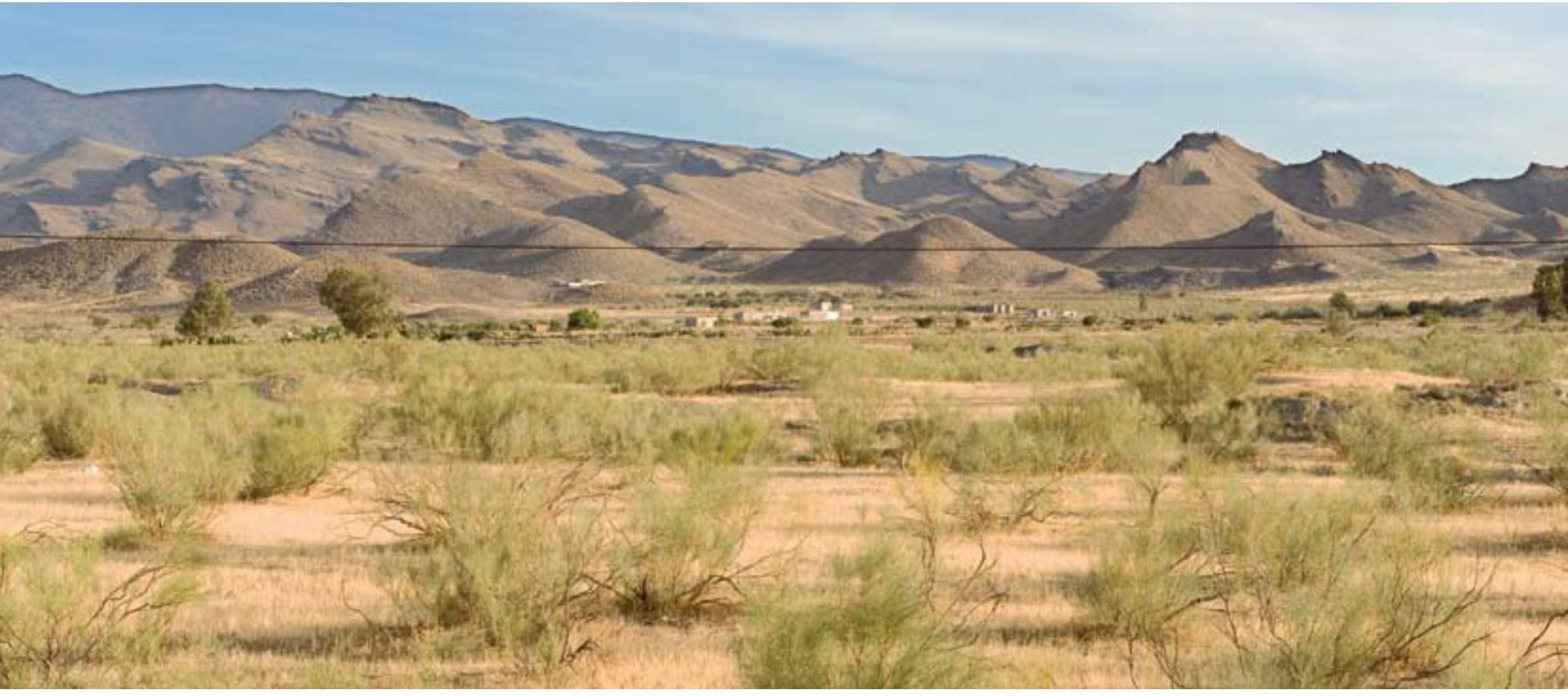

Vista del desierto de Tabernas desde la carretera que va desde Tabernas a Castro de Filabres y Velefique. Foto: Juan Carlos Cazalla, IAPH

En el valle del Andarax y en el de Tabernas podemos apreciar esta oposición secano-regadío, tan característica del paisaje mediterráneo, de fuertes contrastes entre una zona semiárida y árida, con unas montañas muy erosionadas y desertificadas y el contrapunto del verde de las zonas agrícolas de las vegas 


\section{Paisaje vivo, en permanente evolución}

Juan Salvador López Galán,

Departamento de Protección del

Patrimonio Histórico, Delegación

Provincial de Cultura de Almería

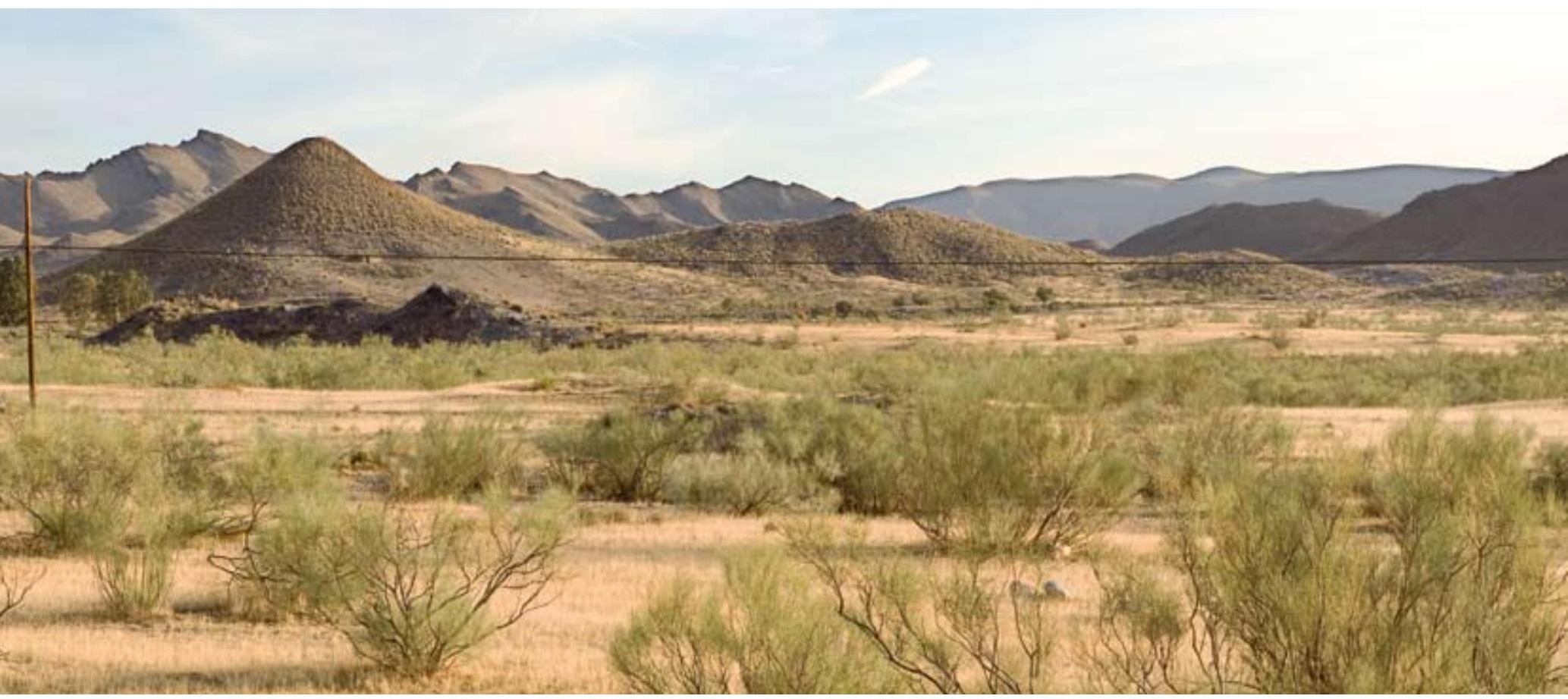

Almería es una tierra de contrastes que presenta paisajes muy diferentes desde el interior hasta la costa, entre las zonas montañosas de sierra de Gádor en La Alpujarra, la sierra de los Filabres y Sierra Maria y los valles que conforman los rios Andarax y Almanzora, con las singulares zonas desérticas de Tabernas, los Karts de yesos de Sorbas, y las calderas volcánicas de Rodalquilar (Nijar) y las dunas fósiles del Parque Natural de Cabo de Gata (Nijar).

En el valle del Andarax y en el de Tabernas podemos apreciar esta oposición secano-regadío, tan característica del paisaje mediterráneo, de fuertes contrastes entre una zona semiárida y árida, con unas montañas muy erosionadas y desertificadas y el contrapunto del verde de las zonas agrícolas de las vegas que forman el río Andarax y las diferentes ramblas que lo constituyen. Es un paisaje vivo, que sigue en permanente evolución, y que desde el cultivo del olivar y los frutales, con predominio de la morera en el siglo XVI, se pasó a la radical desforestación que conllevaba la minifundista minería del plomo del siglo XIX, y a la construcción de pequeñas terrazas de cultivo en laderas de fuertes pendientes y a la ampliación de la infraestructura de regadios, para el cultivo de los parrales de la uva de mesa desde mediados del siglo XIX y principios del XX. Posteriormente, dichos parrales fueron sustituidos por los cítricos actuales, con predominio del naranjo y los mandarinos.

Pero quizás este sea un nuevo momento de transición, de cambio e incertidumbre, donde el cultivo de los cítricos orientado a la comercialización, primero internacional y luego nacional, ha dejado de ser rentable por varias causas, entre las que destaca la pérdida de subvenciones comunitarias y el alto coste de producción y donde las pequeñas explotaciones son dirigidas por una generación a punto de jubilarse.

En esta sección de "Bienes, Paisajes e Itinerarios" abordaremos a continuación los diferentes periodos de ocupación del territorio, desde Los Millares a la arquitectura defensiva medieval, la industria del cine de mediados del siglo XX generada en los escenarios naturales del desierto de Tabernas, el patrimonio urbano de Ciudad Jardín de Almería, el Museo de Almería y el aprovechamiento histórico de las fuentes termales en los balnearios de Alhama y Sierra Alhamilla (Pechina). 


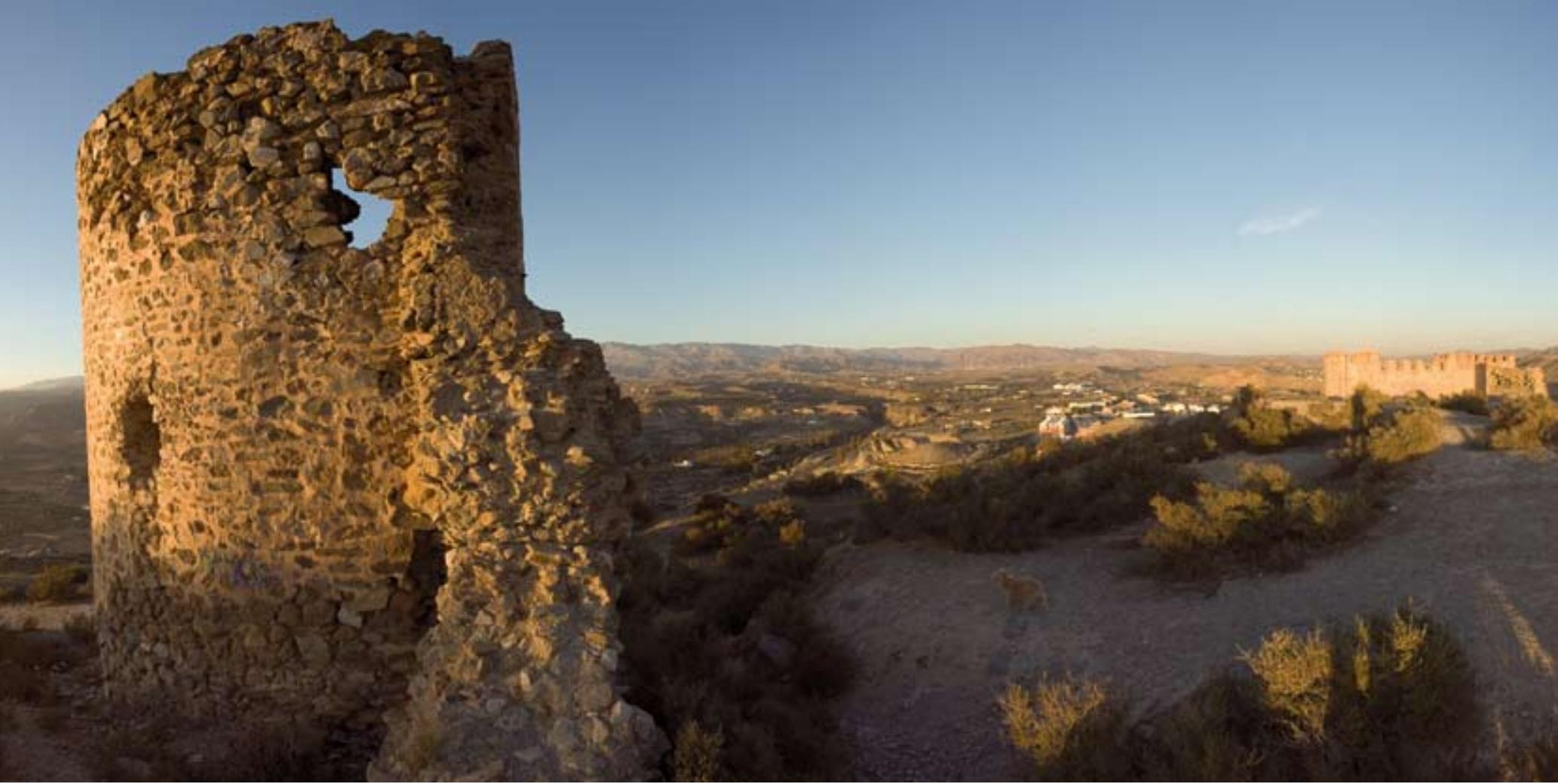

Castillo de Tabernas (Almería). Foto: Juan Carlos Cazalla, IAPH 


\title{
La arquitectura defensiva andalusí en la comarca del bajo Andarax y valle de Tabernas de Almería
}

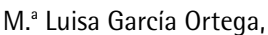 \\ Conjunto Monumental Alcazaba \\ de Almería
}

Con anterioridad a que los musulmanes conquistaran la Peninsula, ya existian en muchos puntos elevados y estratégicos de la provincia de Almeria estructuras defensivas, las cuales se aprovecharon, en algunos casos, para la construcción de castillos o alcazabas. Desgraciadamente, no todas se han conservado, y las que lo han hecho han sufrido innumerables transformaciones adaptadas a cada época. La degradación de este patrimonio, aunque menor que la que se produce en otros tipos de edificios coetáneos, es bastante elevada debido fundamentalmente al propio fin para el que fue concebido, pero sobre todo se ha visto sujeto a continuas reformas y restauraciones que en muchas ocasiones no han sabido respetar su aspecto original.

En el siglo VIII se asentaron en el valle del Andarax una serie de clanes árabes yemenies, dando origen a pequeñas poblaciones como Alcolea, Monterrubio, Fiñana, Huéneja, Marchena, Mondújar, Alboloduy y Benahadux. En los primeros tiempos de la ocupación árabe los asentamientos eran fundamentalmente rurales, como las alquerias, mientras que los principales puntos fortificados son las ciudades. Los enfrentamientos surgidos durante la formación de la sociedad andalusí en los siglos VIII y IX dan lugar a la construcción de castillos para la defensa del territorio (MALPICA, 2002: 64).

Según fuentes árabes, durante el siglo IX se levantaron numerosas construcciones defensivas en la zona de la costa almeriense por encargo de Abderramán II a tribus yemeníes. Este distrito será conocido como Urs al-Yaman, y su capital como Bayyana. Bayyana será la tercera cora del emirato de Córdoba, del que mantendrá una semiindependencia, con dirigentes propios, los Banu Aswad, uno de los cuales, Umar b.Aswad al Gassani, la rodeó de murallas y construyó a su cargo una espléndida mezquita, a semejanza de Córdoba (SEGURA, 1996: 461). Según Al-Udri, geógrafo andalusí nacido en Adra, la ciudad de Pechina creció, ampliándose su perímetro urbano ydotándolo de alcazaba. Así aumentaron y mejoraron sus servicios públicos, industriales y administrativos, uniéndose a otros civiles y religiosos, como la mezquita aljama. También se amplió el perímetro de su territorio, incorporándose al mismo una veintena de fortale- zas, entre las que se encontraban las del valle de Pechina, Alhama, Alhabia, Purchena, Bentarique, Nijar y Lucainena, dando lugar a un estratégico enclave defensivo y náutico (MOLINA, 2005: 18). Sin embargo, hasta ahora, no se han hallado restos de muchas de estas edificaciones defensivas. Las excavaciones arqueológicas Ilevadas a cabo en Pechina (ACIÉN; CASTILLO, MARTíNEZ, 1990: 147-168) constatan la existencia de viviendas, áreas de uso artesanal e industrial, y una necrópolis, pero nada dicen de una alcazaba. Habrá que esperar, por tanto, a futuras investigaciones, que ayuden a constatar la existencia de tan singular edificación.

En los años 954-955, el predominio adquirido por el puerto de Pechina, Al-mariyya Bayyana, Ilevará al califa Abderramán III a convertirlo en sede del almirantazgo califal y puerto de Córdoba, elevándolo a la categoria de medina. La Madinat Al-mariya, actual Almería, fue dotada de murallas y alcazaba (de las que más adelante hablaremos) para proteger a su población y mejorar sus servicios.

Durante el califato y sobre todo en el periodo taifa, los castillos y fortificaciones fueron numerosos en la provincia de Almería. Los castillos califales se construyeron con la finalidad de defender a las ciudades de los ataques fatimíes. Al-Udri, menciona la existencia de una fortaleza por cada uno de los distritos agrícolas o comarcas. Eran de planta rectangular cuando era posible y cada tramo disponía de torres macizas, rectangulares realizadas con la técnica del tapial. En el siglo X la organización administrativa de Al-Andalus se hace por grandes provincias, dotadas de capital. En cada uno de estos territorios existía un castillo; hisn, según el término más generalizado, que desempeñaba un papel fundamental en esa organización, como centro de defensa de las comunidades campesinas (CRESSIER, 2005: 45-46). Cressier hace una diferenciación entre los castillos rurales de la provincia de Almeria y las grandes fortalezas, como sería el caso de Marchena, situado en el cerro bajo ese mismo nombre en el actual municipio de Terque. Marchena es muy mencionado por las fuentes árabes desde la época califal hasta la nazarí, siendo una de las fortalezas más importantes de la provincia. Desafortunadamente, a consecuencia del terremoto de 1522 , 


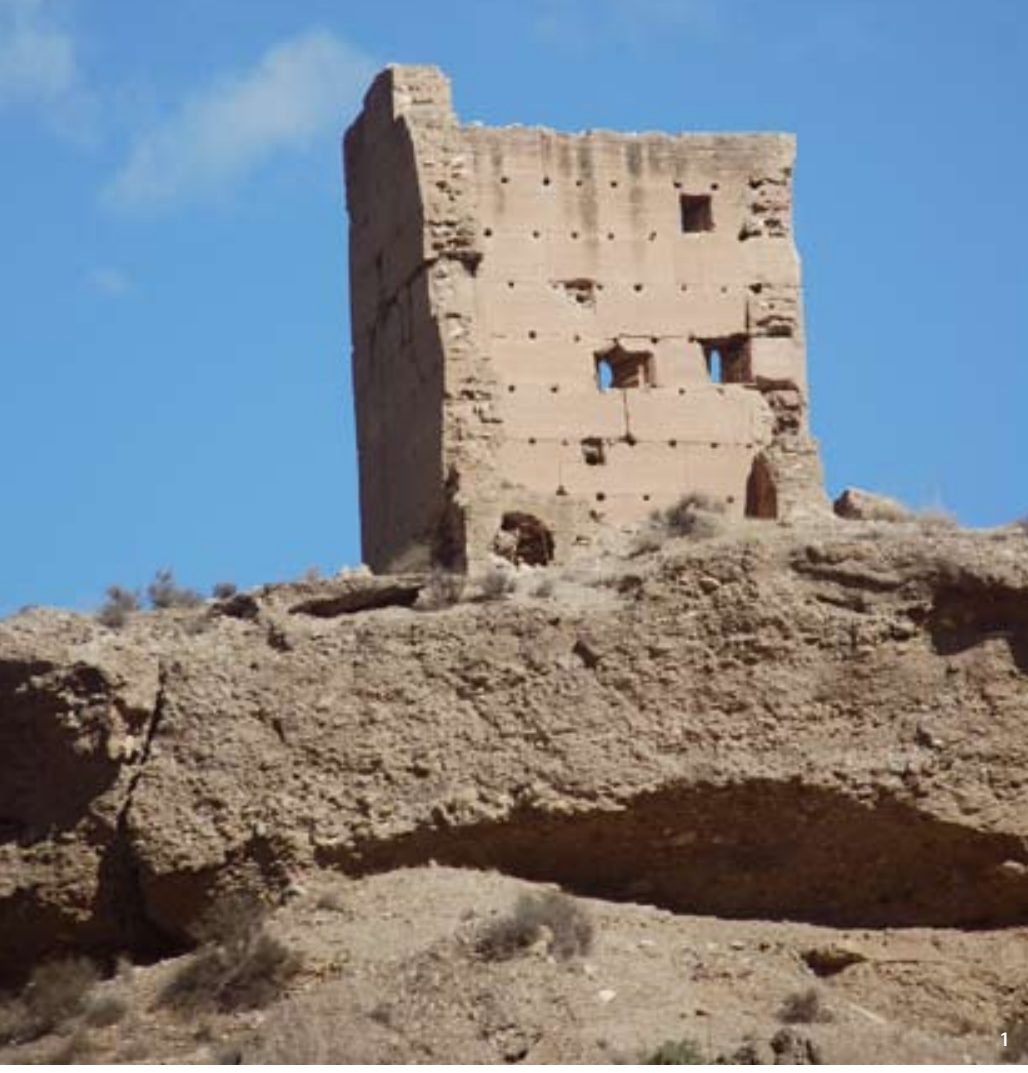

1. Restos del castillejo de Mondújar en el término municipal de Gádor. Foto: María Luisa García Ortega

se destruyó casi en su totalidad, quedando solo, como vestigios de su pasado, varios aljibes y un trozo de muralla.

En la provincia de Almeria los restos de edificaciones defensivas de época califal son escasos, siendo la mayoria de las murallas obra de Jayrán, rey taifa del siglo XI. En el pueblo de Gádor, en la comarca del bajo Andarax, se conservan los restos del castillejo o fortaleza de Mondújar, localizada al lado del camino GranadaAlmería. Se trata de un típico castillo rural del siglo XI levantado para proteger a la población. Se construyó sobre la antigua fortaleza romana, es de planta rectangular irregular, casi cuadrada. Consta de dos torres macizas en las esquinas y torres rectangulares y huecas intermedias. La fábrica de la base es de mampostería con mortero de cal, y alzado de tapial. Actualmente, se encuentra muy deteriorado, casi ruinoso (imagen 1).

Uno de los castillos más interesantes de la provincia que además ocupa una situación privilegiada es el de Tabernas, del que no se encuentra nada escrito hasta época nazarí. Se rodeaba de una
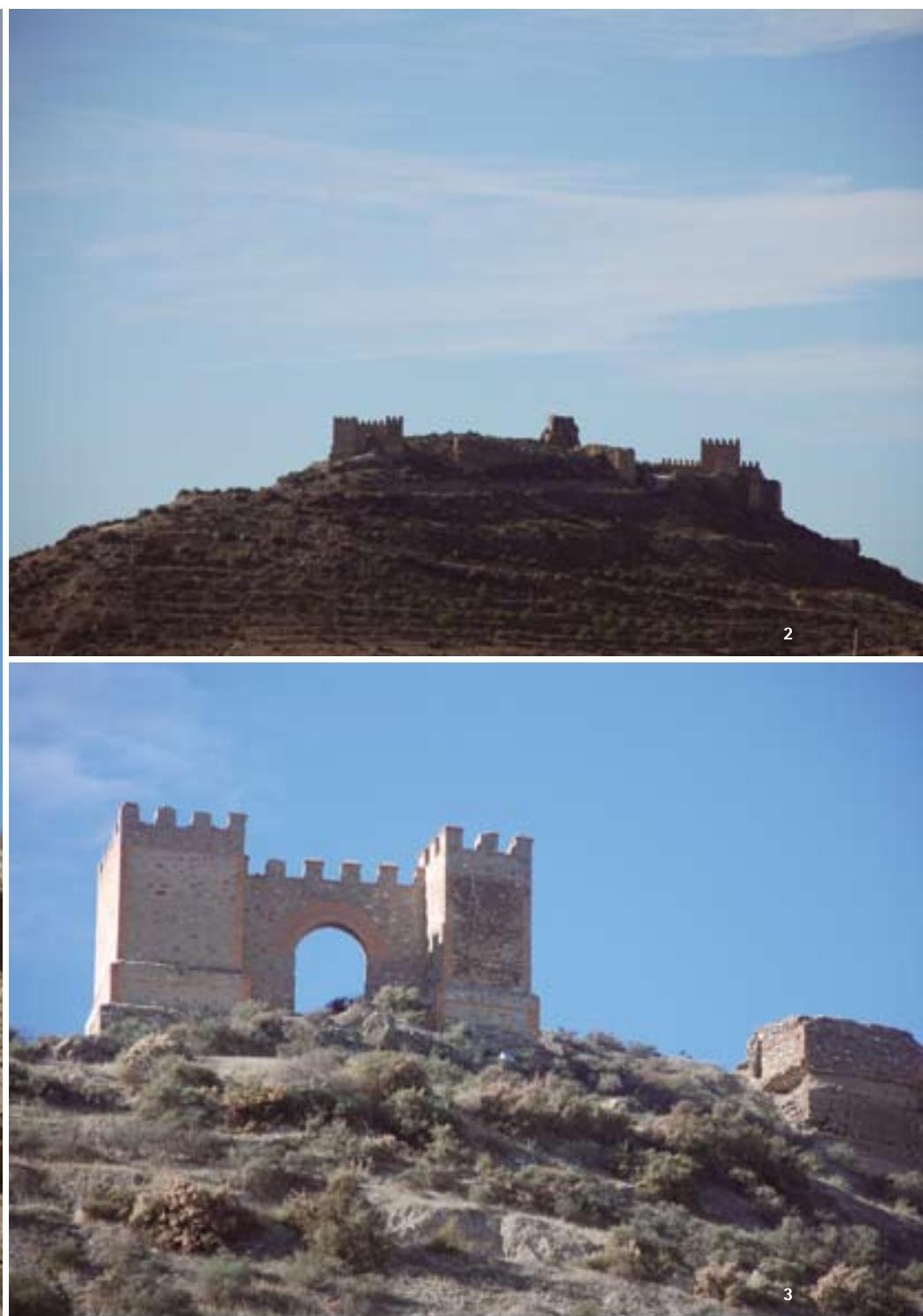

2. Castillo de Tabernas desde la carretera. Frente oeste.

3. Puerta reconstruida del castillo de Tabernas. Restauración realizada en los años 70 Fotos: María Luisa García Ortega

muralla en la que vivía la población y en él residía el alcaide con su tropa, es por ello que algunos historiadores lo lleguen a calificar de alcazaba. Su situación estratégica, ruta de paso entre el Valle del Andarax y el del Almanzora, y cierre de acceso a la capital por el levante, le permitía resistir asedios prolongados (imagen 2). Tiene planta poligonal alargada, que se adapta a las irregularidades del terreno y ha llegado a la actualidad dividido en dos recintos, separados por un muro de mampostería y una torre artillera semicircular de inicios del siglo XVI. Una de las partes del recinto sirvió de lugar de residencia y la otra se utilizó para uso militar. La entrada, franqueada por dos torres, fue reconstruida en los años 70 (imagen 3). Presenta un patio interior, planteado en dos periodos distintos, el último cristiano. Del siglo XI son las trece torres de tapial, rectangulares y salientes, en su mayoría huecas en altura. Se observan restos de una posible torre albarrana que protegería el área habitada inmediata al avanzar ladera abajo desde el extremo oeste, acabando en otra torre. Esta modificación posterior al siglo XII, parte de una gran torre situada al sur que fue totalmente reconstruida en 1985 (imagen 4). El área poblada se extiende 


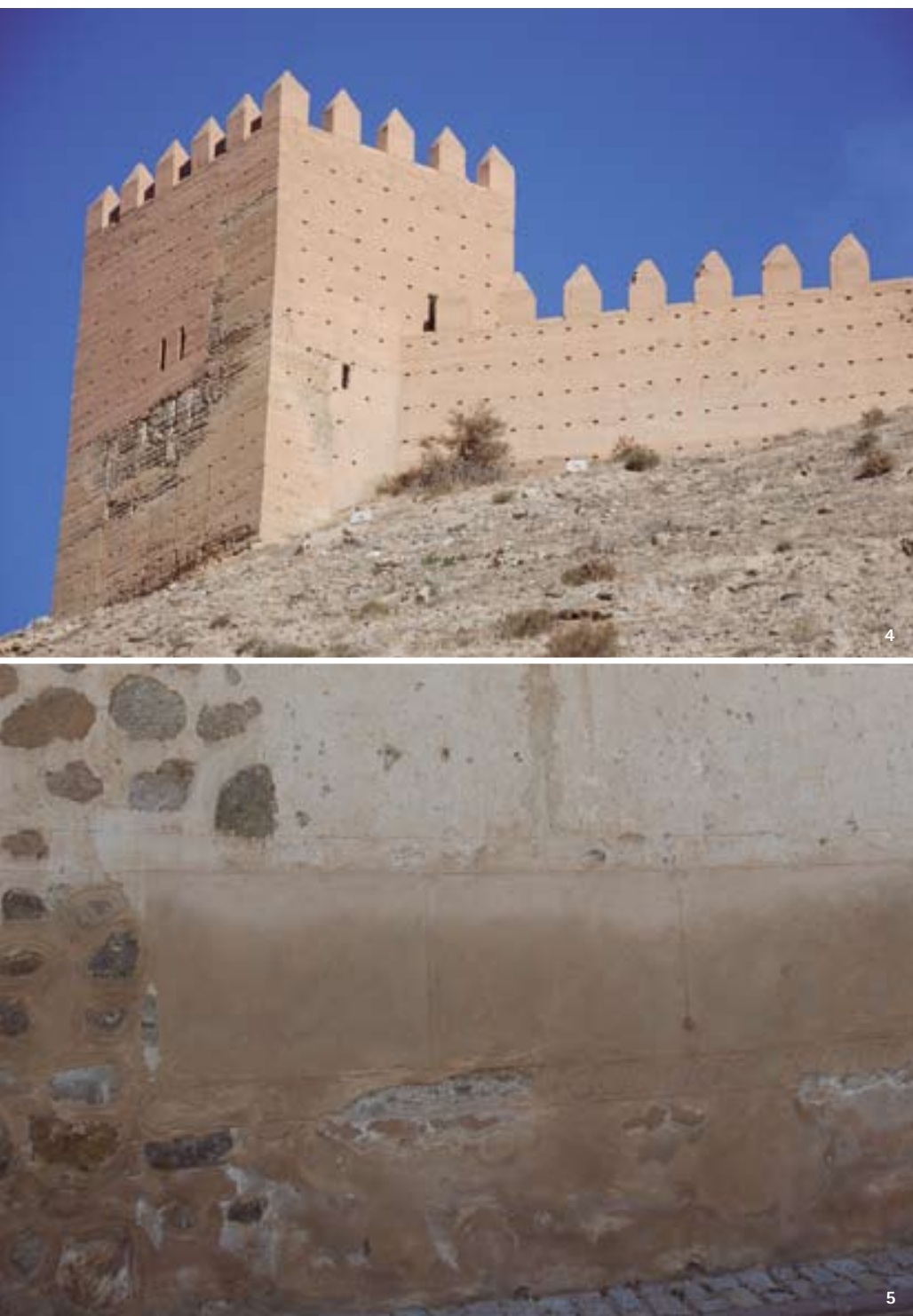

4. Torre y muralla reconstruidas del castillo de Tabernas. Restauración realizada en el año 1985.

5. Detalle de la restauración en la torre de Santa Fe de Mondújar Fotos: María Luisa García Ortega

unas 2 hectáreas, protegida por una muralla de tapial con torres, que se encuentra muy mal conservada, e incluso afectada por un aterrazamiento para repoblación forestal y apertura del camino de acceso (CARA; RODRÍGUEZ, 1998: 208). Como ocurre con los edificios que han sufrido adaptaciones a los diferentes periodos históricos, presenta variedad de materiales de construcción: tapial en los elementos de origen árabe y mampostería, sillares y ladrillo de época cristiana. En 1489 se produce la toma del castillo de Tabernas, junto a otros enclaves estratégicos. El terremoto de 1522 causó graves daños, y posteriormente ante la conflictividad morisca, Felipe II ordenó abrir unos portillos en las torres y muros para inutilizarlo. En el siglo XVII este castillo perdió importancia, al igual que sucedió con muchas otras fortalezas contemporáneas, llegando al siglo XIX en un lamentable estado, agravado por los destrozos sufridos en la guerra de la Independencia. Actualmente presenta un estado de conservación desigual, desde la completa ruina a partes completamente reconstruidas. En los años 70 se rehizo la puerta oeste con las dos torres que la enmarcan, con materiales de muy mala calidad que se han desprendido en algunas

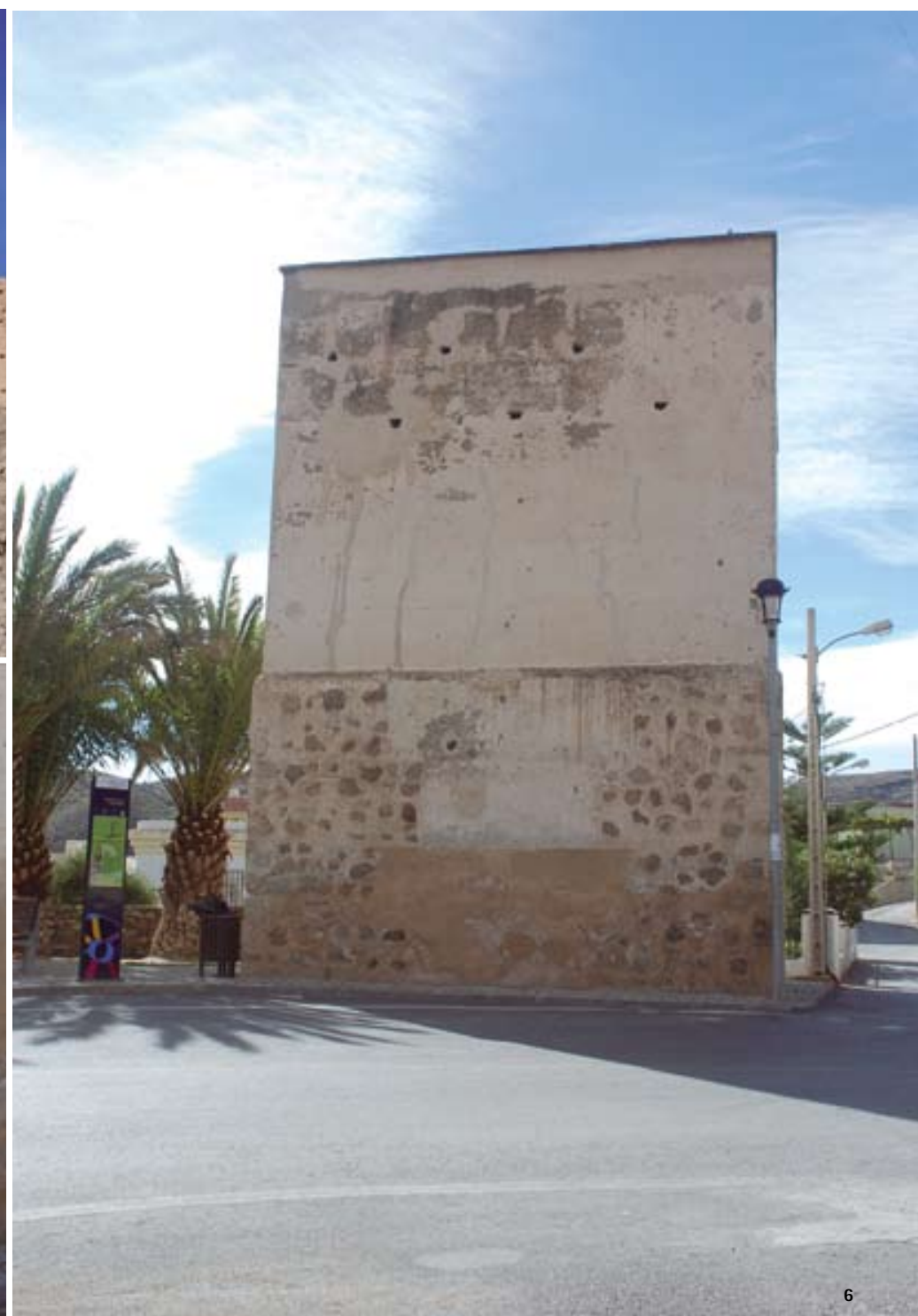

6. Torre de Santa Fe de Mondújar. Foto: María Luisa García Ortega
La degradación de este patrimonio es bastante elevada debido al propio fin para el que fue concebido pero también por haber sido sometido a reformas y restauraciones que no han sabido respetar su aspecto original 
zonas, y en 1985 se reconstruyó la torre sur y parte de la muralla aneja. Esta reconstrucción fue bastante desafortunada tanto por el material utilizado, hormigón armado, como por el acabado que se le aplicó, dando un aspecto artificial al conjunto. En cuanto al muro exterior, considerado como parte de la muralla de población, presenta un estado mucho más deteriorado, siendo muy difícil determinar su trazado.

Más al sur de Tabernas, encontramos la fortaleza de Lucainena, población adscrita a la Cora de Bayyanna. Esta villa se encontraba rodeada de una muralla, con seis torres que guardaban a una torre principal en la que se refugiaban los habitantes en los asedios. De ahí el nombre de Lucainena de las Siete Torres, simplificado en nuestros días a Lucainena de las Torres. La fortaleza era un curioso castillo roquero, de planta alargada con torres rectangulares, de poco saliente y un aljibe adosado al muro. Los castillos roqueros son pequeños castillos, con escasa guarnición, apropiados para la vigilancia estratégica de un territorio o camino. Se adaptan a la topografía del terreno y son reocupados en repetidas ocasiones (CARA; SÁNCHEZ; GIL, 2007: 13). De este castillo tan solo se conservan algunos restos y el aljibe.

De época nazari es la torre, que se encuentra en el pueblo de Santa Fe de Mondújar (imagen 6). Se trata, según la división que establece Malpica, de una torre de Alqueria, es decir, un elemento defensivo situado en torno a una o varias alquerias para acoger a la población que no se podía refugiar en los castillos. Estas torres suelen ser cuadradas de varias plantas, a las que se accedia por la primera altura. Es posible que contasen con un pequeño recinto amurallado anejo, para dar cabida a hombres, bienes muebles y ganado. En la torre se podia hallar, si era necesario, una pequeña guarnición (MALPICA, 2002: 35). La de Santa Fe es de dos plantas, con muros y tapia de argamasa y mampostería, construida cuando este pueblo era un arrabal de las alquerias principales. Su función era la vigilancia de las tierras de cultivo y lugar de refugio en momentos de peligro. Presenta un revestimiento blanco de estuco, en la planta superior y en la inferior, la mampostería se deja ver, intercalando entre las piedras el estuco con dibujos incisos que simulan lágrimas. El estado de conservación de esta torre, en general es bueno, ya que fue restaurada en 1985, aunque el criterio seguido en la reintegración del acabado, no ha conseguido un buen resultado, pues se diferencia demasiado del original, imitándose con mala calidad los dibujos incisos e inventando cenefas donde no las habia (imagen 5).

En Almería el ejemplo más significativo de arquitectura defensiva andalusí lo encontramos en las murallas y la Alcazaba de la capital, que es una de las mayores fortalezas que se conservan en la Península Ibérica. Sus casi mil años de historia nos han permitido conocer la evolución experimentada en la arquitectura civil y militar durante la dominación musulmana en Andalucia, así como la evolución de la ciudad. Las alcazabas y murallas urbanas, a diferencia de los castillos, son mecanismos defensivos relacionados con la ciudad. En ellas residía el poder político, pudiendo llegar a ser palacio o sencillamente asiento de este poder o del militar de la ciudad. (MALPICA, 2002: 34). La Alcazaba de Almeria fue una fortaleza militar y al mismo tiempo la sede del gobierno de la ciudad, que contó con el mayor puerto de Al-Andalus del siglo $X$ al XII. Está situada en un cerro aislado, adaptando sus muros a la topografía. Es una sólida y extensa fortaleza con murallas de un metro veinte de anchura y cinco de altura, formando un recinto cerrado sobre si mismo pero conectado con lienzos de muralla, de la Hoya y San Cristóbal, que configuraban la fortificación de la ciudad (imagen 7). La de la Hoya o de Jayrán (1012-1028) une la Alcazaba con el cerro de San Cristóbal y se trata de un lienzo de muralla de tapial, con torres cuadradas. Las murallas del cerro, conocido como Yabal Laham, se componen de una serie de torres de sillarejo de planta circular, adosadas a torres cuadradas y restos de muralla de tapial, que protegen la cortina de la Hoya (imagen 8). La cronología es incierta y se relaciona con la conquista de Almería en la época de Alfonso VII. Según algunos historiadores, estas murallas constituian parte del cerramiento de un posible arrabal del siglo Xl, denominado La cerca de la Almudaina, pero sin embargo, atendiendo a la interpretación de los textos árabes, podría tratarse de un campamento militar construido por los almohades en el año 1157 para conquistar la ciudad a los cristianos que la habian arrebatado hace diez años, por lo que las muralla de San Cristóbal serian del siglo XII (LIROLA, 1992-1993: 8-13). Los materiales se han ido adaptando a cada época, encontramos torres y muros de tapial, que contrastan con los añadidos de sillarejos enripiados de época cristiana. Hay que destacar la puerta de acceso a la Almudaina, con una fachada septentrional de construcción ciclópea con una gran piedra como dintel.

El cerro de la Alcazaba, dada su posición estratégica y de dominio sobre el espacio circundante y el mar, ha sido utilizado desde tiempos muy remotos (imagen 9). Las evidencias más antiguas de su uso son de época romana, aunque no de tipo defensivo. En el año 995, tras el ataque fatimi, Abd al Rahman III mandó construir las murallas, constituyéndose como una ciudadela fortificada. Se perfeccionó todo el conjunto y se engrandeció con Almanzor. En el siglo XI, bajo el reinado taifa de Jayrán se amplia la ciudad con dos nuevos barrios, lo que implicará su amurallamiento. Estos cambios afectan también al interior de la fortaleza que queda dividida en dos recintos. Durante la época taifa se produce además un importante desarrollo de las funciones residenciales y representativas, como se deduce de la descripción que hace AI-Udri del palacio de Al-Mutasim (CARA, 2005: 113). En el siglo XII, se produce la conquista cristiana de Alfonso VII, tras la cual los almohades reconquistan la ciudad, que pasó posteriormente a pertenecer al reino nazari de Granada. En esta época la Alcazaba sufrió numerosas remodelaciones, tanto en zonas de uso público como en las murallas, que son restauradas. Pero la principal transformación se produce tras la conquista cristiana de los Reyes Católicos en 1489, quienes construyen un castillo en lo que hoy constituye el tercer recinto, además de completar el sistema defensivo con el levantamiento de una serie de baluartes en zonas estratégicas del conjunto. En el siglo XVI la población se resguarda en el segundo 

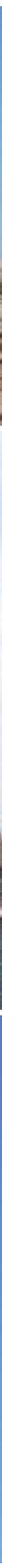

7. Muralla de Jayrán y la Alcazaba de Almería. Foto: Francisco Arias

8. Murallas del cerro de San Cristóbal de Almería. Vista desde la Alcazaba.

Foło: Francisco Arias

9. Conjunto Monumental de la Alcazaba de Almería. Frente sur.

Foto: María Luisa García Ortega

10. Torre del Saliente y muralla norte de la Alcazaba de Almería.

Foto: María Luisa García Ortega

11. Primer tramo de la muralla sur de la Alcazaba de Almería y torre del Saliente.

Restauraciones de finales de los 70 y principios de los 80 .

Foto: María Luisa García Ortega 


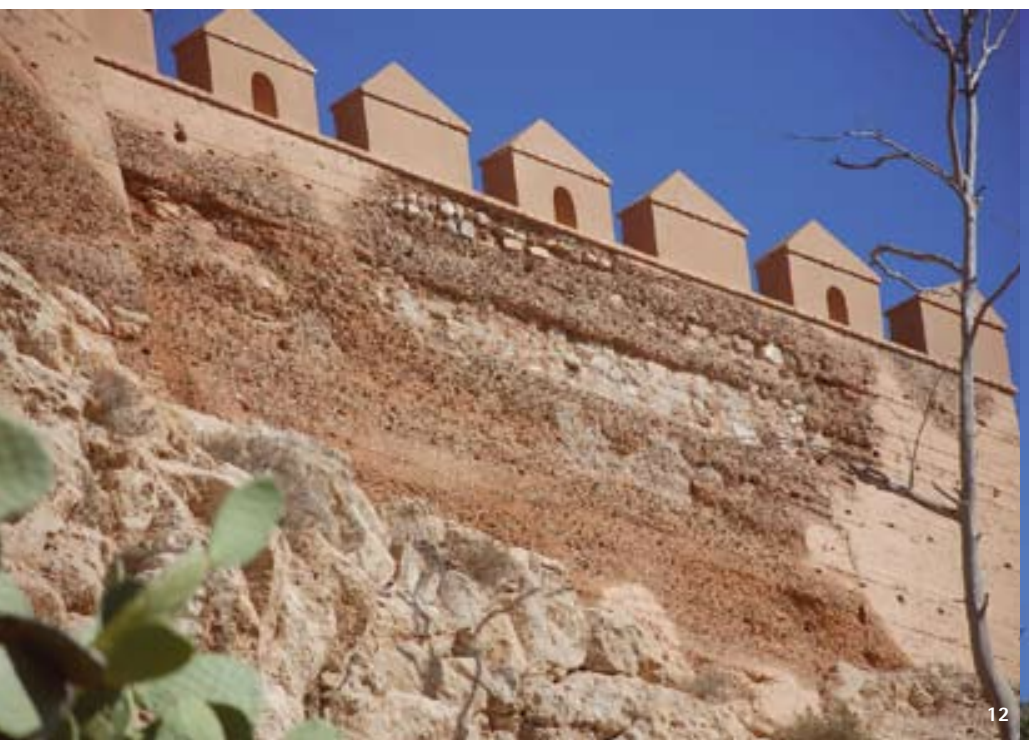

12. Detalle de deterioros en la muralla sur del Conjunto Monumental de la Alcazaba. Tramo restaurado en los años 80. Foto: María Luisa García Ortega

recinto, instalándose algunos baluartes artilleros, que se multiplican durante los siglos XVII al XIX, según las necesidades defensivas de la población. Asi en el siglo XIX la fortaleza siguió cumpliendo una menguada función defensiva hasta su abandono total a partir de la entrada de las tropas francesas en 1810. A partir de ahi perdió su valor militar y fue victima de un paulatino expolio, desapareciendo incontables elementos de su pasado. A esto se suma los destrozos ocasionados por los terremotos que se sucedieron durante varios siglos, en los años 1487, 1522, 1658 y 1804, que influyeron notablemente en la desaparición del palacio.

En cuanto a los materiales de construcción utilizados en la Alcazaba, destaca el uso de la técnica de tapial desde época califal hasta periodo nazarí, en el primer y segundo recinto, mientras que el castillo cristiano del tercero, está constituido a base de sillería de piedra. El acabado de las murallas era de enlucido blanco de cal, del que quedan algunos restos originales en la muralla norte (imagen 10). Lógicamente tantos siglos de existencia han dado lugar a numerosas reformas y reparaciones en todas las épocas, por lo que encontramos muchos huecos rellenos con ladrillos o mamposteria, en ocasiones con el objeto de consolidar los muros, asi como paños enfoscados con revoco liso, a veces, y otras rayado imitando tapial.

En 1931, gracias al impulso del arquitecto Torres Balbás, la Alcazaba es declarada Monumento Histórico Artístico, pero no es hasta los años 40 cuando se comienza a excavar y restaurar el monumento. El encargado de las labores de restauración hasta los años 70 fue el arquitecto granadino Francisco Prieto Moreno, alumno de Torres Balbás, quien reconstruyó varias zonas del Conjunto al estilo de la Alhambra. En 1976 se construye la torre del Saliente, en el primer recinto, sobre la antigua batería del mismo nombre, transformando el perfil visual del Monumento (imágenes 10 y 11). Posteriormente, de 1979 a 1986, se llevan a cabo varias intervenciones por el Ministerio de Cultura, entre las que destacan

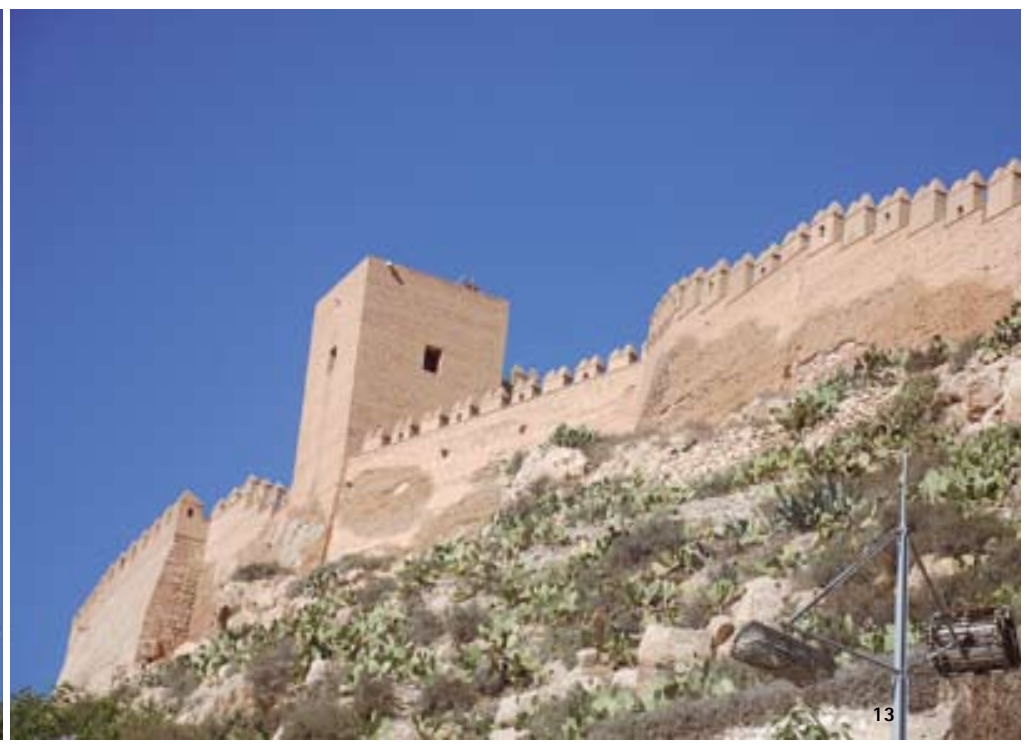

13. Muralla sur del Conjunto Monumental de la Alcazaba. Tramo restaurado en los años 80 , del primer y segundo recinto. Deterioros y manchas de humedad. Foto: María Luisa García Ortega

la restauración de la escalinata del primer recinto y la restauración de la muralla sur. El arquitecto encargado de estos proyectos fue Roberto Puig Álvarez, quien también intervino en la consolidación de las murallas de San Cristóbal de 1979 a 1980, y más tarde, en 1985, será el responsable de la restauración del castillo de Tabernas. En la muralla sur de la Alcazaba, la restauración se fue acometiendo por fases. La primera fase consistió en la consolidación del tramo desde el Saliente a la torre de los Espejos, mediante mampostería asentada sobre cimentación de hormigón armado, y rejuntado con mortero de cal y cemento coloreado (imagen 11). Las demás fases abarcaron la restauración de los tramos de muraIla restantes hasta el tercer recinto, reconstruyéndose los merlones, que no existían, a lo largo de todo el lienzo. En esta ocasión el material utilizado para la consolidación y reconstrucción fue hormigón coloreado, ofreciendo el mismo mal resultado que en el caso de Tabernas, con el agravante de que, debido a su impermeabilidad, se están acrecentando los problemas de humedad que sufre esta muralla, y que se vislumbran en forma de grandes manchas y pérdidas de material (imágenes 12 y 13 ).

En 1989, la Consejería de Cultura de la Junta de Andalucía asume la titularidad y gestión del monumento, creándose el Conjunto Monumental de la Alcazaba. En los años 90 tiene lugar otra intervención de gran impacto, que consistió en la remodelación de los jardines del primer recinto mediante un sistema de aterrazamiento similar al existente en el valle de la Hoya. Desde entonces y hasta ahora han continuado las labores de investigación en el Conjunto, a través de excavaciones tanto en el enclave palacial del segundo recinto, como en otros espacios, a la vez que se han acometido pequeñas obras de conservación, estando en espera de poder desarrollar grandes proyectos de restauración, con criterios normalizados, en todo el Conjunto y sobre todo en sus murallas, cuyo estado de conservación es, como se ha visto en algunas zonas, bastante preocupante. 


\section{El Museo de Almería}

El Museo de Almería es una institución histórica que desde 1933 ha acogido el patrimonio almeriense. Diversas circunstancias la han dotado de una personalidad propia, una identidad que se ha ido fraguando de manera paralela a las vicisitudes que ha sufrido la propia institución. De manera oficial nace con el Decreto de Creación del Presidente de la República, Niceto Alcalá Zamora y Torres, el 28 de marzo de 1933. Después de quince años de cierre en la década de los 90 el centro siguió funcionando, atendiendo a investigadores y gestionando administrativamente la sede, pero será en 2006 cuando arranca una segunda etapa de servicios al público. La propia naturaleza de su colección refleja la diversidad y riqueza del patrimonio arqueológico y etnológico almeriense, asi como las circunstancias que han dado identidad a los fondos del Museo.

La remodelación de su sede ha dotado al edificio de una presencia urbana mucho más accesible y cercana. No sólo el desarrollo arquitectónico del edificio, sus formas y volúmenes sorprenden en el entorno de la ciudad, también lo hace la plaza de acceso al Museo que se ha convertido en un espacio de ocio, a la vez que escenario de múltiples actividades del centro. Destaca en el proyecto museológico actual el nuevo giro dado a la institución. Este cambio pasa por concebir una exposición singular. El edificio acoge una exposición permanente que desarrolla de manera monográfica el periodo histórico documentado en el sureste de la Península lbérica durante el III y II milenio a. de C. Las sociedades de los Millares y el Argar son las auténticas protagonistas del desarrollo expositivo del Museo. La presentación incorpora recursos museográficos interactivos, audiovisuales y un concepto muy novedoso: la creación artística contemporánea al servicio de la interpretación histórica. Soluciones arriesgadas que hacen de la presentación arqueológica un ámbito de innovación en materia museográfica. Sin duda se trata de un recurso hasta ahora muy poco utilizado, pero que supone un cambio importante en la manera de contar la historia.

En los pocos años que el centro lleva abierto al público en esta segunda etapa es necesario resaltar cómo se ha conseguido la implantación del proyecto del Museo de Almería y su reflejo en la ciudad. Todo ello ha sido posible a través del apoyo de la Dirección General de Museos y de la Delegación Provincial de la Consejería de Cultura de la Junta de Andalucía, órganos de gestión que han sabido respaldar las iniciativas del centro. Asociaciones, proyectos expositivos, actividades didácticas... son numerosos los ámbitos de actuación en los que el Museo desarrolla su papel como punto de gestión y de proyección cultural.

En el campo de las exposiciones temporales los criterios aplicados para la realización de las mismas siempre han tenido en cuenta las carencias de la ciudad, tanto a nivel de espacios para albergar determinadas muestras artisticas, como a nivel de apoyo para la producción de exposiciones con altos valores de rentabilidad social. Como ejemplos son significativos algunas muestras como la producción propia "Del Rito al Juego"; o la realizada para conmemorar el 50 aniversario de la obra literaria de Juan Goytisolo

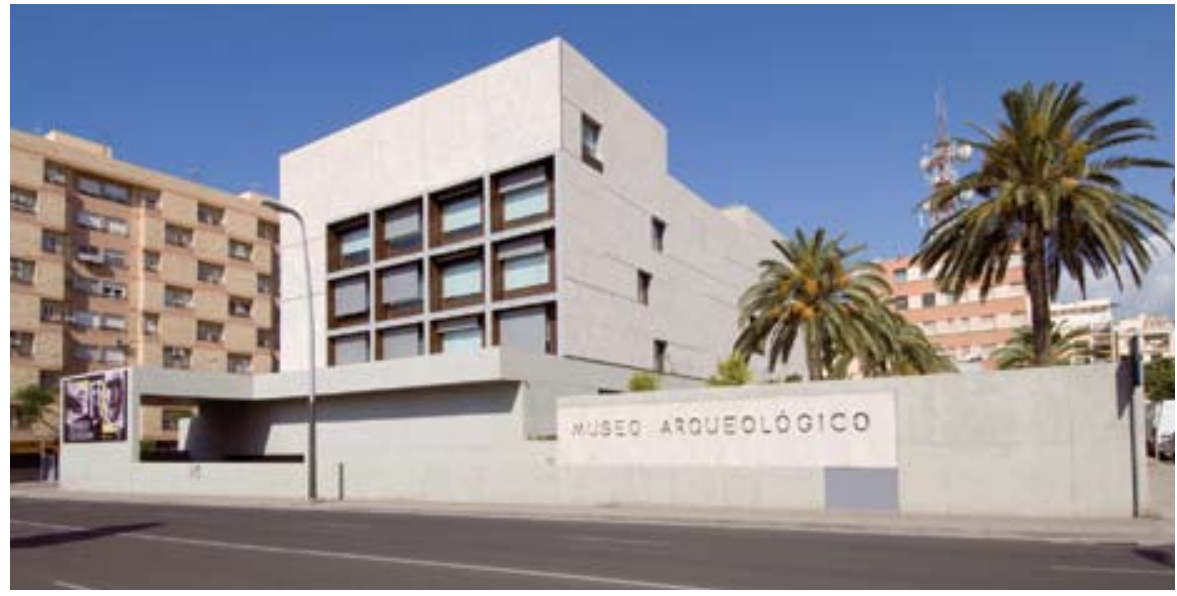

Edificio del Museo de Almería. Foto: Juan Carlos Cazalla, IAPH

"Campos de Nijar. Morada sin memoria", o la exposición "Federico Castellón. De Almería a Nueva York", proyectos que han sabido integrar investigación, didáctica y fomento del patrimonio cultural.

De forma paralela, se ha continuado con el desarrollo de los trabajos técnicos propios del ámbito del Museo: la restauración de piezas, la investigación en materia museológica, o la actual apuesta por el desarrollo de las áreas de reserva visitables. Este último proyecto pretende completar la oferta del Museo de Almeria, dotando al centro de una parte del espacio orientado a profesionales en un lugar pensado para la colaboración con grupos de trabajo en materia de investigación. Y por otra presentar de manera didáctica gran parte de los fondos que forman parte de la colección del Museo y que por problemas lógicos de espacio y de contexto expositivo no se encuentran en la exposición permanente. Se pretende además multiplicar el espacio de almacenaje y potenciar el uso de estas dependencias ofertando nuevos itinerarios para público especializado y visitas concertadas. El centro en su reciente andadura se ha posicionado como lugar de referencia para actividades culturales y agente catalizador de iniciativas de diversa indole. En esta línea, el hecho de presentar programación de la Filmoteca de Andalucía, o la colaboración con la Excma. Diputación de Almería en su Festival Anual de Cortometrajes, sitúa al Museo como organismo colaborador de una de las facetas más creativas que ha tenido y que se proyecta hoy para Almería: el cine. Siguiendo esta trayectoria es importante mencionar también las muestras fotográficas dedicadas al Grupo Afal, o la dedicada a la conmemoración de los 25 años de Fotoperiodismo en Almería.

Otro de los rasgos definitorios de la institución es la inserción en el tejido asociativo; desde la reapertura al público el Museo acoge iniciativas provenientes de la Asociación Luis Siret de Amigos y Amigas del Museo de Almería. Esta asociación en sus planteamientos recoge diversas propuestas que toman forma en un desarrollo paralelo junto al centro. Es importante destacar la colaboración por ejemplo en la programación para mostrar la pieza del mes, o los talleres didácticos de otoño en 2009; actividades caracteri- zadas por la creatividad y el trabajo en equipo. Otras asociaciones encuentran su apoyo para determinadas actividades en el Museo, algunas de ellas son: Capacitarte, El teléfono de la Esperanza, Amnistía Internacional o Proyecto Hombre. Unido a esta trayectoria, es imposible dejar de mencionar el apoyo a la educación formal y a los profesionales de la enseñanza. De manera permanente se establece un programa de visitas guiadas con escolares. Numerosos centros solicitan la asistencia en visitas concertadas con el equipo del Museo, trabajo que realizan el grupo de auxiliares de instituciones culturales apoyado en vigilantes de sala y personal técnico del Área de Difusión.

En el ámbito científico y de investigación, es importante destacar el I Ciclo de Cine Histórico, el III Encuentro de Mujeres y Arqueología, o el proyecto futuro de Congreso Internacional de Arqueología de la Construcción, dedicado a las canteras del Mundo Antiguo, proyectos que vinculan el Museo al ámbito de la investigación y al territorio. Por último mencionar el incremento de las cifras de público desde la reapertura en marzo de 2006. Si el año 2006 se cerró con 39.737 visitantes, 2007 con 42.286 y 2008 con 47.132, las cifras actuales para 2010 aseguran igualmente el incremento para este año. Se trabaja actualmente en la publicación de la guia breve del Museo, cuaderno pedagógico guia del profesor y alumno, y la guía oficial. Es un trabajo en desarrollo que acompañado de las hojas de evaluación y estudios de público oportunos, denotan un permanente empeño en ofrecer al visitante itinerarios y propuestas de su interés. Desde la institución se pretende mantener la apertura al visitante, a la ciudad, pasando por la cercanía y tratando de atender en la medida de lo posible las iniciativas e inquietudes de los sectores educativos y culturales de Almería. Se ha programado el año 2010 con importantes muestras y actividades, esperando garantizar unos estándares de calidad avalados por la trayectoria definida hasta ahora y buscando en todo momento un ocio cultural de calidad.

Ana Dolores Navarro Ortega

Directora del Museo de Almeria 


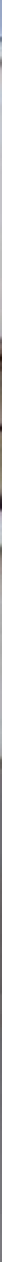

Vista exterior de la galería del colegio Lope de Vega. Foto: Juan Carlos Cazalla, IAPH 


\section{La Ciudad Jardín de Almería. La condición compleja del patrimonio urbano contemporáneo}

Plácido González Martínez, Marta Santofimia Albiñana, Centro de Documentación y Estudios, Instituto Andaluz del Patrimonio Histórico
La Ciudad Jardín de Almería (1940-1947), obra del arquitecto GuiIlermo Langle, surge en la posguerra como experimento residencial destinado a implantar, a las afueras de la ciudad, un nuevo modelo que significase las aspiraciones del Régimen, a la manera de manifiesto dedicado a la última capital andaluza en mantenerse fiel al gobierno de la República. Buscando un "nuevo comienzo" para dar solución al problema de la residencia marginal en la periferia urbana, la Ciudad Jardín se situó al sureste de la ciudad, aislada por el trazado del ferrocarril, constituyéndose como colonia de 245 viviendas organizadas en torno a un espacio central ajardinado que ponía en relación el programa de edificios públicos compuesto por la iglesia, el edificio de servicios municipales, el colegio y el mercado.

Teniendo en cuenta estas aspiraciones de "nuevo comienzo" con las que fue impulsada, nos aproximaremos a la Ciudad Jardín de Almería reconociéndole un carácter complejo heredado de distintas teorias urbanísticas y arquitectónicas surgidas a finales del siglo XIX y comienzos del XX, de las que habremos de seleccionar una serie de valores que constituyen su aportación singular.

En primer lugar, podríamos decir que el proyecto de Langle se nos presenta como un "caballo de Troya" encargado de introducir en el contexto del sur peninsular una nueva forma de habitar procedente de la modernidad industrial europea; la ciudad jardin propuesta por Ebenezer Howard en 1898, un modelo que tuvo que adaptar sus caracteristicas espaciales, económicas y sociales a las singularidades culturales del lugar. Como respuesta a la cuestión dolorosa de la vivienda obrera en la ciudad industrial occidental, las teorias de la ciudad jardin pasaron a la historia como el primer modelo de organización urbana provisto de conciencia global, que pretendía universalizar al grueso de la sociedad moderna las ventajas de la vida en contacto con la naturaleza que hasta entonces sólo habian conocido los sectores más aventajados de la burguesía.

Sin embargo, y como demostraron las propias realizaciones de Howard en los casos pioneros de las ciudades de Letchworth (1903) y Welwyn (1919), la ambición del alcance de las ideas de la ciudad jardin fue en detrimento de la integridad de su concepto y a favor del abandono de ciertas metas que se había marcado originariamente. Así ocurrió también en España, donde a pesar de la vinculación de la ciudad jardin a los programas de casas baratas, los esfuerzos que impulsaron al estudio de las relaciones entre espacios públicos y privados, del control de la densidad edificatoria, de la cualificación ambiental a través de la vegetación y de la racionalización de la vivienda fueron destinados a un segmento privilegiado de la burguesía, que aprovechó el paradigma del aislamiento para constituir archipiélagos aislados del resto de la ciudad.

Al mismo tiempo, y también desde sus orígenes, el propósito de autonomía productiva y social que pretendia conseguir Howard con la ciudad jardín a través de la presencia de la industria, la asociación con la agricultura y la separación respecto a la metrópolis, dio paso a un modelo sucedáneo, el del suburbio jardin, desarrollado en Inglaterra por Raymond Unwin tras su experiencia en Letchworth, en el que las intuiciones ambientales de la relación entre arquitectura y naturaleza terminaron prevaleciendo sobre los fundamentos sociales y económicos originales.

El modelo de la ciudad jardín se planteaba a nivel teórico como paradigma urbano de la individualidad, renunciando inicialmente a definir modelos residenciales o estilos arquitectónicos. Por el contrario, en su puesta en práctica, y como muestra la obra de Langle, hubo de materializarse adaptándose a un proceso de homogeneización propio de los nuevos ritmos de producción de la vivienda, convertida en la principal cuestión a resolver en la arquitectura del siglo XX. Siguiendo los ejemplos pioneros alemanes de las grandes Siedlungen promovidas durante la República de Weimar, así como en los ejemplos españoles de las colonias de Parque Residencia (1931-1934) y EI Viso (1933-1936), construidas durante la Segunda República en Madrid, la arquitectura de la ciudad jardín de Almería se sometió a un proceso de depuración. Estas tres cuestiones: ciudad jardin, suburbio jardin, y colonias, hubieron de ponerse en juego para la Ciudad Jardín de Almería en un contexto de cambio radical como era la España de 1940: el ses- 
go politico de los promotores de las ciudades colonias, impulsadas desde el socialismo durante la República, pasó a situarse en el extremo opuesto. La mentalidad conservadora y sus paradigmas de la unidad ideológica, la independencia cultural, la recuperación de las aspiraciones imperialistas, la autarquía económica, etc., constituyeron el filtro por el cual debieron pasar y reformularse.

Teniendo en cuenta todos estos condicionantes previos en la génesis y realización del proyecto de Langle, la Ciudad Jardin que conocemos por la documentación fotográfica de la época presenta una imagen utópica de espacios ajardinados en contacto con una arquitectura preparada para disolverse en una naturaleza aún en sus brotes, de aislamiento físico de la colonia respecto a la ciudad, de homogeneidad tipológica, constructiva y cromática de la arquitectura, de especial cuidado en las transiciones entre los espacios públicos y los privados..., escena que con el paso del tiempo fue sucumbiendo a la dinámica del crecimiento urbano que la engulló y a las nuevas aspiraciones de los propietarios que la transformaron.

Ante esta situación de cambio acelerado, aparecen inevitablemente cuestiones de trascendencia patrimonial relativas a su esencia: a la hora de enfrentarnos a una muestra de patrimonio urbano contemporáneo en la que confluye una selección de valores tan complejos, ¿es posible considerar cada uno de estos valores por separado? ¿Podemos reclamar a la Ciudad Jardín de Almería fideli- dad a las aportaciones de Howard, Unwin y los defensores del modelo de las Siedlungen? ¿Podríamos, en tal caso, considerar justificadas las adaptaciones realizadas por los sucesivos propietarios sobre las viviendas de Langle, en coherencia con el paradigma de la individualidad de las teorias de Howard, a pesar de que nunca estuvieron presentes en el proyecto?

En este sentido, podriamos entenderlo como un hojaldre de valores, en el que las texturas se superponen, y es precisamente en los matices que marcan el tránsito de unas capas a otras donde se revela la riqueza patrimonial del conjunto de la Ciudad Jardín hoy día. Cabe considerar entonces a la Ciudad Jardín de Almería en términos de autonomía urbana en la línea del suburbio jardín inglés del que Hempstead (1909), obra de Raymond Unwin, sirve de claro ejemplo; o resaltando la preocupación por los aspectos ambientales heredados de las teorias de Howard; o bien, señalando la apuesta por la unidad estética, tipológica y formal como conceptos heredados de las Siedlungen, donde la homogenización jugaba un papel fundamental. Formando parte de esta lectura integral y compleja, habremos de referirnos a estas tres cuestiones, insistiendo en su aportación para la configuración de una identidad para la ocupación urbana de la periferia almeriense.

Comenzaremos por el valor de la autonomía urbana, que es el punto de partida de las teorias de Howard, si bien para la Ciudad Jardin de Almería se manifiesta desprovisto del sentido económi-

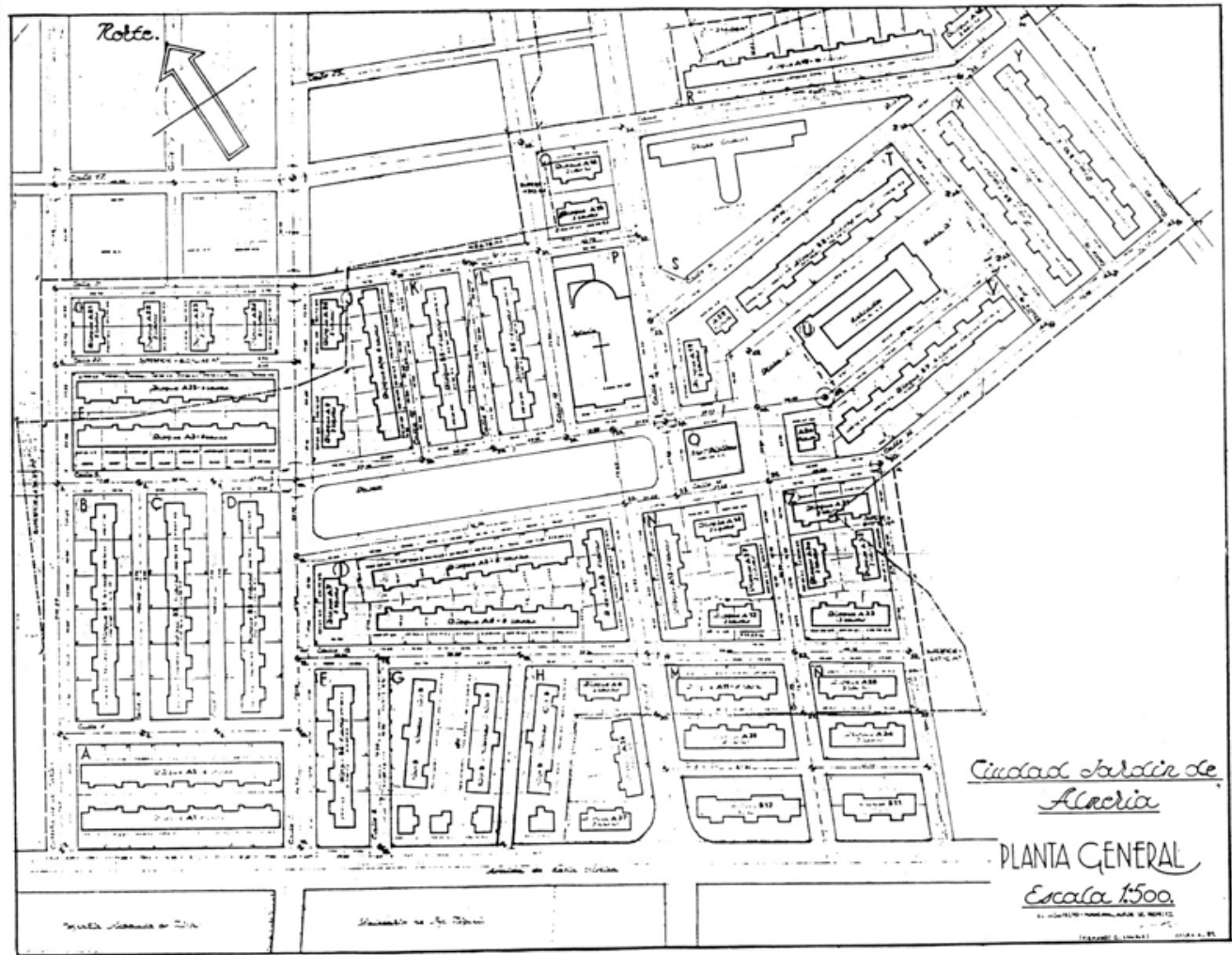


co, para insistir exclusivamente en la creación de un modelo espacial aislado, próximo a la pequeña ciudad que Heinrich Tessenow definió en 1919 para regenerar la vida urbana en la Alemania de entreguerras. La importancia de este referente conservador, en el que la recuperación de la vida comunitaria se confiaba a las certezas de la ciudad preindustrial, se evidencia en la relevancia que toma la iglesia para el proyecto de Langle, entendida como punto de referencia del conjunto respecto a la capital. Desde el acceso privilegiado que se consigue desde la calle de Castilla, la Iglesia de San Antonio de Padua muestra toda su carga simbólica hacia el espacio público central de la ordenación, que no de manera casual recibió el nombre de la Plaza de España.

Este espacio, de planta rectangular alargada, se ofrece como lugar de encuentro comunitario, y muestra al edificio de servicios públicos como remate en su lado este, sirviendo de nuevo hito de una manera secundaria respecto a la iglesia. Se establece, por tanto, una jerarquia clara en las dotaciones del barrio: la iglesia y el edificio de servicios públicos ofrecen la cara más representativa de la Ciudad Jardín, mientras que los otros dos equipamientos, como son el magnífico edificio racionalista del colegio Lope de Vega y el mercado, se integran en el tejido residencial, a una escala más modesta y doméstica.

La creación de ciertas escenas identitarias: con los valores de estabilidad que proporcionaba la iglesia; los de educación que transmitía el colegio; de intercambio económico a pequeña escala que incorporaba el mercado y la existencia de un poder político, como ofrecia el edificio administrativo, resultaba prioritaria. Por esta razón, se debería considerar que, por encima de las necesarias adaptaciones que se imponen a estos edificios, como ha sido el caso de la escuela y sus sucesivas ampliaciones, es necesario mantener la integridad de otras presencias y su vinculación originaria al resto de la Ciudad Jardin; hecho que no ha ocurrido en el mercado y el edificio público, hoy día desaparecidos y sustituidos por piezas y usos que no han participado de los valores del conjunto.

En segundo lugar, podríamos identificar valores ambientales en la escala más menuda del proyecto, en la relación que se pretende entre calle y casa, que ofrece la oportunidad de experimentar consiguiendo interesantísimos resultados. El estudio de los espacios ajardinados de la Ciudad Jardín de Almería saca a relucir la trascendencia de los elementos de cierre de las parcelas: muretes, pilastras, celosías de hormigón armado y vegetación, que gracias a su transparencia y su baja altura permiten una relación fluida entre el espacio público y el espacio privado. De igual forma, la importancia del control de las secciones del viario, del cuidado en la elección de especies vegetales y su disposición en los espacios abiertos, ofrece claves para entender la aportación del proyecto de Langle a nivel paisajístico.

Esto se hace extensivo a la cuidada volumetria de los distintos tipos de viviendas desde el proyecto, que procuraban la ruptura de la calle corredor, la reducción de altura en las esquinas merced a la creación de porches abiertos a los jardines, así como terrazas

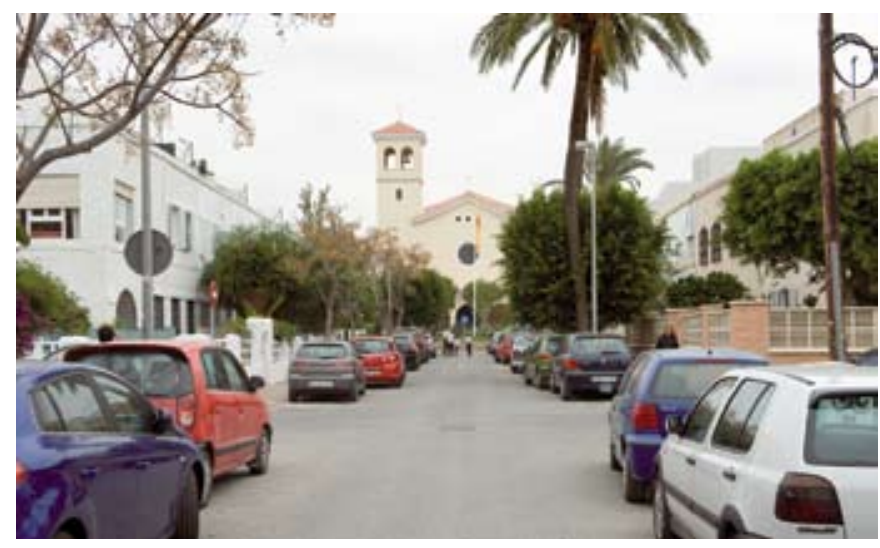

Vista de la Iglesia San Antonio de Padua desde la calle Castilla. Foto: Juan Carlos Cazalla, IAPH

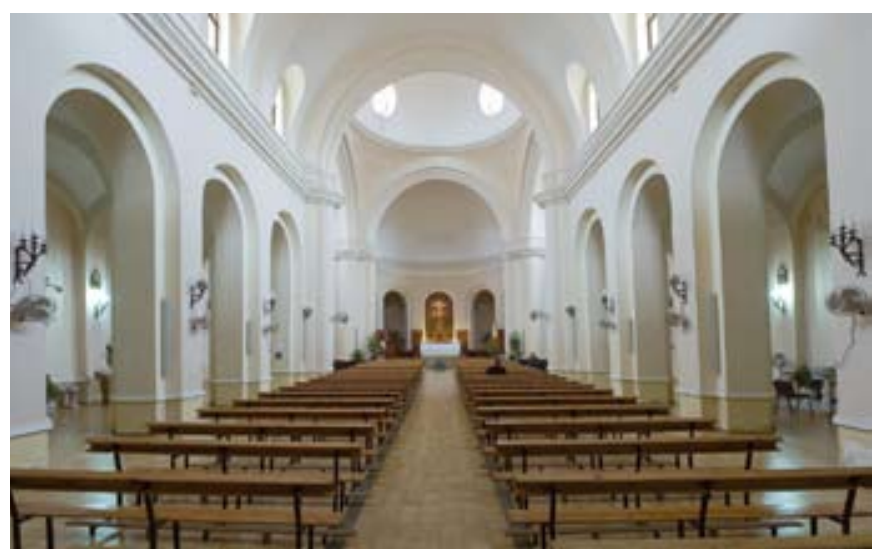

Arcos de la nave principal de la Iglesia de San Antonio de Padua. Foto: Juan Carlos Cazalla, IAPH

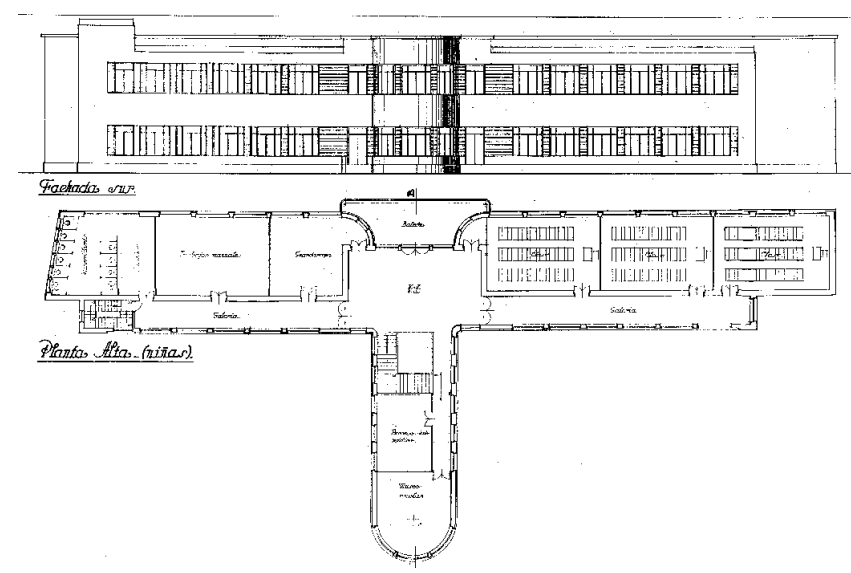

Planta alta y fachada sur del colegio Lope de Vega. Fuente: Archivo Municipal de Almería

que esponjaban la relación entre el espacio construido y el espacio libre. Gracias a los esfuerzos compositivos por conseguir variedad en los tipos de vivienda, y organizar de manera casual los volúmenes edificados, el efecto final fue indudablemente pintoresco, traduciendo para la modernidad las búsquedas que la arquitectura suburbana del siglo XIX habia hecho desde lo vernacular, entendido como lo azaroso y lo desordenado.

Lamentablemente, encontramos que las operaciones puestas en juego por Langle para conseguir la calidad ambiental han tenido una evolución completamente azarosa: Ios tipos han sido alterados hasta hacerse en algunos casos irreconocibles, incorporándo- 


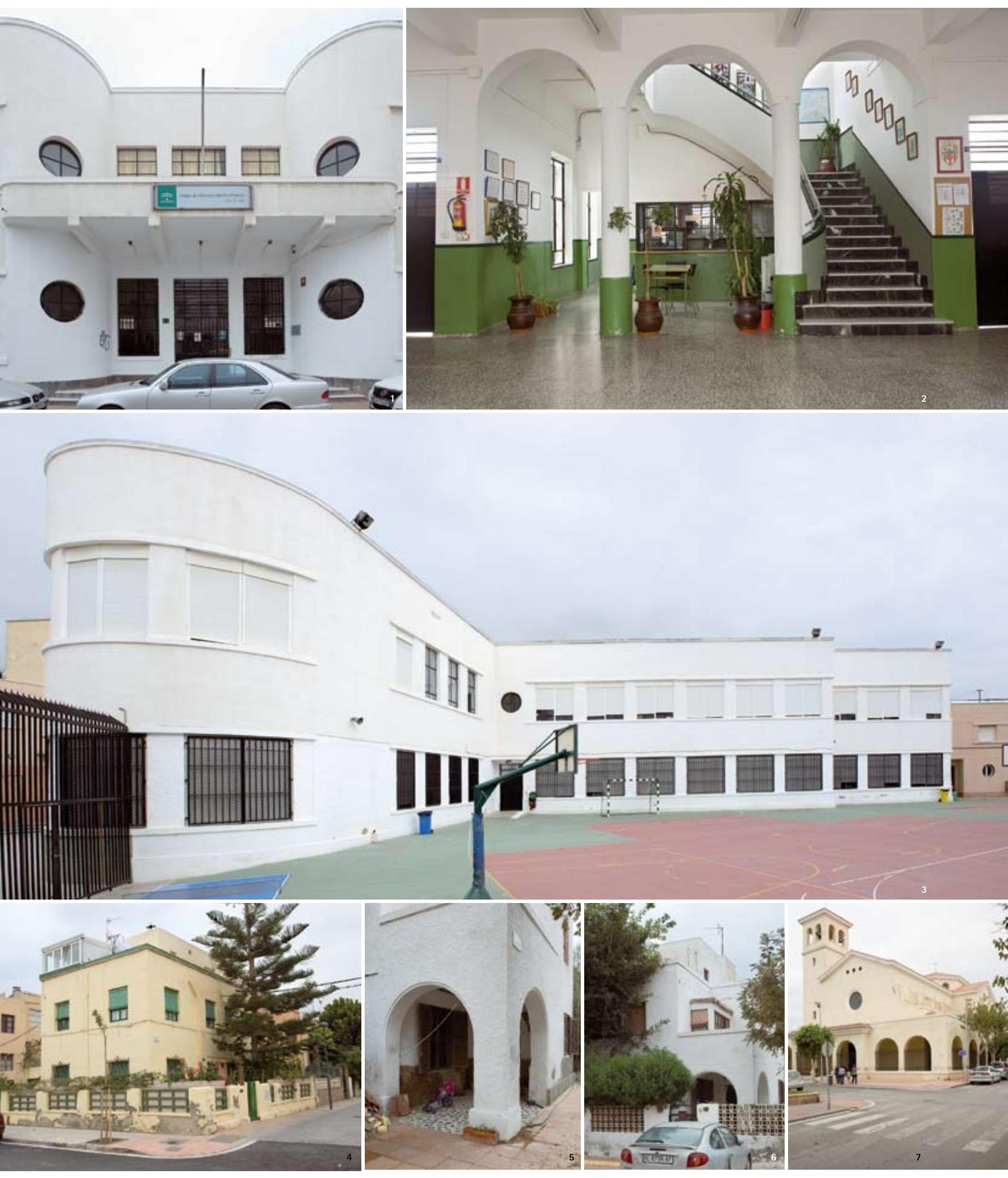


se al espacio habitable de las viviendas los elementos singulares de las azoteas y los porches, derivando en una imagen hinchada y compacta de lo que fue en otro tiempo una arquitectura modesta y porosa. De igual manera ha ocurrido con los elementos que estaban destinados a reforzar el sentido identitario como es el caso de los cierres de parcelas, que han sido en su mayor parte sustituidos y elevados, perdiendo transparencia y evidenciando asi la tendencia a la fortificación del espacio privado en la ciudad contemporánea.

En tercer lugar, nos encontramos con la apuesta que se realizó desde las primeras Siedlungen alemanas por la homogeneización y el mantenimiento de los elementos que, a nivel compositivo, dan unidad al proyecto. Estas variaciones controladas de la arquitectura de la ciudad jardín se correspondian con intentos por homogeneizar el conjunto, que se plasmaban en diversas estrategias de proyecto. Una de ellas era la apuesta por tipificar cuatro modelos de viviendas, que se asociaban en grupos colectivos y unifamiliares. Al mismo tiempo, se trataba de incorporar elementos que diesen unidad al conjunto, como los cierres de parcela anteriormente mencionados, la agrupación horizontal de huecos en la composición de las fachadas y la reivindicación de un elemento característico de la racionalidad mediterránea, tal como la entendian los arquitectos italianos del momento, como es el arco de medio punto, y que sirve para enlazar episodios tan diversos de la ciudad jardín como las viviendas en sus accesos, la iglesia en su porche, y la escuela en su vestíbulo.

Las nuevas necesidades domésticas de los propietarios, acompañadas por el desarrollo económico reciente, han hecho el resto: Ios arcos, que constituian elementos de transición entre los porches y los espacios abiertos, han sido cegados en su mayoria, mientras que en los últimos años hemos asistido a la sustitución de algunos de los tipos de vivienda originales de Langle por nuevos proyectos que se han implantado en el contexto de manera generalmente ajena y autista.

Como conclusión, la Ciudad Jardín de Almeria sigue ofreciendo hoy dia una imagen de relativa integridad, gracias a la generosidad con la que los pioneros de la Ciudad Jardín pusieron las bases de una nueva forma urbana para el futuro. Aun asi, hemos de señalar que las demoliciones y adiciones, cambios de uso y sustituciones, comprometen seriamente la pervivencia de esa mismas ventajas de las que ha disfrutado hasta ahora. Sólo desde la consideración a la integridad material y espacial del conjunto, asi como al mantenimiento del equilibrio social que provenía de la mezcla de usos, podremos seguir hablando de un ejemplo vivo de patrimonio urbano contemporáneo.

\section{En la web}

\section{CONJUNTO MONUMENTAL DE LA ALCAZABA DE ALMERÍA \\ www.juntadeandalucia.es/cultura/ museos/CMAAL}

Portal de Museos y Conjuntos Arqueológicos y Monumentales de Andalucía de la Consejeria de Cultura de Andalucia.

En esta web podrá encontrar información sobre su acceso, oferta de servicios, investigaciones realizadas, ex posiciones, actividades, publicaciones entre otros recursos de interés sobre este Conjunto Monumental.

\section{ASOCIACIÓN CULTURAL TRADICIÓN Y VANGUARDIA DE ALMERÍA.} GUILLERMO LANGLE

www.tradicionyvanguardia.com

langle/guillermolangle.htm

El sitio web de esta asociación dedica todo un monográfico al arquitecto GuiIlermo Langle. Información exhaustiva sobre su vida y obra asi como su bibliografía más destacada.
PORTALMERIAA.COM

www.portalmeria.com

En la sección Conoce Almería de este Portal Web podrá encontrar información sobre los municipios que conforman el valle de Andarax y el campo de Tabernas. Cada municipio ofrece datos sobre su localización, historia, lugares de interés, fiestas y tradiciones, direcciones y enlaces de interés.

\section{MUSEO DE ALMERÍA \\ www.juntadeandalucia.es/cultura/ museos/MAL}

Portal de Museos y Conjuntos Arqueológicos y Monumentales de Andalucia de la Consejeria de Cultura de Andalucía.

Información general, historia del museo, colecciones, publicaciones, actividades y exposiciones son algunos de los recursos a los cuales podrá acceder en este espacio.

\section{ASOCIACIÓN DE AMIGOS DEL FERROCARRIL DE ALMERÍA \\ www.asafal.es}

Asociación dedicada a fomentar y dar a conocer todo lo que conforma el mundo del ferrocarril.

La asociación hace uso de la herramienta Google Earth para representar antiguas líneas de ferrocarril, marcar estaciones, cargadores, minas, etc.

Este sitio web también ofrece un amplio elenco de imágenes así como enlaces relacionados con el mundo del ferrocarril en el ámbito nacional e internacional.

\section{RUTA PAISAJES DE CINE \\ www.paisajesdecine.com}

Web dedicada a mostrar la ruta Paisajes de cine elaborada por la Diputación de Almería.

Esta ruta se desarrolla en el desierto de Tabernas y Sierra Alhamilla y recorre los escenarios más emblemáticos en los que se rodaron dos famosas películas: La muerte tenía un precio e Indiana Jones y la última cruzada.

\section{PLATAFORMA SOLAR DE ALMERÍA} www.psa.es

Sitio web de la Plataforma Solar de Almería ubicada en el desierto de Tabernas. El mayor centro de investigación solar de Europa.

Este proyecto del Ministerio de Ciencia e Innovación pertenece a la Red de Espacios de Divulgación Científica y Técnica de Andalucía.

\section{PATRIMONIO INDUSTRIAL EN ANDALUCIAA ORIENTAL}

www.patrimonioandaluz.com

Esta web pretende crear un catálogo on-line de los principales elementos de patrimonio industrial de las provincias de Almeria, Granada y Jaén, para contribuir a la divulgación de sus valores arquitectónicos, culturales y etnográficos. De forma novedosa, se incluye una sección que recoge la localización exacta de los elementos en forma de POIS (Puntos de Interés en formato GPS). 
se al espacio habitable de las viviendas los elementos singulares de las azoteas y los porches, derivando en una imagen hinchada y compacta de lo que fue en otro tiempo una arquitectura modesta y porosa. De igual manera ha ocurrido con los elementos que estaban destinados a reforzar el sentido identitario como es el caso de los cierres de parcelas, que han sido en su mayor parte sustituidos y elevados, perdiendo transparencia y evidenciando asi la tendencia a la fortificación del espacio privado en la ciudad contemporánea.

En tercer lugar, nos encontramos con la apuesta que se realizó desde las primeras Siedlungen alemanas por la homogeneización y el mantenimiento de los elementos que, a nivel compositivo, dan unidad al proyecto. Estas variaciones controladas de la arquitectura de la ciudad jardín se correspondian con intentos por homogeneizar el conjunto, que se plasmaban en diversas estrategias de proyecto. Una de ellas era la apuesta por tipificar cuatro modelos de viviendas, que se asociaban en grupos colectivos y unifamiliares. Al mismo tiempo, se trataba de incorporar elementos que diesen unidad al conjunto, como los cierres de parcela anteriormente mencionados, la agrupación horizontal de huecos en la composición de las fachadas y la reivindicación de un elemento característico de la racionalidad mediterránea, tal como la entendian los arquitectos italianos del momento, como es el arco de medio punto, y que sirve para enlazar episodios tan diversos de la ciudad jardín como las viviendas en sus accesos, la iglesia en su porche, y la escuela en su vestíbulo.

Las nuevas necesidades domésticas de los propietarios, acompañadas por el desarrollo económico reciente, han hecho el resto: Ios arcos, que constituian elementos de transición entre los porches y los espacios abiertos, han sido cegados en su mayoria, mientras que en los últimos años hemos asistido a la sustitución de algunos de los tipos de vivienda originales de Langle por nuevos proyectos que se han implantado en el contexto de manera generalmente ajena y autista.

Como conclusión, la Ciudad Jardín de Almeria sigue ofreciendo hoy dia una imagen de relativa integridad, gracias a la generosidad con la que los pioneros de la Ciudad Jardín pusieron las bases de una nueva forma urbana para el futuro. Aun asi, hemos de señalar que las demoliciones y adiciones, cambios de uso y sustituciones, comprometen seriamente la pervivencia de esa mismas ventajas de las que ha disfrutado hasta ahora. Sólo desde la consideración a la integridad material y espacial del conjunto, asi como al mantenimiento del equilibrio social que provenía de la mezcla de usos, podremos seguir hablando de un ejemplo vivo de patrimonio urbano contemporáneo.

\section{En la web}

\section{CONJUNTO MONUMENTAL DE LA ALCAZABA DE ALMERÍA \\ www.juntadeandalucia.es/cultura/ museos/CMAAL}

Portal de Museos y Conjuntos Arqueológicos y Monumentales de Andalucía de la Consejeria de Cultura de Andalucia.

En esta web podrá encontrar información sobre su acceso, oferta de servicios, investigaciones realizadas, ex posiciones, actividades, publicaciones entre otros recursos de interés sobre este Conjunto Monumental.

\section{ASOCIACIÓN CULTURAL TRADICIÓN Y VANGUARDIA DE ALMERÍA.} GUILLERMO LANGLE

www.tradicionyvanguardia.com

langle/guillermolangle.htm

El sitio web de esta asociación dedica todo un monográfico al arquitecto GuiIlermo Langle. Información exhaustiva sobre su vida y obra asi como su bibliografía más destacada.
PORTALMERIAA.COM

www.portalmeria.com

En la sección Conoce Almería de este Portal Web podrá encontrar información sobre los municipios que conforman el valle de Andarax y el campo de Tabernas. Cada municipio ofrece datos sobre su localización, historia, lugares de interés, fiestas y tradiciones, direcciones y enlaces de interés.

\section{MUSEO DE ALMERÍA \\ www.juntadeandalucia.es/cultura/ museos/MAL}

Portal de Museos y Conjuntos Arqueológicos y Monumentales de Andalucia de la Consejeria de Cultura de Andalucía.

Información general, historia del museo, colecciones, publicaciones, actividades y exposiciones son algunos de los recursos a los cuales podrá acceder en este espacio.

\section{ASOCIACIÓN DE AMIGOS DEL FERROCARRIL DE ALMERÍA \\ www.asafal.es}

Asociación dedicada a fomentar y dar a conocer todo lo que conforma el mundo del ferrocarril.

La asociación hace uso de la herramienta Google Earth para representar antiguas líneas de ferrocarril, marcar estaciones, cargadores, minas, etc.

Este sitio web también ofrece un amplio elenco de imágenes así como enlaces relacionados con el mundo del ferrocarril en el ámbito nacional e internacional.

\section{RUTA PAISAJES DE CINE \\ www.paisajesdecine.com}

Web dedicada a mostrar la ruta Paisajes de cine elaborada por la Diputación de Almería.

Esta ruta se desarrolla en el desierto de Tabernas y Sierra Alhamilla y recorre los escenarios más emblemáticos en los que se rodaron dos famosas películas: La muerte tenía un precio e Indiana Jones y la última cruzada.

\section{PLATAFORMA SOLAR DE ALMERÍA} www.psa.es

Sitio web de la Plataforma Solar de Almería ubicada en el desierto de Tabernas. El mayor centro de investigación solar de Europa.

Este proyecto del Ministerio de Ciencia e Innovación pertenece a la Red de Espacios de Divulgación Científica y Técnica de Andalucía.

\section{PATRIMONIO INDUSTRIAL EN ANDALUCIAA ORIENTAL}

www.patrimonioandaluz.com

Esta web pretende crear un catálogo on-line de los principales elementos de patrimonio industrial de las provincias de Almeria, Granada y Jaén, para contribuir a la divulgación de sus valores arquitectónicos, culturales y etnográficos. De forma novedosa, se incluye una sección que recoge la localización exacta de los elementos en forma de POIS (Puntos de Interés en formato GPS). 


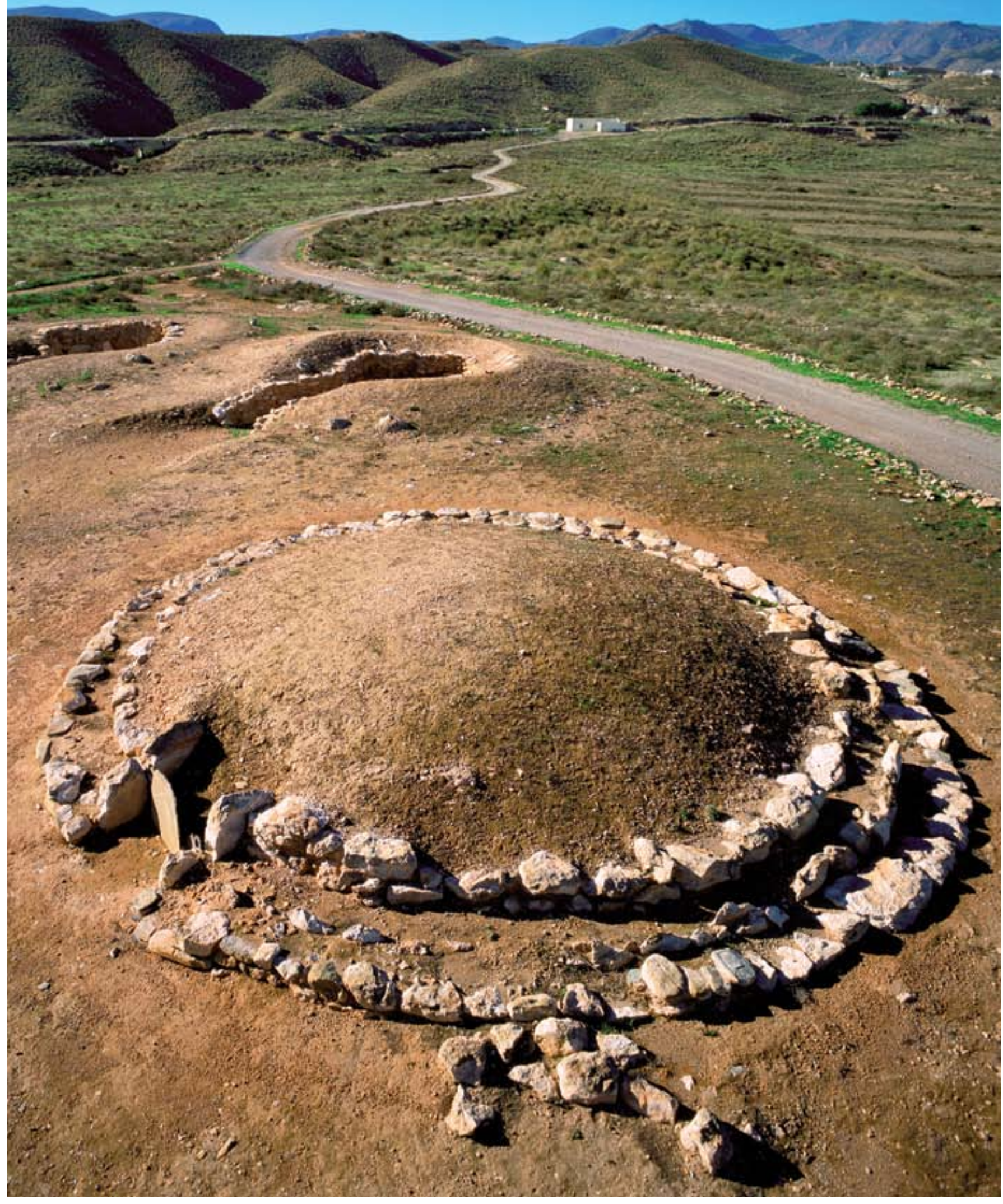

Sepulturas de cámara circular de Los Millares. Foto: Miguel Ángel Blanco de la Rubia. Fuente: Consejería de Cultura de la Junta de Andalucía 


\section{Los Millares y su dominio sobre el valle del Andarax}

Fernando Molina González, Juan Antonio Cámara Serrano, Dpto. de Prehistoria y Arqueología, Universidad de Granada
El medio ambiente del sureste, actualmente árido, ha sido considerado por diversos autores como un elemento determinante en el desarrollo de las sociedades de esta región entre el Neolítico Reciente y el Calcolítico al obligar a una serie de cambios tecnológicos y sociales destinados a facilitar el asentamiento humano. Además, a la hora de valorar los condicionantes del medio sobre las actividades humanas, y especialmente sobre las actividades agropecuarias, también se ha planteado la escasez de tierra arable en esta región, dada la extensión de áreas de fuerte pendiente. En cualquier caso tanto la pérdida de suelo en áreas elevadas como la disminución de las precipitaciones, y sobre todo de la humedad, son fenómenos relativamente recientes unidos a la deforestación, y aunque las oscilaciones climáticas han existido en el pasado no se puede trasladar a la Prehistoria Reciente un ambiente árido similar al actual.

Los análisis paleoambientales realizados a partir del proyecto Millares han demostrado un ambiente más húmedo que el actual, aunque a partir del 4000 a. de C. se tiende a una disminución de las precipitaciones, con una mejora relativa entre el 3300 y el 2200 a. de C. Durante todo este tiempo el valle del Andarax ofrecía un paisaje de tipo mediterráneo con mayor cobertura vegetal en las zonas más elevadas, donde el pinar sustituía a las encinas, y con bosques-galeria de especies caducifolias en torno a los cursos de agua, algunos de los cuales, como el Andarax, debieron ser permanentes y junto a los que vivian animales como las nutrias, galápagos, ratas de agua y diversas anátidas, como el ánade real y el ánsar careto (PETERS; DRIESCH, 1990; RODRÍGUEZ; VERNET, 1991; ARAUS et ál., 1997).

Entre el VI y el V milenio a. de C., durante el Neolítico, la movilidad estacional de las comunidades humanas configura en el Andarax pequeños asentamientos con una densidad baja de restos, habitados episódica y periódicamente, junto con la ocupación de algunas cuevas, que por mucho tiempo se han considerado características y exclusivas del periodo. Estos yacimientos al aire libre se suelen situar en áreas altas desde las que controlaban visualmente su territorio de explotación, como es el caso del al- jibe de Lubrin (Tabernas) (ALCARAZ et ál., 1994). Poco a poco, el aumento de la estabilidad acentuó la necesidad de remarcar la propiedad de las diferentes partes del territorio de explotación, utilizándose para ello las tumbas megalíticas desde la transición al IV milenio a. de C. Se trata de sepulcros bajo túmulo de cámara circular o poligonal sin corredor de acceso, destinados al enterramiento de pocos individuos.

A partir del IV milenio a. de C. la población se sedentariza como resultado de la consolidación de la economía agropecuaria y la restricción de la movilidad, a excepción de pequeños grupos humanos que acompañaban estacionalmente los rebaños. Se construyen las primeras aldeas situadas en áreas favorables, de transición entre ecosistemas, con fácil acceso al agua y que permiten, todavía, un control del entorno, aspectos que ejemplifica en el Andarax el asentamiento del cerro de la Chinchilla en Rioja y, sobre todo, determinados yacimientos del pasillo de Tabernas, junto al arroyo de los Molinos y sus afluentes. Las causas de este proceso se deben buscar en la necesidad de mano de obra para las labores agrarias (especialmente en los momentos de la cosecha), la competencia con otras comunidades y la vinculación interpersonal resultado de los primeros procesos de acumulación de riqueza (pecuaria).

El yacimiento de Los Millares se funda hacia el 3300 a. de C. (M0LINA; CÁMARA, 2005), cuando los procesos de diferenciación entre asentamientos estaban ya marcándose, lo que puede explicar sus excepcionales características. Ya desde su inicio presenta tres líneas concéntricas de muralla, que cierran las dos mesetas más internas de un espolón situado en la confluencia de la Rambla de Huéchar con el río Andarax, junto a la cual la muralla más interna configura una ciudadela en la que una gran cisterna, a la que llegaba un largo acueducto (SIRET, 1893), ayudaba a mantener constante el suministro hídrico para personas y animales.

Desde su fundación, el poblado estaría acompañado por una amplia necrópolis de sepulcros tumulares (SIRET, 1893; LEISNER; LEISNER, 1943; ALMAGRO; ARRIBAS, 1963), que se extendia por la meseta más externa, amplia y elevada del espolón, actuando 

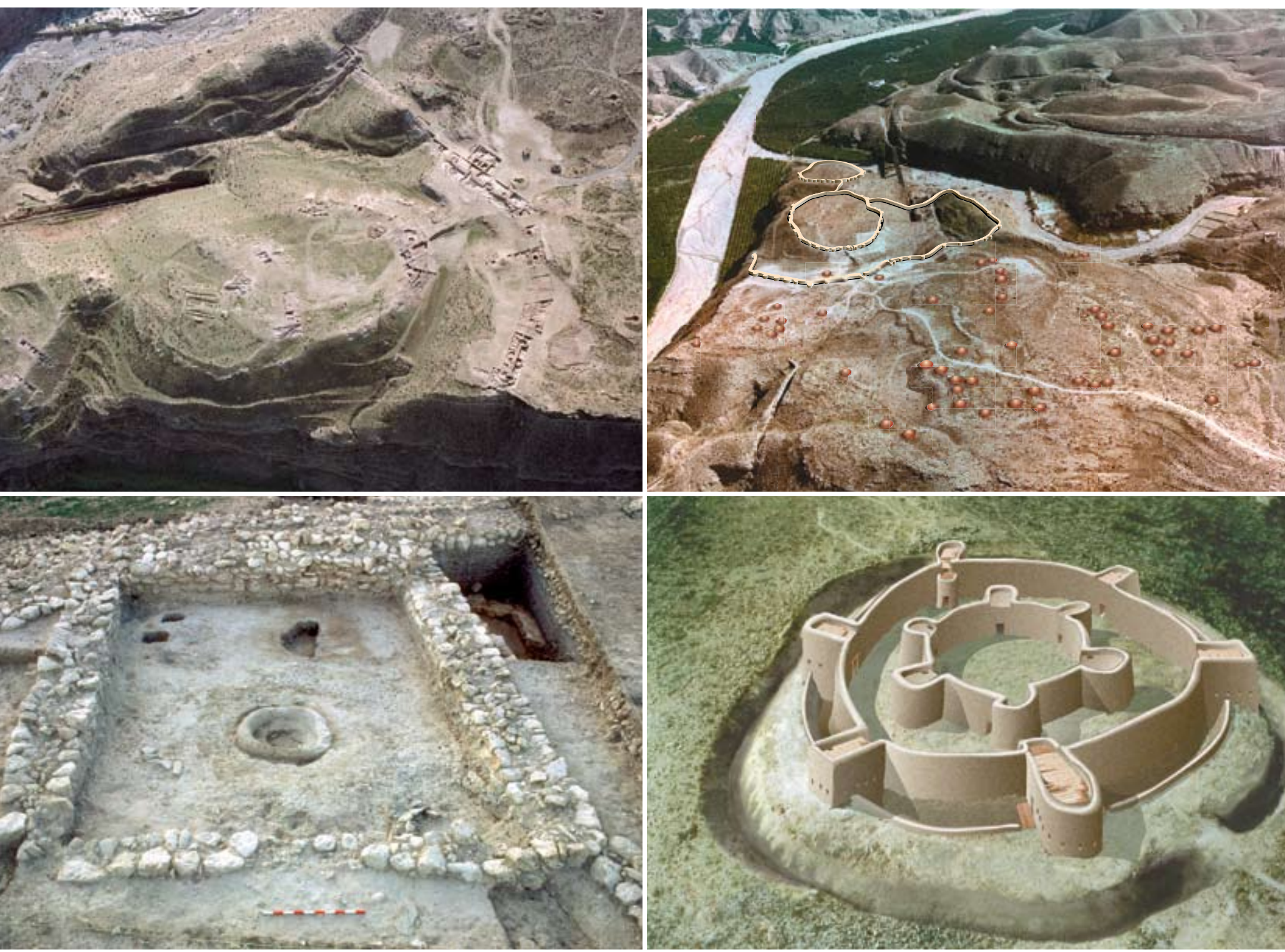

Vista aérea del poblado de Los Millares. Fuente: Paisajes Españoles Taller metalúrgico de Los Millares. Fuente: Dpto. de Prehistoria, Universidad de Granada

Los Milllares con la reconstrucción de las líneas de fortificación y la necrópolis. Infografía: M. Salvatierra

Reconstrucción del Fortín 1 de Los Millares. Infografía: A. Luque

como una línea de defensa ritual exterior. La necrópolis está compuesta fundamentalmente por tumbas que presentan corredor de acceso, segmentado por puertas abiertas en las losas de piedra, y cámara circular de mampostería con zócalos revestidos por lajas de pizarra, cubierta con falsa cúpula (tholoi) o con techumbre plana de materia orgánica. En el pasillo o en la cámara pueden abrirse pequeños nichos laterales para los enterramientos infantiles. El conjunto se cubre con túmulos de tierra y piedras. Al exterior las tumbas poseen un pequeño vestíbulo destinado a la celebración de rituales funerarios. Todos los sepulcros son de uso colectivo y en ellos se llegaron a enterrar un máximo de unos 100 individuos con sus ajuares funerarios. Junto a las tumbas de cámara circular existen 3 tumbas dolménicas que ofrecen técnicas constructivas y ajuares funerarios similares a los de las cercanas agrupaciones megalíticas del piedemonte de la sierra de Gádor.

Hacia el 2800 a. de C. el agregado urbano de Los Millares acrecienta su importancia con la ocupación de parte de la meseta exterior, defendida por una nueva muralla más externa, acompañada de foso, que conserva un perimetro de unos $400 \mathrm{~m}$ y que llega a integrar determinadas sepulturas en su recinto interior. Esta muralla posee una anchura de unos dos metros y presenta a intervalos regulares bastiones semicirculares y torres de planta oval, estando la entrada principal defendida por una gran barbacana.

Aunque las excavaciones en el poblado no han sido muy extensas se han podido documentar diferencias en las dimensiones de las viviendas (más pequeñas en la zona exterior), en los patrones de consumo (con cerdos adultos castrados y bóvidos jóvenes en la ciudadela) (NAVAS et ál., 2008) y en la existencia de edificios especiales (talleres metalúrgicos y gran construcción de planta rectangular situada al interior de la tercera muralla). Estas diferencias sociales ya habian sido sugeridas por el estudio de la necrópolis (CHAPMAN, 1991), donde las sepulturas muestran diferencias en dimensiones, complejidad estructural, emplazamiento y conteni- 

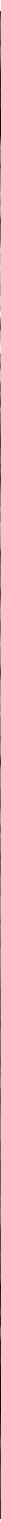

Barbacana de la puerta principal en la muralla exterior de Los Millares. Foto: Migue Angel Blanco de la Rubia. Fuente: Consejería de Cultura de la Junta de Andalucía

Vista aérea vertical de las excavaciones en el Fortín 1 de Los Millares. Fuente: Paisajes Españoles

do, hasta el punto de que las tumbas más ricas se situaban, dentro de cada una de las agrupaciones que se han definido dentro de la propia necrópolis, en la zona más cercana al asentamiento o al camino de acceso a éste (MOLINA; CÁMARA, 2005).

Al menos desde el 2600 a. de C. el sistema defensivo de Los Millares fue completado con dos series paralelas de 13 fortines de diversa complejidad a uno y otro lado de la Rambla de Huéchar (ARRIBAS et ál., 1987). En ellos las actividades domésticas (textiles, por ejemplo.) están ausentes y el almacenaje y procesado de productos alimentarios (grano y sal) supera, con mucho, las necesidades de los residentes. Además se ha determinado la realización de actividades artesanales (en especial la talla de puntas de flecha) que se han relacionado con actividades de iniciación de los jóvenes. Además la función militar queda claramente demostrada no sólo por el emplazamiento y la forma general de esos fortines, algunos como el Fortín 1 verdaderas fortalezas con doble recinto rodeado de fosos, sino por la documentación de saeteras que
Aunque las excavaciones en el poblado no han sido muy extensas, se han podido documentar diferencias en las dimensiones de las viviendas, en los patrones de consumo y en la existencia de edificios especiales 


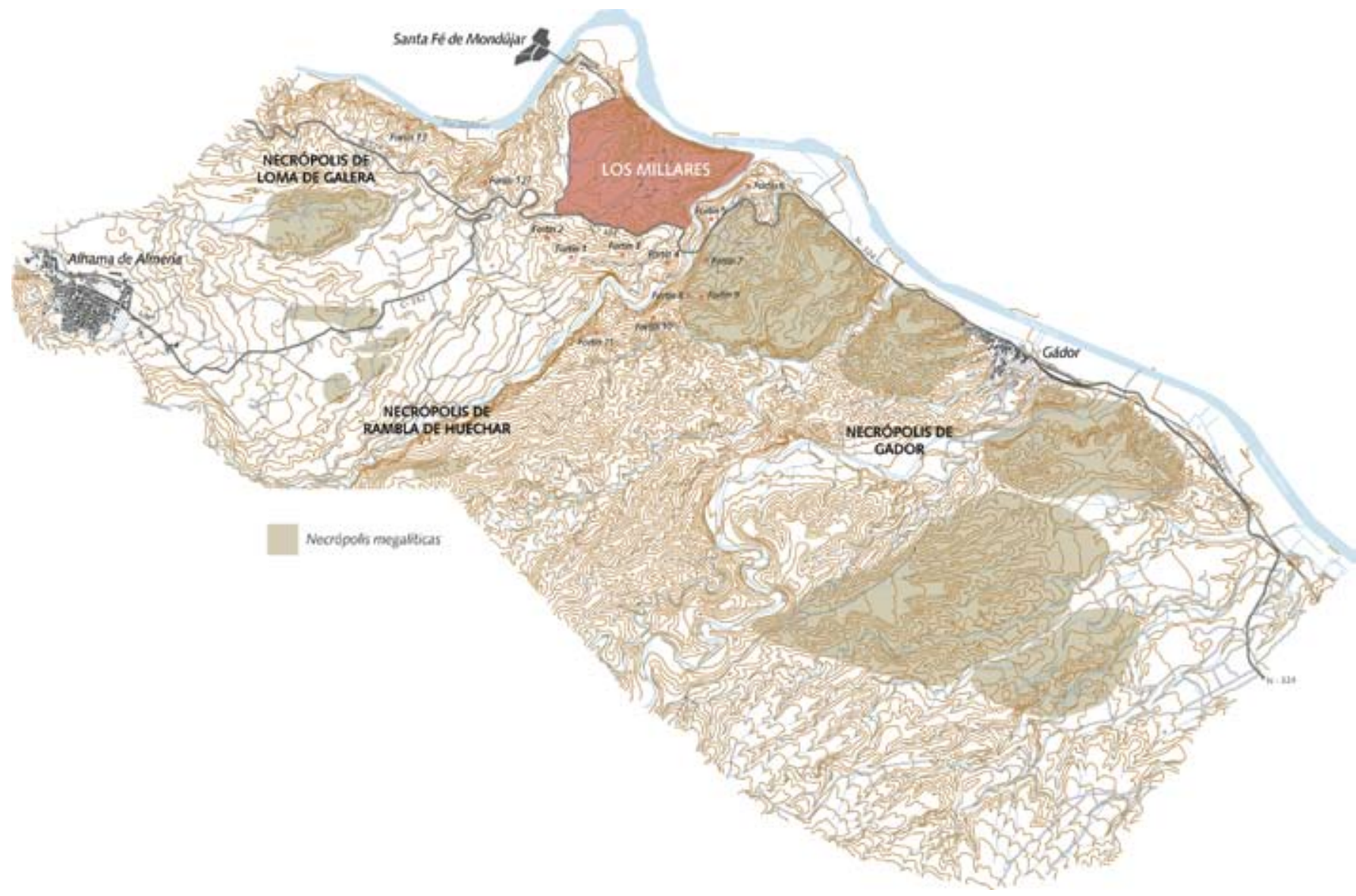

Los Millares y las agrupaciones megalíticas de su entorno. Mapa: Dpto. de Prehistoria, Universidad de Granada

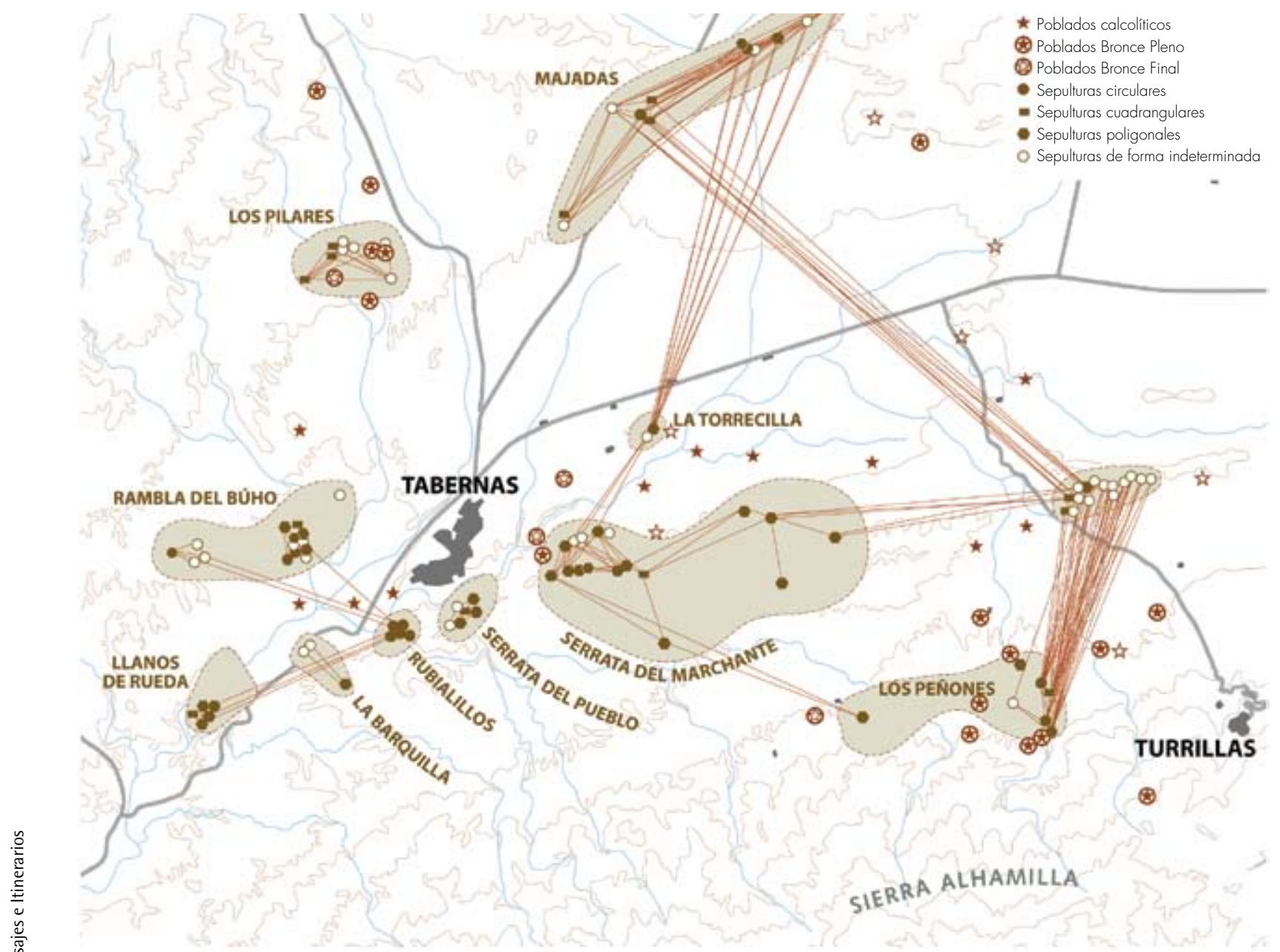

Distribución de yacimientos y visibilidad en el Pasillo de Tabernas durante la Prehistoria Reciente. Mapa: Dpto. de Prehistoria, Universidad de Granada 
atraviesan las paredes de murallas y bastiones cubriendo todos los puntos de acceso y que en el caso del recinto interior de esta fortaleza fueron inutilizadas cuando dejaron de ser funcionales al construirse un nuevo recinto exterior. Además la planificación no sólo incluyó el diseño general del sistema defensivo sino el esquema planimétrico de los fortines, manteniéndose incluso el mismo centro geométrico utilizado para diseñar la muralla exterior (ESQUIVEL; NAVAS, 2005). Los fortines, según las dataciones disponibles, fueron destruidos por un incendio coetáneo hacia el 2150 a. de C., momento en que posiblemente se abandone el asentamiento de Los Millares.

Los fortines ejercieron un fuerte control sobre las poblaciones del entorno de la Sierra de Gádor, presentes en pequeños poblados de piedemonte que, desde el IV Milenio a. de C., manifestaron su identidad a partir del enterramiento de sus muertos en necrópolis megalíticas que descendian hasta el valle del Andarax. Estas comunidades, como las del bajo Andarax, las del pasillo de Tabernas, la comarca de Gata-Nijar o el río NacimientoPasillo de Fiñana, quedaron integradas a lo largo del III milenio a. de C. en la unidad territorial controlada por Los Millares y adquirieron nuevos simbolos de identidad/pertenencia visibles en los sepulcros de falsa cúpula y en los ajuares funerarios contenidos en las necrópolis de Loma de Galera (Alhama), El Chuche (Pechina), Los Rubialillos (Tabernas), El Barranquete (Nijar) o Los Milanes (Abla).

Para comprender el control territorial del entorno inmediato de Los Millares debemos tener en cuenta también todo el poblamiento del área. Las tumbas enfatizaban el control de los valles, colocándose especialmente en los puntos en los que los cursos secundarios se incorporan a un río de mayor nivel. Este sistema permite marcar tanto las áreas susceptibles de ser explotadas, aun exiguas, como las rutas de desplazamiento a través de ellas, por las zonas llanas relativamente alejadas de los cursos fluviales. El sistema permite maximizar el uso de las construcciones e implica en primer lugar la anterioridad del control sacro (a partir de los megalitos) sobre el militar (fortines). En segundo lugar se aprecia la oposición entre el control más inmediato del territorio de Los Millares (con fortines) del más alejado (con tumbas). Finalmente se observa la similitud en las estrategias de ocupación del espacio, hasta el punto de que las concentraciones de tumbas resultan relativamente aisladas unas de otras (frente a lo que podemos ver en el Pasillo de Tabernas), con las necrópolis más amplias en los altiplanos explotables, donde diversas áreas cercadas inscritas en las necrópolis (CARA; RODRÍGUEZ, 1984) podrian hacer sospechar que se integrarian en el mismo lugar las tumbas, los rebaños y, tal vez, las viviendas.

Las prospecciones sistemáticas en el pasillo de Tabernas ofrecen sin duda los mejores datos para estudiar los límites de la influencia de Los Millares en los territorios algo más distantes de la cuenca del Andarax (CÁMARA; MOLINA, 2004). El sistema creado por la distribución de tumbas resulta mucho más com-

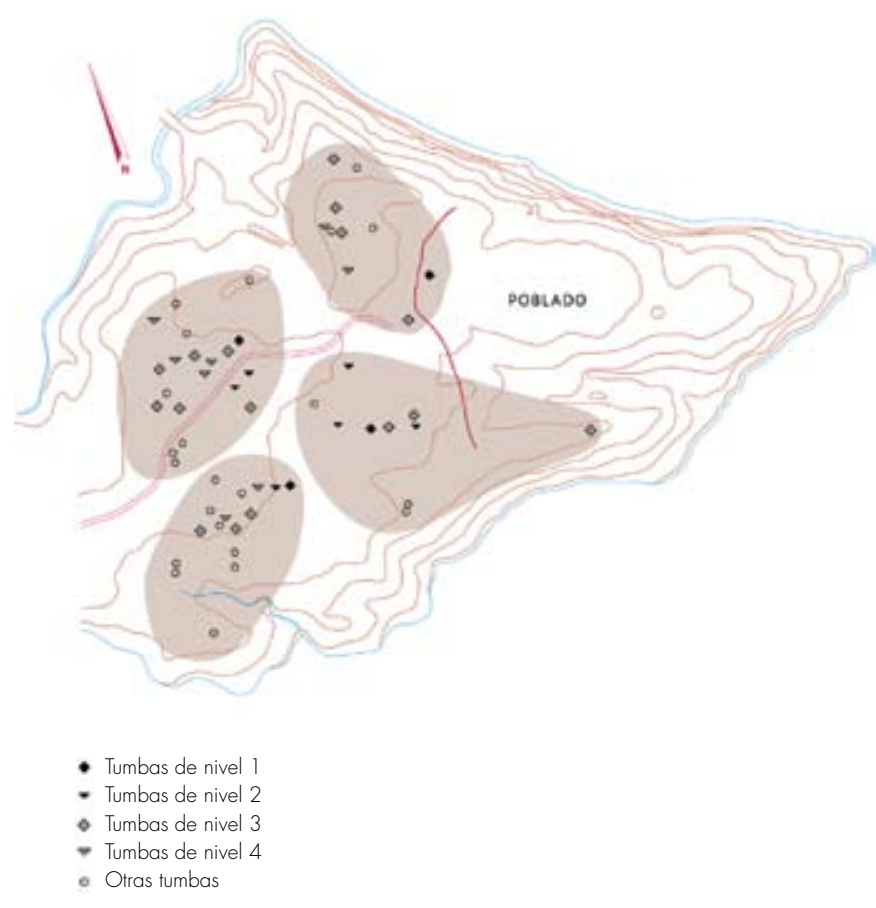

Necrópolis de Los Millares. Modelo de la agrupación y jerarquía de las tumbas. Mapa: Dpto. de Prehistoria, Universidad de Granada

plejo que el descrito para el bajo Andarax y supone, con su mejora por la continua adición de tumbas, la demarcación total de las rutas de desplazamiento no sólo desde el valle principal de Los Molinos hasta la sierra de los Filabres sino dentro de cada una de las cadenas montañosas perpendiculares a estos dos ejes (sierra de Velefique, hoya de la Matanza, Sierra Bermeja, etc.). Un importante elemento que nos puede indicar cómo en estas necrópolis dispersas la exhibición de la desigualdad quedaba unida a la demarcación de las rutas, es el hecho de que en cada agrupación de tumbas las que muestran mayor intervisibilidad están construidas siguiendo patrones formales diferentes (rectangulares donde dominan las tumbas poligonales o poligonales donde dominan las rectangulares) y, a menudo, son las únicas que muestran corredor.

La disposición de las tumbas y su intervisibilidad en cualquier caso implica la oposición entre dos unidades territoriales, una al este y otra al oeste, hasta el punto de que los poblados quedan situados detrás de la línea divisoria entre ambos conjuntos. Al oeste todos los asentamientos presentan dimensiones similares excepto Terrera Ventura, que podemos considerar como el principal asentamiento del Pasillo de Tabernas y es el único poblado de esta zona ligado a una necrópolis de tholoi, Los Rubialillos, con grandes cámaras circulares (GUSI, 1986). En el área oriental del Pasillo la concentración del poblamiento entre el Neolítico Reciente y el Calcolítico condujo al aumento de dimensiones de algunos poblados, la desaparición de otros y la preponderancia de El Marchalillo en la zona fronteriza y de Los Peñones en los accesos a Sierra Alhamilla. 


\section{Balnearios de Alhama de Almería y Sierra Alhamilla}

En torno a los balnearios, desde la Antigüedad, siempre se ha configurado una especifica cultura del agua siendo espacios de culto, curación y recreo por sus especiales propiedades curativas. Además, las fuentes termales son continuamente reutilizadas presentando, en la actualidad, valores patrimoniales de carácter histórico-arqueológico, etnológicos, sociales y paisajísticos.

Los paisajes termales almerienses, creados a lo largo de las diferentes generaciones que ocuparon este territorio, están formados, fundamentalmente, por balnearios y jardines, fuentes y lavaderos, balsas y huertas, de gran interés histórico $y$, además, presentan un importante valor medioambiental como islas refugio en medio de la aridez del entorno. En ellos se reflejan también los valores dominantes de cada época en su concepción ideológica de la salud y del ocio.

En la comarca del Andarax y valle de Tabernas existen numerosos manantiales de aguas calientes (Alboloduy, Alicún, Bentarique, etc.) y cuatro importantes balnearios: los baños de Lucainena de las Torres, los de Alfaro (Rioja), el balneario de S. Nicolás (Alhama de Almería) y el balneario de Sierra Alhamilla (Pechina). En todos los manantiales de aguas calientes existe una balsa de acumulación utilizada para enfriar las aguas antes de destinarlas al riego de una zona de cultivo próxima y que los vecinos han utilizado para bañarse durante el verano.

Los baños de la Marrana de Lucainena de las Torres fueron descubiertos hacia 1830 y esto dio lugar a la construcción de varios cortijos en su entorno. Primero se construyeron dos balsas, una para hombres y otra para mujeres, y en 1846 se amplió con un local de baños con cuatro habitaciones y sus correspondientes balsas, asi como habitaciones de alquiler con dormitorio, cocina y corral. El manantial era de poco caudal y se abandonó pronto. En la actualidad, el conjunto se encuentra muy transformado.

Los baños de Alfaro situados al pie del cerro Alfaro, eran muy frecuentados, en la segunda mitad del siglo XIX, por vecinos de la capital aquejados, sobre todo, por enfermedades de la piel. Abandonados desde principios del siglo $X X$, hoy se encuentran en estado ruinoso.

Los baños de Alhama de Almería aprovechaban el agua de la fuente principal o vieja y se componian de una balsa de riego y abluciones y de un lavadero asociado. Un terremoto en 1522 secó su manantial y hasta 1781 no volvieron a ponerse en funcionamiento cuando la hermandad de las Ánimas los construyó con el fin de sacar algunas limosnas de los visitantes y usuarios, vendiéndolos pocos años después por su escasa rentabilidad.

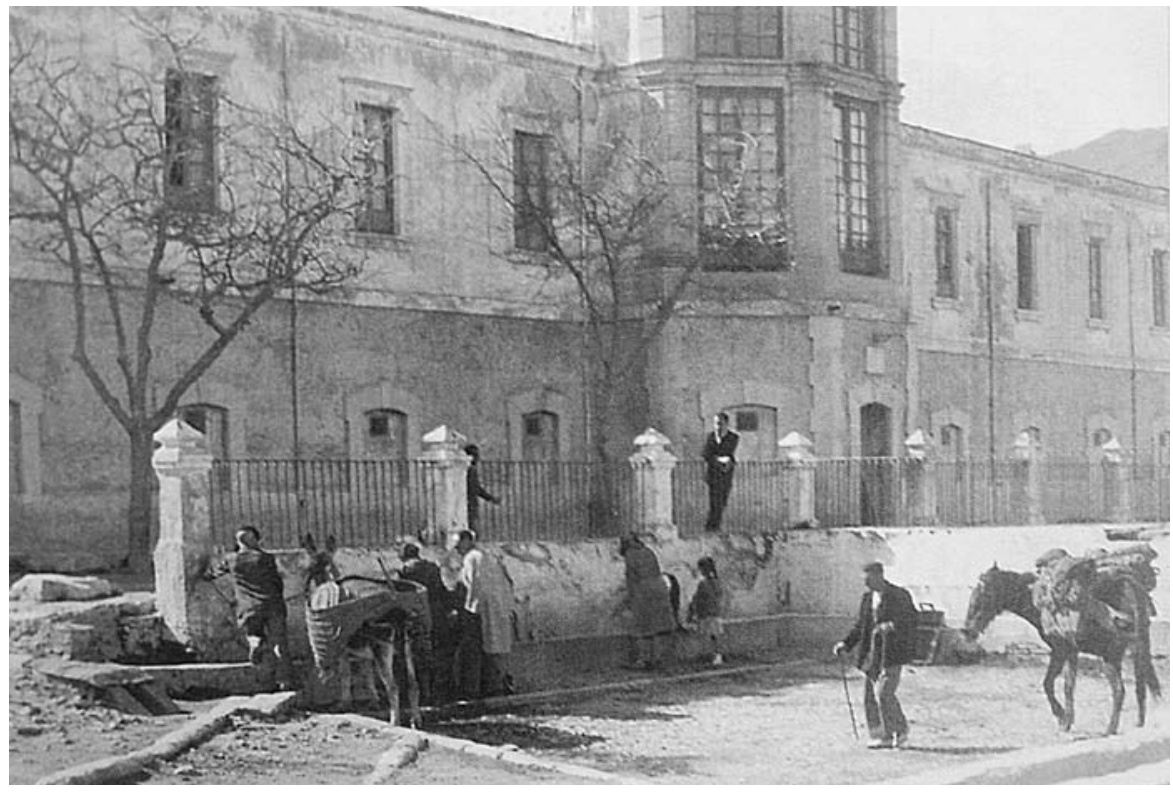

Fuente del balneario de San Nicolás (Alhama de Almería) a principios del siglo XX.

Fotógrafo desconocido, colección particular familia Barquero Artés. Fuente: AMATE (2007: 369)

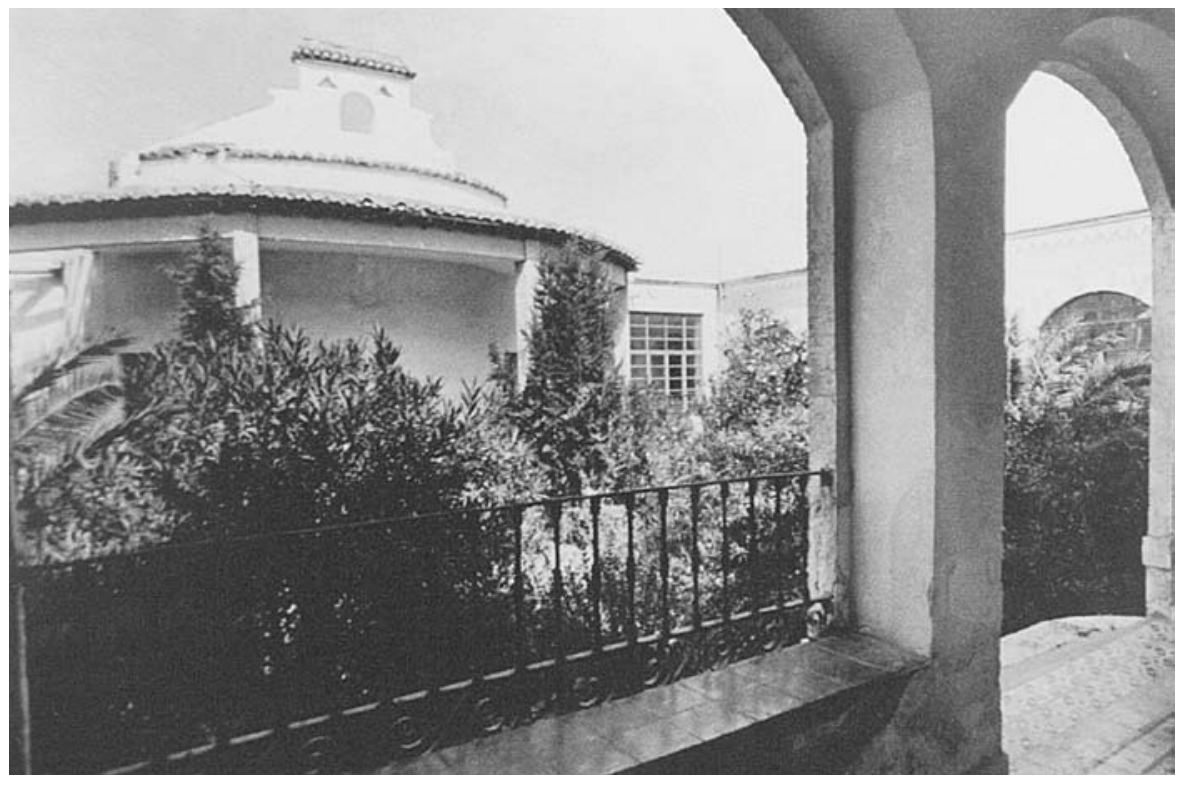

Balneario de San Nicolás (Alhama de Almería) a principios del siglo XX. Fotógrafo desconocido, colección particular Balneario San Nicolás. Fuente: AMATE (2007: 369)

En 1874, la pujante burguesía local con negocios en la exportación de la uva de mesa y en la minería, constituyó la Sociedad de Baños de San Nicolás, con 160 accionistas que se repartian las 400 acciones de la misma, con el fin de construir y explotar un moderno balneario, que debía de ser útil y práctico. Abierto desde 1877, la temporada seria desde el 15 de abril al 30 de junio y del 1 de septiembre al 31 de octubre y hasta la mejora de los medios de transporte la media anual de pacientes residentes rondaba el medio millar.
La construcción y ampliación del edificio duró varios años, prolongándose hasta 1881, y dotó al inmueble de elegantes departamentos de baños, con pilas de mármol de una sola pieza, gabinetes de duchas de todas formas y presiones, baños de vapor y una balsa independiente para los pobres de solemnidad, y además se preparó un salón de reuniones con piano y espejos donde se celebraban diferentes actos sociales como bailes, audiciones musicales y conferencias.

Los baños de Sierra Alhamilla son mencionados en las fuentes árabes por sus propiedades medicinales. El es- 


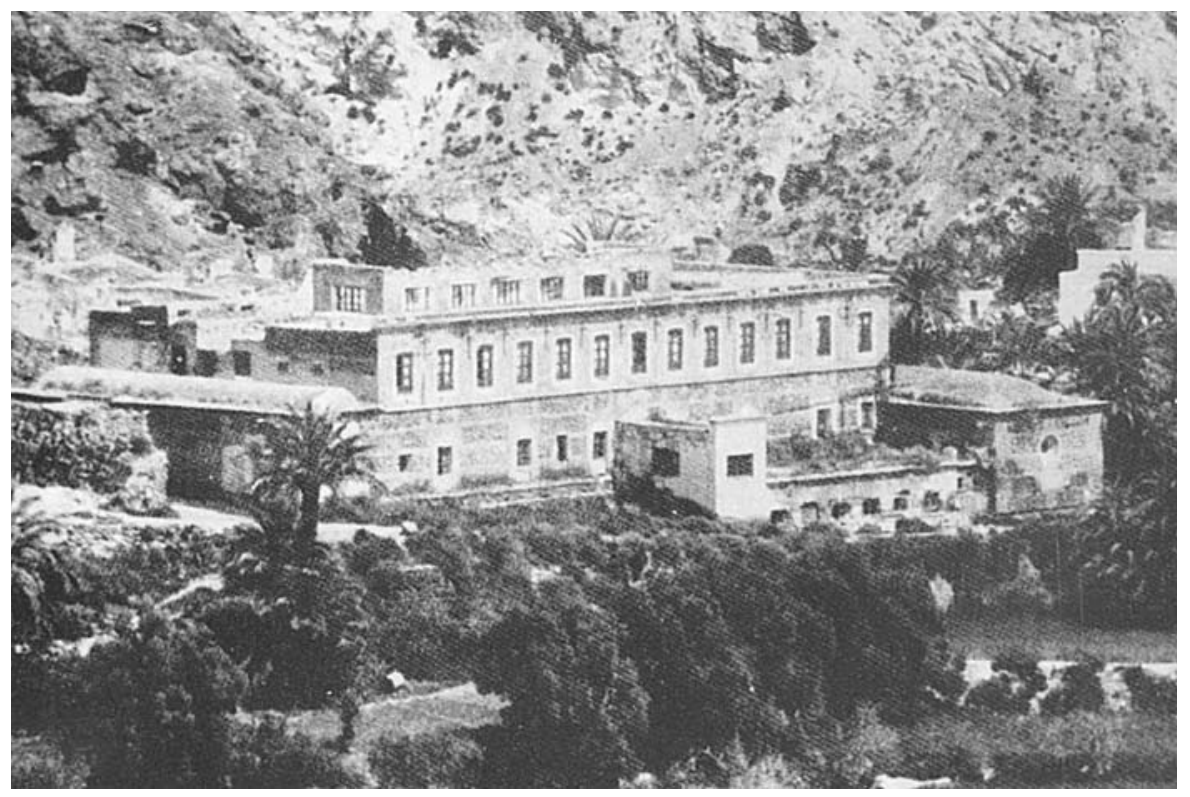

Balneario de Sierra Alhamilla (Pechina). Foło: Daniel Aubry. Fuente: TAPIA, 1980

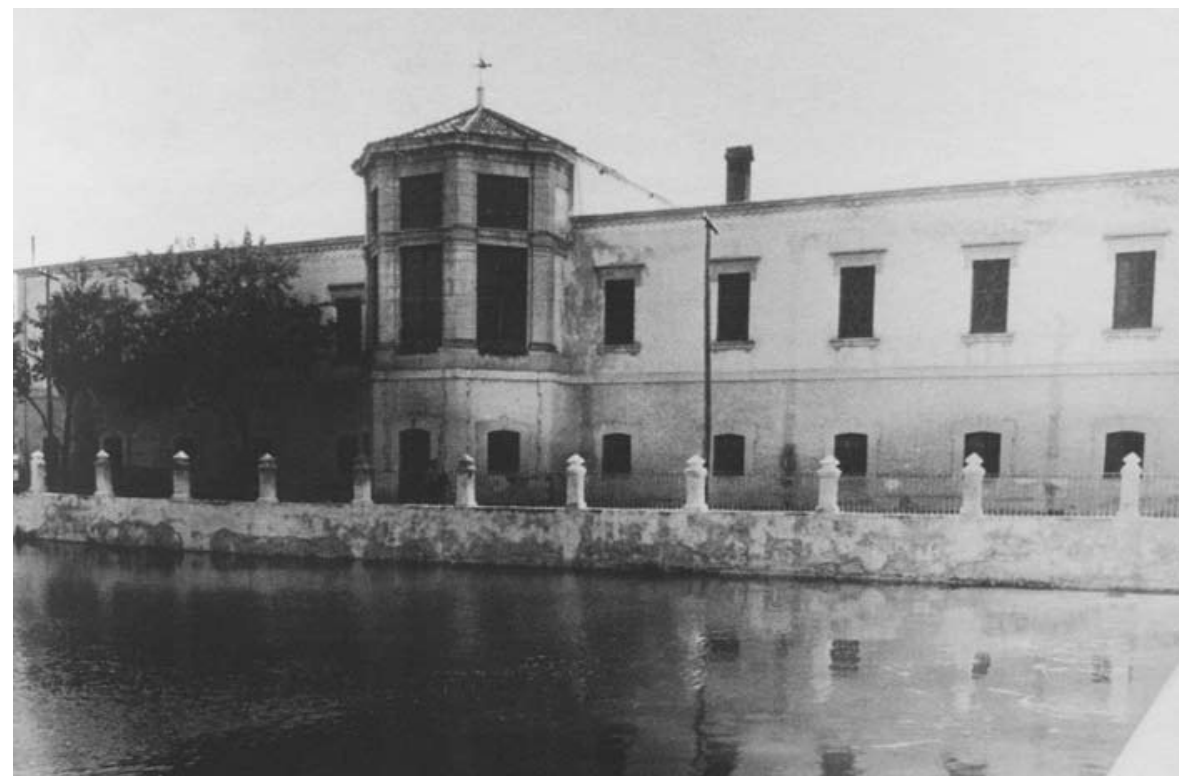

Balsa del Balneario de San Nicolás (Alhama de Almería) a principios del siglo XX.

Fotógrafo desconocido, colección particular Balneario San Nicolás. Fuente: AMATE (2007: 369)

tado actual del balneario se remonta a la Obra Pía de los Baños que el obispo Claudio Sanz y Torres mandó realizar, en 1777, para construir un edificio junto al manantial de aguas termales cuyas aguas y terrenos próximos había comprado, con el fin de atender a los pobres y a los enfermos del Hospital Real de Almería. Dispuso en torno a un patio rectangular, una serie de habitaciones para el baño de hombres y para mujeres, una capilla y una hospedería, habitaciones del bañero y el capellán, además de mejorar el camino desde Pechina. Posteriormente, fue desamortizado al decretar Carlos IV la supresión de las obras pias y, a mediados del siglo XIX, el Obispado de Almería, el Ayuntamiento de Pechina y la Diputación Provincial establecieron un pleito por su propiedad. Subastados en 1876, en los años siguientes pasaron por diferentes manos.

Este oasis de palmeras enclavado entre la aridez circundante y la actividad minera, gracias a los 16 kilómetros de ferrocarril minero activo desde finales del siglo XIX hasta 1927, se convirtió en un lugar de recreo y salud de la burguesia de la capital. En 1945 se establece una planta embotelladora de agua mineral y un año después el balneario fue cerrado por amenaza de ruina, hasta el

\section{Los paisajes termales} almerienses presentan importantes valores medioambientales y reflejan los valores dominantes de cada época en su concepción ideológica de la salud y del ocio año 1991 cuando se reabrió tras su reforma completa, gracias al impulso personal de D. Isidro Pérez.

En los alrededores encontramos numerosos bienes del patrimonio minero herencia de las diferentes empresas americanas e inglesas que desde mediados del siglo XIX explotaron el hierro de esta sierra: pozos, hornos de calcinación, escombreras, planos inclinados y la antigua estación ferroviaria El Chorrillo.

Juan Salvador López Galán, Departamento de Protección, Delegación Provincial de Cultura de Almeria 


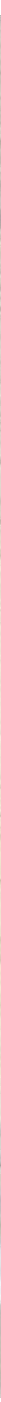

Poblado del Oeste Western-Leone, en el desierto de Tabernas. Foto: Juan Carlos Callaza, IAPH 


\section{El desierto, la luz y el cine}

Ignacio M. Fernández Mañas, historiador del cine
"Escritura del viento en el desierto"

Octavio Paz

Hace casi sesenta años la idiosincrasia del paisaje de las ramblas de Gérgal y de Tabernas, en la cuenca del río Andarax, cautivó la mirada de los cineastas. Desde entonces, se han venido creando innumerables historias hechas de miradas, sombras y luces en este territorio imponente. La quietud insondable de este abrupto, severo y majestuoso paisaje se armonizó con el ajetreado, turbulento y desconcertante mundo del cine. Sus tres mil horas de insolación anual facilitaban el trabajo de esta industria tan dependiente de la luz. Los amaneceres largos y los atardeceres lentos simplificaban la labor creativa de los directores de fotografía y permitían que los rodajes diariamente se prolongaran más de lo habitual.

Aunque 1951 marca el inicio de la historia de los rodajes en Almería con la película española La llamada de África, de César Fernández Ardavín, no fue hasta el rodaje de Oeil pour oeil en 1956 cuando el desierto de Tabernas se convirtió en escenario cardinal de una producción cinematográfica. El gran decorador español Gil Parrondo asumió las labores de localización: "... quedé totalmente alucinado con el paisaje de Tabernas. Nunca había visto nada tan hermoso. Me parecia imposible que esos parajes se encontrasen en España. Las localizaciones las realicé junto con el director, Cayatte, Rafael Carrillo, que era el director de producción, y otra tercera persona que no recuerdo bien quién era, quizá fuese el operador, Chistian Matras. Luego no pude hacerla porque tenía otro contrato ya firmado en Madrid. Se encargó de la decoración un buen amigo mio, José Algueró" (FERNÁNDEZ MAÑAS, 1997: 35).

Sobre la elección de los paisajes de Almeria, el propio director de la película declaró al fotógrafo almeriense Carlos Pérez Siquier en la revista Afal: "...necesitaba un paisaje desértico, dramático. Había visitado Libano, Siria, Jordania, Egipto... Todo es igual, demasiado monótono... Por fin, en la Oficina Geográfica de Paris, me indicaron la posibilidad de encontrar en el sudeste español -zona casi desconocida incluso para los propios españoles- lo que iba buscando. Vine aqui y quedé profundamente impresionado. Esto es único en el mundo, de una belleza realmente sobrecogedora" (PÉREZ SIQUIER, 1956).

El diseño de producción corrió a cargo de Jacques Colombier y, tal como refería Parrondo, la realización de los decorados recayó en José Algueró, quien iniciaba su amplia relación con este estudio abierto que ha sido y es Almería. En los parajes de Tabernas se montó un poblado árabe y se construyó un funicular en un desfiladero cercano al municipio de Rioja.

Sería a lo largo de la década de los sesenta cuando el balneario de Sierra Alhamilla, el barranco del Infierno, la zona minera de El Chorrillo, el monte Alfaro, las balsicas de Alfaro, Las Salinillas, La Sartenilla, los llanos del Duque, el valle del Búho, la venta Araoz, la venta Cañicas; o las ramblas Benavides, del Cautivo, de Indalecio, Lanújar, Viciana, entre otros parajes, se convertirian en lugares preferentes para todo tipo de producciones cinematográficas, haciendo que Almeria significase dentro de la historia del cine moderno "un género en sí mismo... en cuanto establece una íntima conexión, estética y no anecdótica, entre las películas alli rodadas, independientemente de su idiosincrasia" (AGUILAR, 2001: 331). Estos lugares fueron los emblemas del llamado "Hollywood europeo", como fue denominada Almería en estos años. El género western, fundamentalmente, marcó los jalones de este fulgor cinematográfico en una provincia que, por entonces, era la que menos renta per cápita tenía de España; una provincia deprimida, olvidada, carne de emigración y carente de infraestructuras básicas.

Tierra brutal, coproducción hispano-americana, dirigida por Michael Carreras, abrió en 1961 el largo camino que llevaria a que se rodasen más de doscientos westerns en estos parajes. No en vano, el director español Joaquín Romero Marchent contaba: "Los paisajes que viera en el copión de Tierra brutal en la sala de montaje se adecuaban perfectamente a los que necesitaba para mi próximo film. El sabor de la venganza... Para que las películas se parecieran de verdad a lo que eran los westerns americanos..." (SOLER, 1993). Por ello, rodaría varias veces en estos espacios du- 


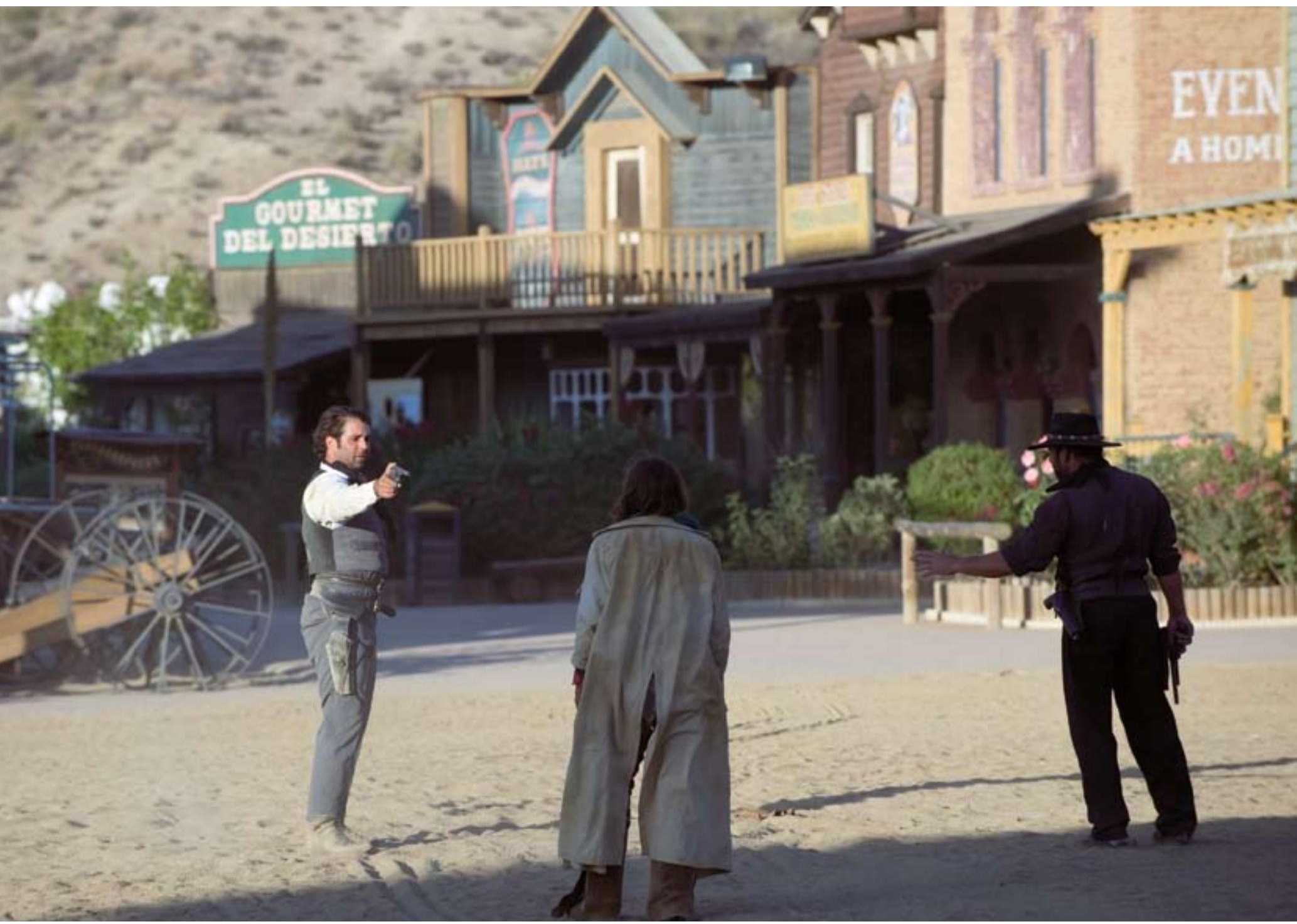

Espectáculo del Oeste en el parque temático Oasys, en el desierto de Tabernas. Foto: Juan Carlos Callaza, IAPH

rante el primer lustro de los sesenta con títulos como Antes llega la muerte -1964- o La muerte cumple condena-1965-.

Sin embargo fue tras el éxito de la película de Sergio Leone Por un puñado de dólares -1964-, cuando la fiebre del western se desató. El Ilamado spaguetti-western hizo que en estas ramblas, en estas áridas, secas, duras y alejadas localizaciones se oyesen voces en castellano, italiano, alemán o inglés. La muerte tenía un precio-1965-, el segundo western de Leone, comenzaba con una vista general de los llanos del Duque sobre los que se sobreimpresionaban los títulos de crédito y se escuchaba la música de Ennio Morricone. Para este film, el director artístico Carlo Simi diseñó el poblado de Fraile', que se levantó en el paraje denominado Cortijo Genaro, dentro del municipio de Tabernas. Su constructor fue Miguel Montoro y los decoradores Carlo Leva y Rafael Ferri. La superficie ocupaba aproximadamente unos cuarenta mil metros cuadrados. Lógicamente, una parte importante de la película transcurría en este poblado, que recreaba la ciudad de El Paso, y en el que se edificaron la oficina del sheriff, la cárcel, el salónhotel y el banco. Otras localizaciones para esta película mítica del western mediterráneo, dentro de la cuenca del Andarax, fueron las balsicas de Alfaro y las ramblas de Indalecio y Viciana, que se aprovecharon para las galopadas de la banda de Indio (personaje interpretado por Gian María Volonté). En 1966, Leone culminó su trilogía del dólar con El bueno, el feo y el malo. De nuevo se utilizó "El poblado de Fraile" para caracterizar tres ciudades distintas; y además la Sartenilla para instalar el poblado fantasma del prólogo, en el que Tuco (Eli Wallach) mata a tres pistoleros; los Llanos del Duque para plasmar el lugar en el que el Rubio (Clint Eastwood) abandona a Tuco desmontado y con las manos atadas; la rambla Lanújar, por donde marchan Tuco y el Rubio, intentando el primero evitar descubrirle el lugar exacto del cementerio de guerra; o el acceso al Colativí, al que ya había recurrido Leone en su anterior western.

Con el aumento de producciones de este género, en otras zonas de la cuenca de las ramblas de Gérgal y Tabernas del Río Andarax se construyeron otros poblados, algunos de ellos todavía en pie (poblado de Juan Garcia ${ }^{2}$ o el rancho Leone ${ }^{3}$ ) y otros, lamentablemente, en ruinas o desaparecidos (la fortaleza construida para la película $E$ I Cóndor-John Guillermin, 1970-; el poblado de Tecisa; el rancho de las Salinillas; el poblado Mimbrero; el fuerte Gobi; etc.). 


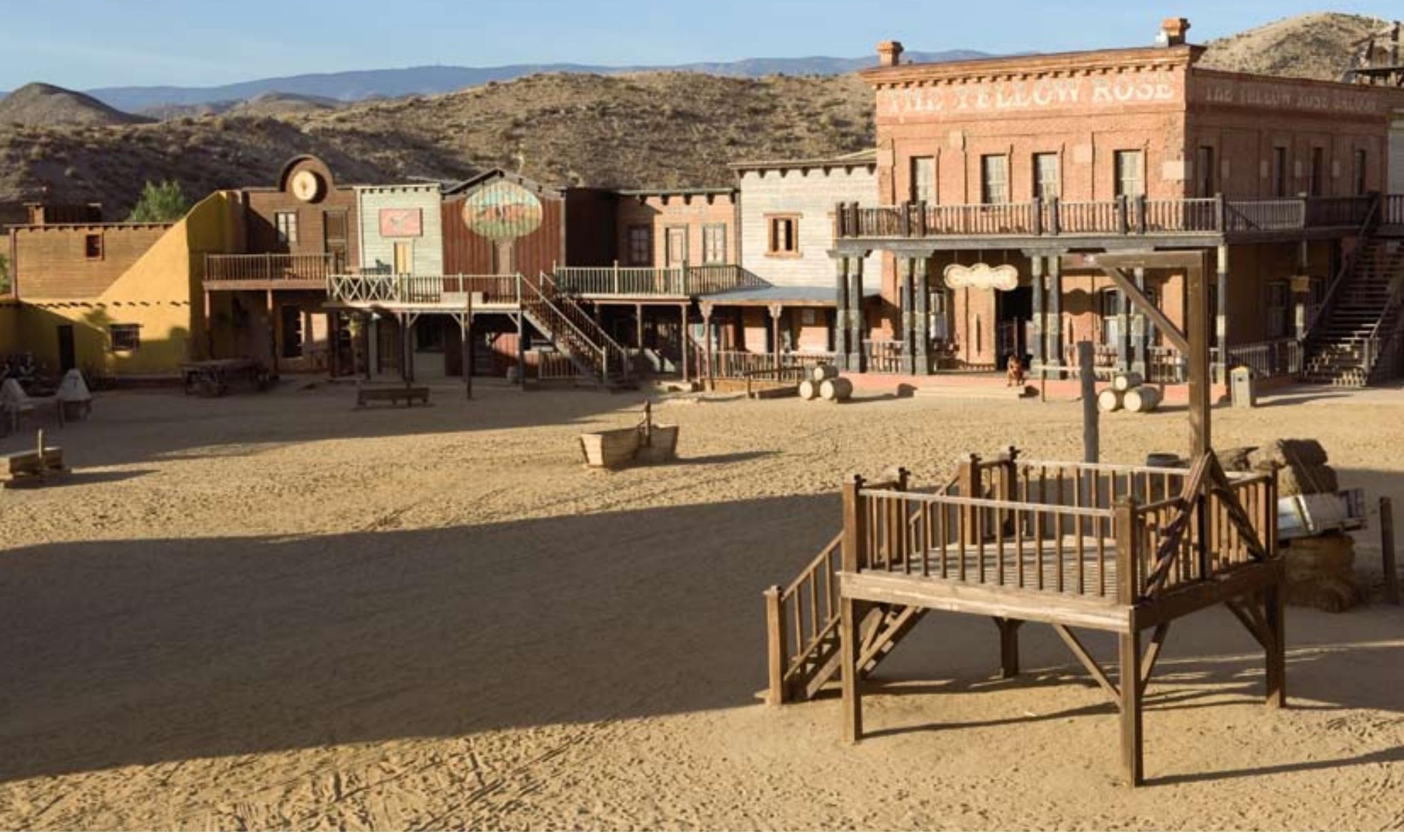

Poblado del Oeste Minihollywood en el parque temático Oasys. Foto: Juan Carlos Callaza, IAPH

Este auge de coproducciones inspiradas en el mundo del western americano entre 1965 y 1975 provocó que estas tierras fueron tomadas por las huestes cinematográficas, creando la ilusión de estar en los predios de Arizona, de Texas, de California o en la zona fronteriza mexicana, por las que cabalgaban y disparaban interpretando historias de robos de trenes, revolución mexicana o cazadores de recompensas intérpretes como los anteriormente mencionados o Brigitte Bardot, Ernest Borgnine, Charles Bronson, Yul Brynner, Claudia Cardinale, James Coburn, Sean Connery, Alain Delon, Henry Fonda, Giuliano Gemma, Terence Hill, Burt Lancaster, Lee Marvin, Francisco Rabal, Burt Reynolds, Bud Spencer, Fernando Rey, Lee Van Cleef, Raquel Welch, Orson Welles y tantos otros. De este modo, estos paisajes consagraron a Almería como la localización "del cinema western piü importante dopo le principali location del West americano" (GABERSCEK, 2005: 2).

Pero no sólo de western se alimentaron estas tierras durante este periodo de apogeo de la industria cinematográfica, otros géneros también contaron con sus escarpados y alucinantes paisajes para crear otro tipo de historias fílmicas. Para Lawrence de Arabia
-1962- de David Lean, con Omar Sharif, Peter O'Toole y Anthony Quinn, hito en el género histórico y bélico, el escenógrafo John Box creó ex profeso un oasis en la rambla Viciana para algunas de sus escenas y luego serviria como escenario para otras muchas películas. En Cleopatra -1963- de Joseph L. Manckiewicz, el diseñador de producción John DeCuir recreó la batalla de Farsalia, con la que comenzaba la película al finalizar los títulos de crédito, en la rambla del Cautivo, contando con la interpretación de Rex Harrison en el papel de Julio César. Años después, en 1966, John Lennon bajo la dirección de Richard Lester trabajó para la antibelicista Cómo gané la guerra en la misma rambla. Para Mercenarios sin gloria, André de Toth dirigió en 1968 a Michael Caine en las ramblas de Tabernas y Rioja. Gil Parrondo consiguió el Oscar en 1971 a la mejor dirección artística por su trabajo en la película bélica Patton -1969- de Franklin J. Schaffner, recreando en el valle del Búho la batalla de El Guettar, u otros momentos de las hazañas de este general en la Segunda Guerra Mundial en otros lugares de la provincia, como en la carretera de Canjáyar, en los términos de Enix y Felix, etc. La cuenca del Andarax sirvió para escenificar en este tipo de películas acciones en el norte de África o en distintas partes de Arabia. 


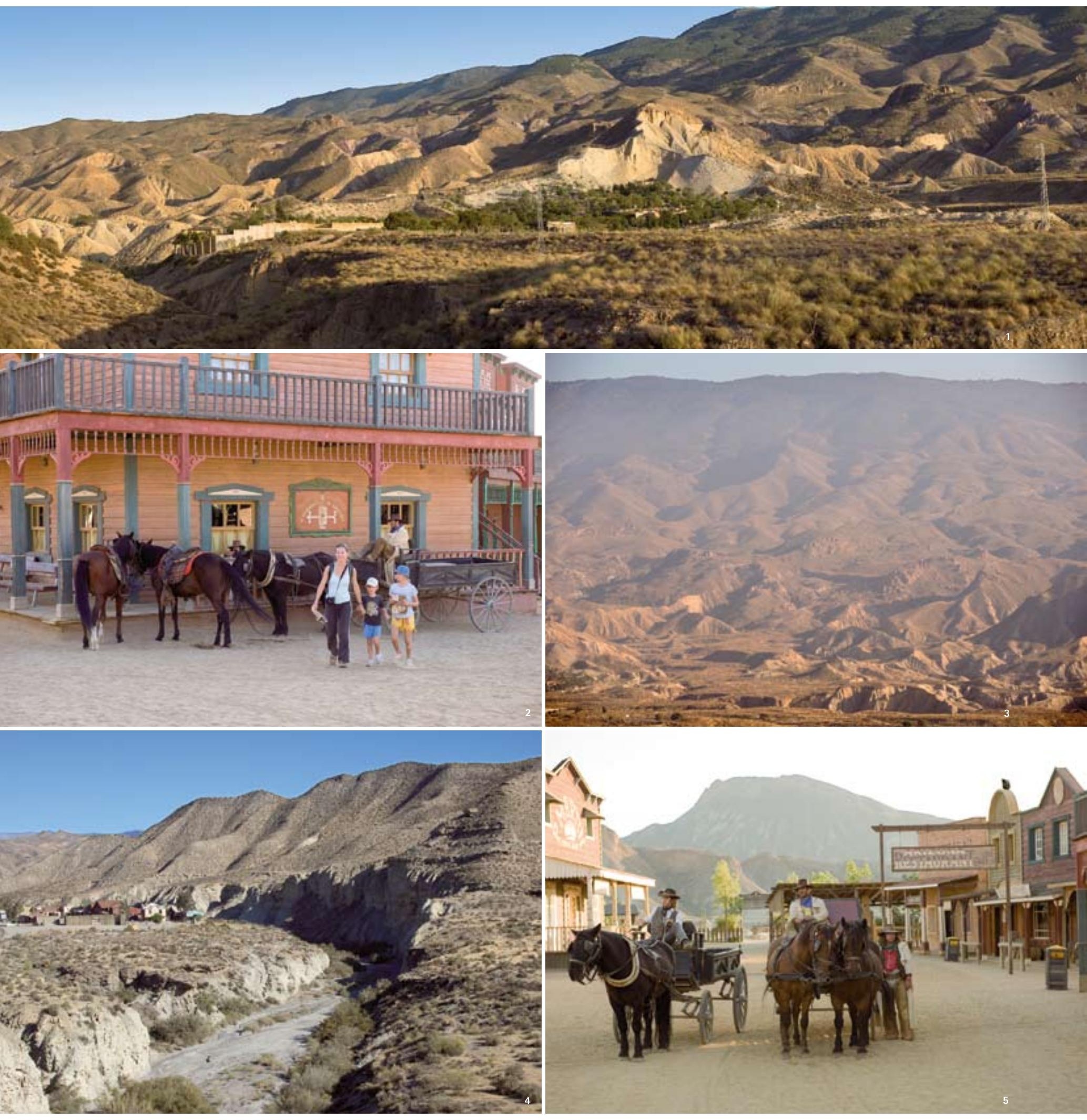

1.Vista del desierto de Tabernas, donde está situado el parque temático Oasys con el poblado del Oeste Minihollywood.

2. Turistas en Minihollywood.

3. Desierto de Tabernas.

4. Poblado del Oeste Western-Leone.

5. Espectáculo del Oeste en Minihollywood.

Fotos: Juan Carlos Callaza, IAPH 
Pero en 1975 se constata que la crisis se ha adueñado del Hollywood europeo. Los factores económicos, políticos y estéticos que se aunaron para levantar esta etapa de grandeza cinematográfica desaparecieron: la cancelación de las medidas legales de apoyo a las coproducciones, el agotamiento del western europeo, la reducción de las películas bélicas sobre la Segunda Guerra Mundial, la crisis del petróleo... Del mismo modo que se fue deshaciendo todo este entramado, los decorados levantados se desmoronaron, arrastrados por el viento, quemados por el sol y olvidados por el cine. El viento y el león -1975- de John Milius acaso marque por sus características el final de la época dorada del cine en Almería. De nuevo Gil Parrondo, como director artístico, transforma la Almería de 1974 y nos ofrece un seductor trabajo de decoración recreando Tánger en el año 1904, así como los desérticos parajes de Gérgal en donde el jeque árabe Mulay Hamid El Raisuli (Sean Connery) tenía sus campamentos. En 1976, todavía la producción británica Valentino -1977-, particular visión biográfica de Rodolfo Valentino dirigida por Ken Rusell, propició el hecho de que en "El poblado de Fraile" se rememorase visualmente el rodaje de un western en los estudios de Hollywood, gracias al trabajo del director de arte Philip Harrison.

De todos modos, no quedó ninguna infraestructura, ningún estudio que pudiera frenar esta decadencia y pudiera resolver el trabajo de especialistas, de caballistas, de localizadores, de transportistas, de carpinteros, de albañiles, que habian encontrado en esta industria una forma de vivir en una de las provincias más deprimidas de España. Fracasaron las medidas de apoyo de los planes de desarrollo de la etapa tecnócrata del franquismo. Sólo los parajes permanecian. Y otras historias y otras formas audiovisuales encontraron acomodo en ellos. No fue con la intensidad de antes, pues no se puede olvidar que el western supuso el setenta por ciento de las producciones en la década dorada. Las producciones para la televisión fueron un componente crucial a partir de los ochenta: capítulos de series de televisión, anuncios publicitarios y los videoclips.

De los dos formatos primeros ya en las dos décadas anteriores se habian grabado episodios para series y anuncios: capítulos para la serie norteamericana The Rat Patrol-1966-, películas para la televisión alemana como Maximiliano Von México -1969-, varios capítulos de la serie española Curro Jiménez -1975 y 1977- o anuncios de cerveza y de alimentación. En las dos últimas décadas del siglo XX, la cuenca del Andarax volvió a ser escenario para capitulos de series bélicas sobre la guerra de Irak (Domsday Gun -1993-), de aventuras (El joven Indiana Jones -1991- o Aventura Eureka-1992-), policiacas (Poirot-1993-), del Oeste (La reina de espadas -2000-) o anuncios de automóviles, de todo tipo de bebidas, de grupos petroquímicos, de golosinas, de tabaco, de cosméticos, inspirados en los westerns rodados en las ramblas y los poblados de antaño y dirigidos la mayoría de las veces a televisiones extranjeras. Y además, un nuevo producto, el videoclip de grupos musicales, halló en estas tierras ya de cine el referente idóneo para ambientar las letras de las canciones o el estilo de los cantantes o grupos: Joaquín Sabina, Sting, Europe, Queen, La Frontera, Siniestro Total, David Bisbal, Tam Tam Go, The Pogues...

Sin embargo, no por ello se dejó de rodar para la pantalla grande. Espectaculares superproducciones se sirvieron de estos paisajes compactos, firmes, perturbadores, indefinibles. Indiana Jones y la útlima cruzada fue la que más impacto tuvo. En 1988 Steven Spielberg con Harrison Ford y Sean Connery filmó secuencias en las ramblas Indalecio y Trujillo. También el cine español se fijó en estos paisajes. Ya lo hizo en los sesenta con westerns en la línea estilística de los italianos, pero ahora en los últimos años del siglo XX y en los primeros del XXI, Mario Camus con José Coronado y Ana Duato en La vuelta de El Coyote -1998- o Alex de la Iglesia con Sancho Gracia y Carmen Maura en 800 balas -2002- volvieron, desde perspectivas diferentes, a emplazar historias filmicas en los ámbitos de la cuenca del Andarax. E incluso la joven cineasta inglesa Linne Ramsay integró la vida cotidiana y tradicional de Ohanes en su película Morvern Callang -2002-. El mundo del cortometraje español, auspiciado por el Festival Internacional de Cortometraje Almeria en corto, desde 2003 ha encontrado también en estas zonas los rincones para aportar nuevas miradas.

El cine a esta cuenca del Andarax le ha dado resonancia mundial. El cine mostró las incalculables posibilidades para que la imaginación audiovisual pudiera crear fantasias e historias que nos conmuevan ante una pantalla. El cine descubrió que en este paisaje están todos los siglos, todos los tiempos, que en el silencio polvoriento de sus ramblas había emoción. El cine halló la forma de sacar prosperidad de su sequedad y dureza, hizo fecundo este desierto, le ofreció la posibilidad de que miles de almerienses pudieran encontrar en los trabajos de la industria cinematográfica un modo para sobrevivir en una época paupérrima para esta provincia como fue la del franquismo. El cine sigue siendo un modo viable de seguir generando trabajo e imaginación. Esta cuenca árida, abrasadora, todavía puede seguir poblándose por unas horas, por unos días o por unas semanas con la gente del cine, todavía su filón no se ha agotado y puede ofrecer nuevas e imaginativas historias, dejando una escritura, una huella intangible como la del viento en el desierto.

\footnotetext{
Notas

${ }^{1}$ Posteriormente se conocería como el poblado Minihollywood. Se denominó "El poblado de Fraile" debido a que Alfredo Fraile era el socio mayoritario de Arturo González y productor ejecutivo de la película por parte española.

${ }^{2}$ Conocido actualmente como el poblado Fort Bravo (antes Texas Hollywood).

${ }^{3}$ Proyectado por el director artístico italiano Carlo Simi para el rodaje de Hasta que Ilegó su hora (1968), de Sergio Leone.
} 


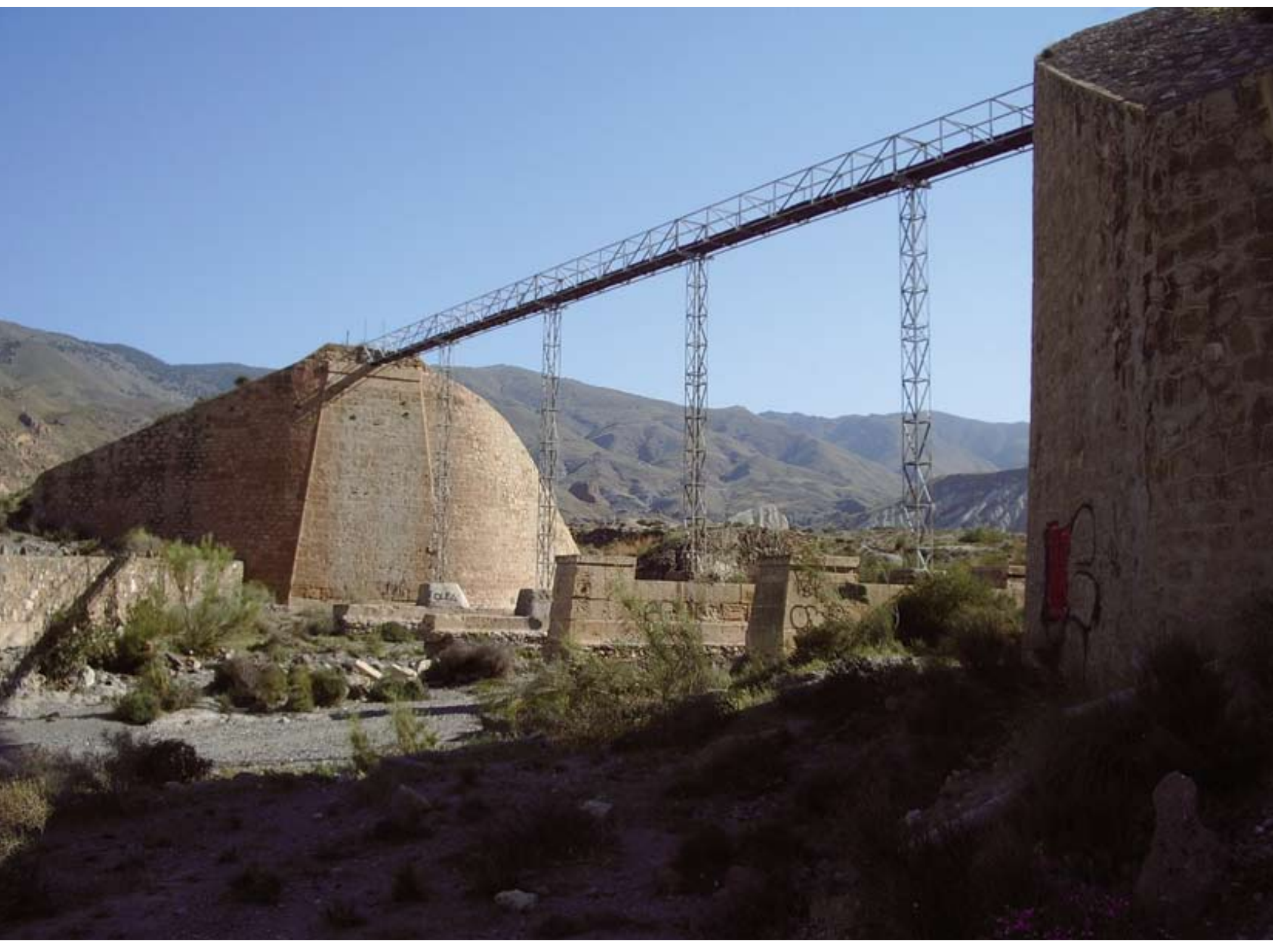

Puente de la rambla de Espinaza. Fuente: Fondo ASAFAL 


\section{Itinerario por el antiguo ferrocarril de Sierra Alhamilla a Almería: recuperación de un trazado para los ciudadanos}

Antonio Aguilera Cantón,

Asociación de Amigos del Ferrocarril de Almeria, ASAFAL

\section{ORIGEN DEL FERROCARRIL}

Concebido a finales del siglo XIX para transportar mineral de hierro desde varias explotaciones mineras de la parte occidental de Sierra Alhamilla hasta la playa de las Almadrabillas de Almería, fue el primer ferrocarril que llegó a la capital almeriense. Su existencia fue azarosa desde su misma gestación y tuvo una vida corta, sin embargo, nos ha quedado un legado patrimonial que deberíamos proteger del deterioro físico y del olvido.

Antes de "pisar" el terreno por donde circularon unas pequeñas locomotoras de vapor que arrastraban pesadamente los vagones cargados con mineral de hierro, debemos repasar brevemente la historia de este modesto ferrocarril minero, que se inicia con la puesta en marcha de la explotación de varios yacimientos de mineral de hierro en Sierra Alhamilla, impulsados por un empresario neoyorkino: William Dexter Marvell. Éste decide construir un ferrocarril que sacara la producción hasta el puerto de Almeria y aprovechar, al mismo tiempo, el trazado para comunicar los pueblos del bajo Andarax con los famosos baños medicinales de Sierra Alhamilla y la propia capital. En 1886 comienzan las obras y en 1888 está en servicio. Sin embargo, desde un principio el negocio fue ruinoso y las minas funcionaron irregularmente y no cumplieron con las expectativas depositadas en ellas; ni siquiera el transporte de viajeros aportaba lo suficiente para hacer rentable al ferrocarril. Ante esta situación, los acontecimientos se suceden y la propiedad de las minas y el propio ferrocarril se transfieren varias veces desde que The Marvell Iron Co Ltd. fuera la primera sociedad en el negocio en 1886, pasando por The Almeria and Alhamilla Railway Company Limited, The Gergal Railway and Mines Company Limited, The Alquife Mines and Railway Company Limited y The Chorrillo Almeria Railway Company Limited, respectivamente, hasta que, alrededor de 1919, las minas van agotándose o inundándose de agua al llegar al nivel freático. El 17 de noviembre de 1927 circuló el último tren y con ello propició el abandono y el expolio inmediato de todos los bienes.

Este ferrocarril minero tenía una longitud total entre El Chorrillo y el muelle de Almería de 15.859 m, con una pendiente me- dia de 22\%, siendo la sección más dura la parte alta junto a la sierra. Curiosamente se eligió un ancho de vía inusual: $914 \mathrm{~mm}$, equivalente a 3 pies ingleses, medida que en España solamente adoptaron los ferrocarriles de Mallorca y Sóller (Baleares) y el ferrocarril de Irún al Puente de Endarlaza (Guipúzcoa). A lo largo del recorrido existían cinco estaciones: Chorrillo, Alfaro-apeadero, Pechina, Huércal y Almería, de las que únicamente subsisten la primera y la tercera, aunque en un estado de ruina. A las estaciones de Chorrillo y Alfaro llegaban los cables aéreos con el mineral procedente de varias minas $y$, por tanto, eran los puntos de carga del ferrocarril.

El parque móvil que disponia la compañia para la explotación diaria era de tres pequeñas locomotoras de vapor alemanas tipo 030WT Jung que llevaban los nombres de Almeria, Pechina y Huércal, y que fueron desguazadas hacia 1946. El material remolcado lo componian unos 40 vagones para mineral de dos ejes con una carga media de $8 \mathrm{tm}$., además de otros vagones de varios tipos. También contaban con varios coches para viajeros de $2^{\text {a }}$ y $3^{\text {a }}$ clase de dos ejes y un coche break para los directivos; todos fueron desguazados. Habitualmente circulaba un tren diario cargado con mineral de hierro entre El Chorrillo y el muelle de Almería, descargándose en la playa de las Almadrabillas para su posterior embarque en barcazas hasta los buques fondeados en la rada. En cuanto a los trenes de viajeros, en los mejores tiempos del ferrocarril hubo cuatro o más trenes, hasta que la crisis redujo el servicio a dos semanales $y$, finalmente, uno sólo los domingos. Además de los trenes puros, también hubo trenes mixtos (viajeros y mercancias).

A pesar de que la mayoría de los elementos de este pequeño ferrocarril no existen, aunque muy deteriorados, aún podemos disfrutar todavía de algunos de sus restos, amenazados tanto por el paso del tiempo como por la especulación inmobiliaria y en medio de la desidia absoluta de las administraciones. $Y$ eso que una buena parte de la línea presenta cualidades excepcionales para su puesta en valor como vía verde, por lo favorable de su trazado, fácil acceso, su cercanía a núcleos poblados y la exótica belleza de algunos de los parajes que atraviesa. Un recorrido por 


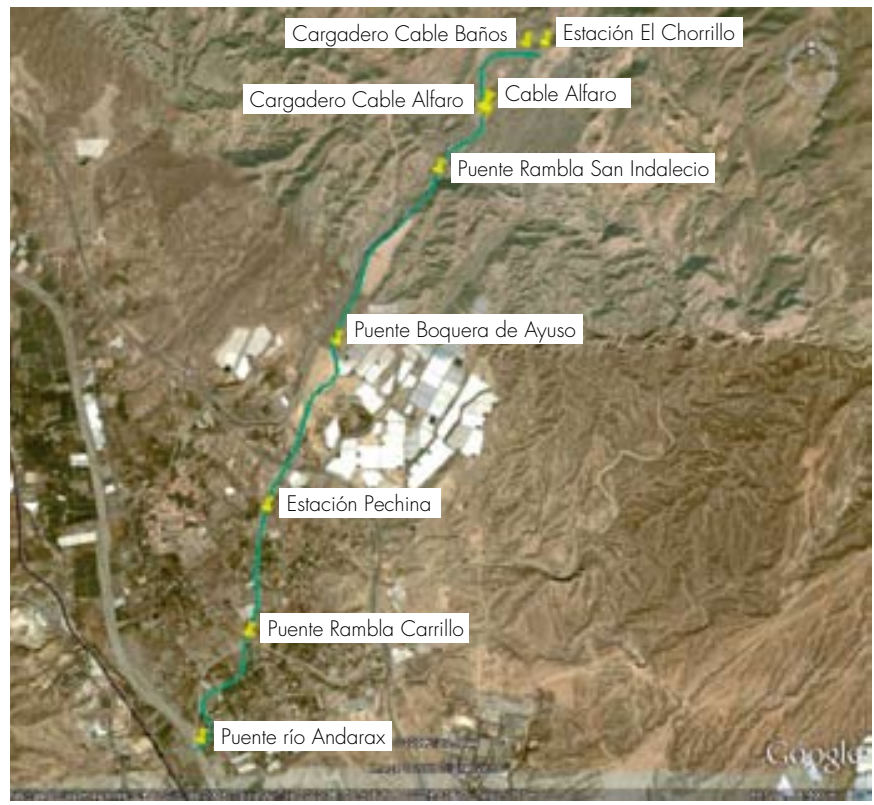

Itinerario por el antiguo ferrocarril de Sierra Alhamilla a Almería. Mapa: Mario López Martínez, a partir de Google Maps

sus vestigios nos pueden ayudar a comprender cuan importante es preservar nuestro patrimonio industrial para las presentes y futuras generaciones.

\section{RECORRIDO POR EL TRAZADO FERROVIARIO}

El trazado original ha desaparecido por completo desde la vieja estación de Pechina, aún en pie y perfectamente reconocible, hasta Almería. El desarrollo agrícola y urbano de los municipios por los que atravesaba el ferrocarril (Pechina, Huércal de Almeria y la propia capital) ha borrado cualquier vestigio reconocible de la traza o se ha reconvertido en una calzada asfaltada, como es el caso de la denominada carretera de Sierra Alhamilla en Almería. Sin embargo, milagrosamente, aún permanece casi intacta la parte alta o inicial de la línea que, sin lugar a dudas, es la más espectacular y objeto de nuestro interés.

El recorrido se inicia en la cabecera de la línea, en la falda de Sierra Alhamilla y en las proximidades de los baños termales del mismo nombre, en el paraje denominado El Chorrillo, a una altitud de $360 \mathrm{~m}$ aproximadamente. No es fácil reconocer lo que fue el kilómetro cero de la línea ferroviaria: estación, depósito de locomotoras, viviendas de ferroviarios y mineros, cantina, el cargadero de minerales y la propia traza de la vía. Todo está en estado de ruina y el lugar es escenario de batallas incruentas entre aficionados al paintball; a pesar de todo, son perfectamente reconocibles si nos apoyamos en un plano que reconstruye estas instalaciones (GÓMEZ MARTíNEZ; COVES NAVARRO, 2000: 114, vista aérea $\left.n^{\circ} 8\right)$.

Tras recorrer los distintos edificios que aún quedan en pie, no queda más que adentrarse en el trazado desde la propia esta- ción, sorteando previamente un pequeño pontón, que nos lleva hasta el cargadero del cable de El Chorrillo, del que tan solo queda el muro de mampostería paralelo a las vías y donde se aprecia la vía de culatón, que facilitaba las maniobras de los trenes cargados y vacios. En ese punto, tomamos la traza de la izquierda para salir poco a poco al Ilano por la explanación, perfectamente definida, hasta que se interrumpe bruscamente por culpa de los movimientos de tierras que hace algunos años se iniciaron con la intención, al parecer, de construir un invernadero agrícola o algo similar y que no llegó a culminarse. A pesar de ello, es fácil volver a la traza si tomamos como referencia las ruinas del segundo cargadero de mineral, el del cable Alfaro, para ir acercándonos por un terraplén cada vez más acusado que nos llevará hasta la primera gran obra de ingeniería de este ferrocarril minero: el espectacular puente de Espinaza, que salva la rambla del mismo nombre; con una longitud de $43 \mathrm{~m}$, conserva los estribos y cuatro pilastras de silleria de apoyo intermedio de la estructura metálica que formaba el puente, hoy desaparecida. En la actualidad, la explanación del ferrocarril ha sido aprovechada para canalizar las conducciones de agua y alcantarillado del núcleo de los Baños de Sierra Alhamilla, por lo que se han construido unos soportes metálicos, tanto en este puente como en el siguiente. No es posible transitarlo y, por ello, hay que retroceder unos metros para bajar por el terraplén de la vía y llegar a la rambla, desde donde se contempla una vista majestuosa de esta obra civil. Llegados a este punto, resulta imposible seguir sin mencionar que en 1961 sirvió de decorado cinematográfico para el primer western filmado en tierras almerienses, Tierra brutal, donde tiene lugar una de las muchas escenas rodadas en estos parajes ferroviarios. Pero esto no quedó en una simple anécdota, sino que todo el entorno de la cabecera de la estación de El Chorrillo ha servido en muchas ocasiones como escenario natural y lugar donde montar distintos decorados de diversas películas de cine y televisión, así como anuncios publicitarios. Sirvan de ejemplo títulos como El Evangelio de Juan, Las pistolas no discuten, El Halcón y la presa, Tú perdonas... yo no, Las maletas de Tulse Luper o Hermanos.

A partir del paso de este cauce, el trazado discurre en trinchera por la margen izquierda de la denominada rambla de San Indalecio, a una altura respetable de su lecho, por lo que no se puede acceder hasta unos metros aguas abajo, salvo que queramos subir con cierto riesgo. Una vez retomada la explanación, es muy interesante volver hacia el puente para contemplar las hermosas vistas de toda Sierra Alhamilla y tener una idea del desnivel que tuvo que afrontar este ferrocarril. También, es muy probable toparse con lagartos, culebras de respetable tamaño y distintas aves que sobrevuelan la traza.

Si se hace el recorrido en bicicleta hay que tener precaución con el terreno irregular y los pequeños derrumbes o corrimientos de tierra, fruto de la erosión y el paso de los años. Además, al ser descendente, se va cogiendo velocidad sin querer. Esta zona es quizás la más "ferroviaria" del trazado al discurrir en trinchera 


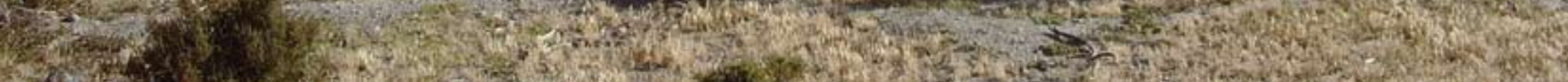
X.t.

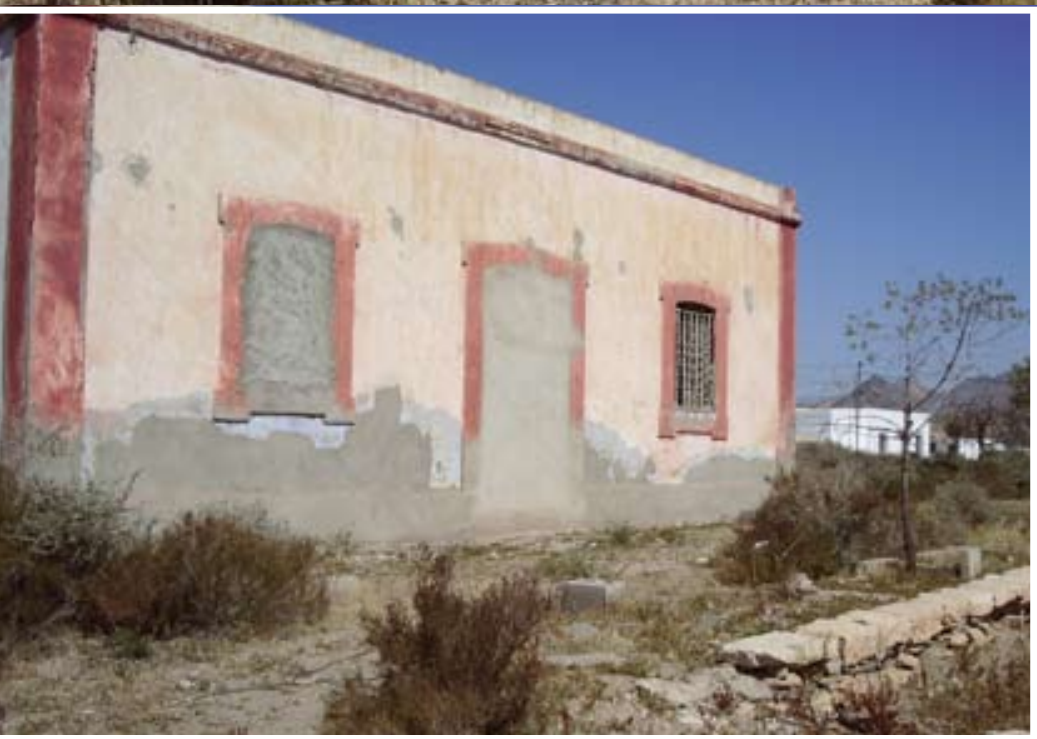

Viviendas de obreros en El Chorrillo. Fuente: Fondo ASAFAL

Estación de Pechina vista desde el andén. Fuente: Fondo ASAFAL

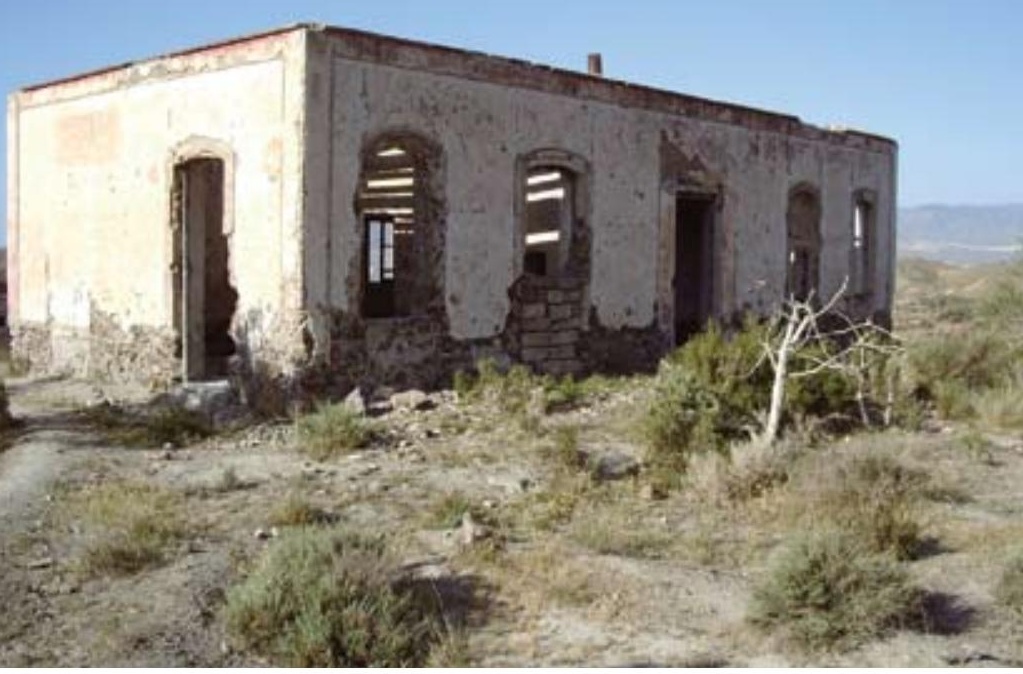

Estado actual del edificio de viajeros de El Chorrillo. Fuente: Fondo ASAFAL 


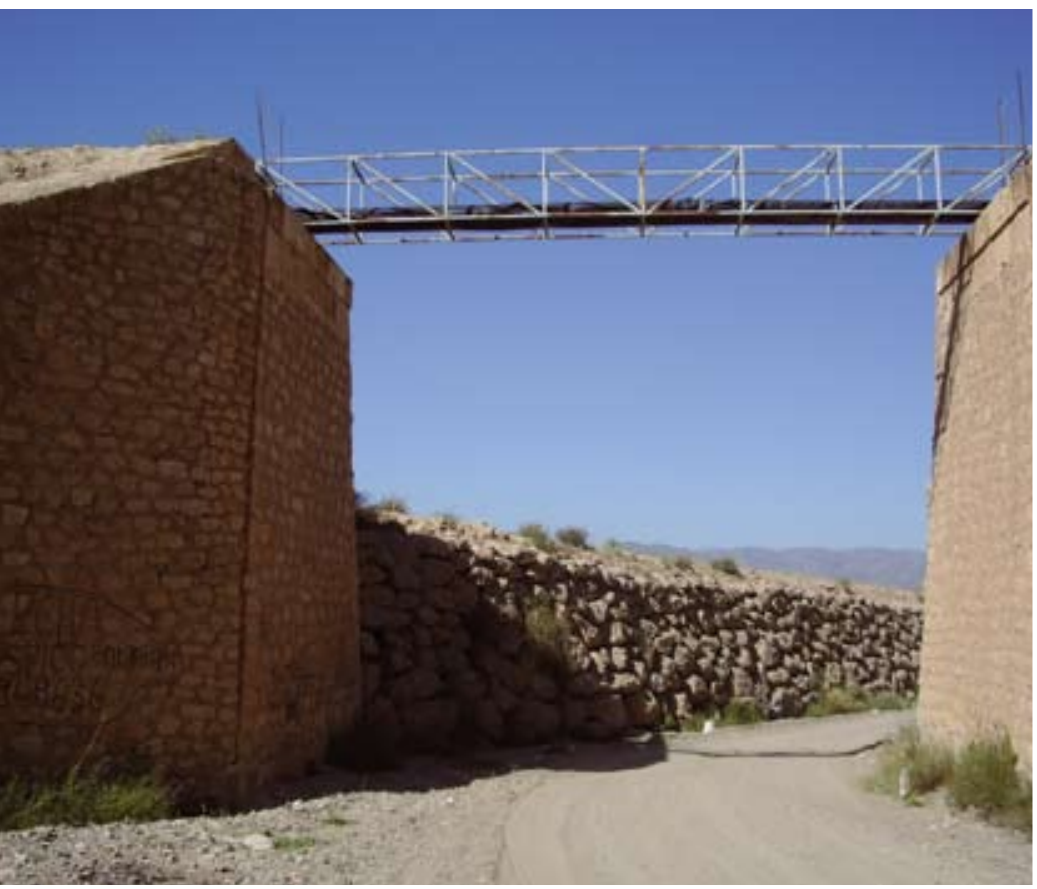

Puente de la rambla de Ayuso. Fuente: Fondo ASAFAL

antes de llegar al siguiente puente que atraviesa otra rambla, la denominada Ayuso. En este punto, se divisa perfectamente la costa y, como un castillo en un altozano, el edificio del hospital de Torrecárdenas de Almería. Al igual que el anterior puente, aquí se precisa desandar lo andado unos metros para bajar al lecho seco y pasar al otro lado, aunque, en este caso, ya entramos en una zona agrícola con invernaderos y la traza es aprovechada como camino rural asfaltado. Los sólidos estribos del puente soportan la leve y fea estructura metálica que albergan las conducciones de la red de agua y alcantarillado que termina en la próxima depuradora. El único tablero metálico que soportaba el paso de los trenes tenía una longitud de 10,60 m y sólo permanecen los estribos de mampostería.

Pasar al otro extremo del puente requiere dar un gran rodeo por un camino asfaltado, porque toda la margen izquierda de la rambla ha sido reforzada con grandes bloques de piedra para consolidar el terreno e impide una subida directa. En cualquier caso, aquí se puede dar por finalizado el tramo más "virgen" de este antiguo ferrocarril, porque, como ya se indicaba anteriormente, desde este punto la explanación se pierde casi por completo. Esa frontera, entre la parte alta y la baja estaría en el parque periurbano ubicado junto a una depuradora de aguas residuales que, posiblemente, destruyera el trazado original al realizar el desmonte y movimientos de tierras previo a su construcción. A partir del parque se puede continuar por la traza asfaltada para llegar a la estación de Pechina, o lo que queda de ella: un edificio de una sola planta que se asemeja más a una vivienda que a lo que entendemos por una estación de ferrocarril. Los restos del pequeño andén y un respiradero de una mina de agua (qanat árabe), protegida con un mallazo metálico debajo

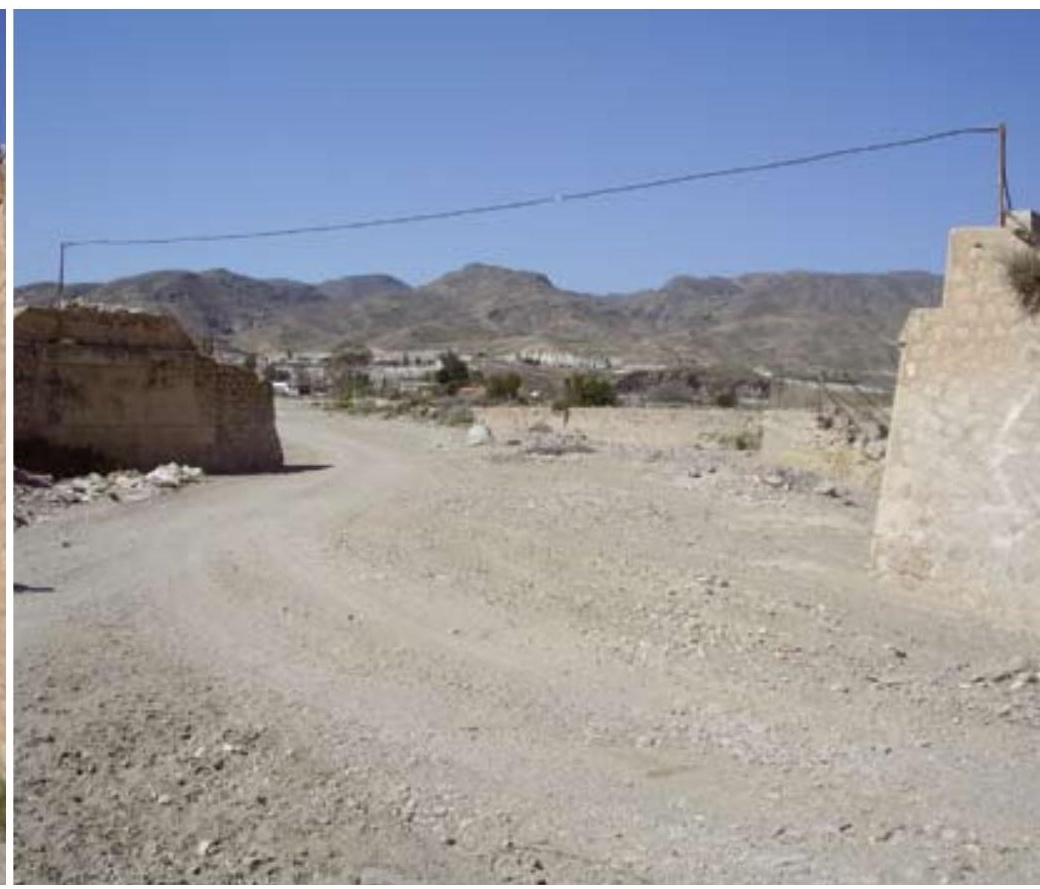

Puente de la rambla Carrillo. La pilastra de apoyo intermedio ha desaparecido. Fuente: Fondo ASAFAL

del cual todavía permanecen unos carriles, posiblemente de la propia línea, nos invitan a descansar.

Para continuar, es preciso seguir en línea recta por un camino de tierra e imaginar que, entre lo que hoy son bancales medio abandonados, iria el trazado ferroviario. Este camino va paralelo al mismo porque, entre algunos cortijos, se divisan los estribos del puente de la rambla de Parra, similar a la de Ayuso, y que nos da una idea de la ubicación de la explanación original.

El camino termina en la rambla de Carrillo, donde podemos observar un nuevo puente para salvar el cauce. Con una longitud de 21,40 m, estaba dividido en dos tramos metálicos con una pilastra central de sillería de apoyo, hoy desaparecida, subsistiendo solamente los estribos.

Ya resulta imposible volver al trazado ferroviario, porque, sencillamente, no existe, por lo que hay que descender por la misma rambla de Carrillo para desembocar en el cauce del río Andarax $y$, pocos metros aguas abajo, toparse con lo que en su día fue un magnífico puente metálico de $90 \mathrm{~m}$ del que sólo quedan los basamentos de piedra de cantería y los estribos de ambos lados. Este fue el punto más conflictivo que tuvieron que sortear los ingenieros que construyeron el ferrocarril minero y, por eso, optaron por un puente metálico dividido en nueve tramos de 7,70 y dos de 9,70 m, apoyados sobre columnas tipo phoenix arriostradas (eran iguales en los puentes anteriores que tenian apoyos) en pilastras de mamposteria, que facilitaban el paso de los trenes con las máximas garantías en las épocas de fuertes Iluvias y de riadas. Cumplió perfectamente su cometido y pudo seguir prestando un servicio eficaz una vez cesó la explotación 


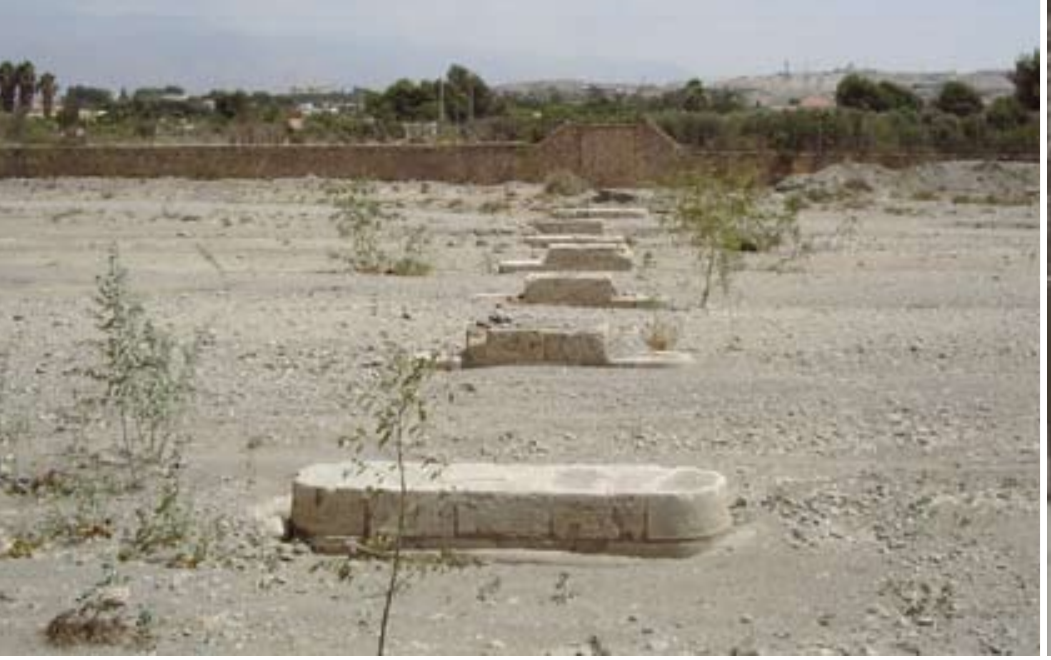

Vestigios del puente del río Andarax. Pilastras de apoyo y estribos de mampostería. Fuente: Fondo ASAFAL

del ferrocarril. En 1942, el Ayuntamiento de Almería obtuvo el permiso para recuperar los tramos metálicos de este puente y de otros para construir dos pasarelas peatonales y un puente carretero sobre la rambla de Belén en la capital almeriense, con lo que conseguian un aprovechamiento total de los materiales en una época muy difícil y de escasez. Con motivo de la reurbanización de esta rambla, a comienzos de la década de los noventa del siglo XX, fue desmontado el puente de la calle Santos Zárate - Paco Aquino (antes habian sido retiradas las pasarelas peatonales de la rambla de Obispo Orberá y de la calle Alcalde Muñoz) y con ello terminó una vida centenaria, primero ferroviaria y después urbana.

Aqui finaliza el recorrido, cuando atraviesa el río Andarax para dirigirse por su margen derecha hasta Almería, pasando por Huércal de Almeria, de cuya estación no queda nada, y discurrir paralelo a la actual linea del ferrocarril de Linares a Almería. Toda esta zona está muy alterada, bien sea por explotaciones agrarias o por viviendas, aunque es de suponer que algunos de los caminos que surcan estos parajes formen parte del antiguo trazado ferroviario, como sucede con la ya mencionada carretera de Sierra Alhamilla de la capital.

Hemos perdido una parte importante del trazado original, pero todavía queda el recorrido más agreste y espectacular para su disfrute. Quizás no esté en las mejores condiciones, pero es posible que, si lo recorremos, conocemos su historia y la divulgamos, seamos capaces de recuperar lo que un día fue sinónimo de progreso.

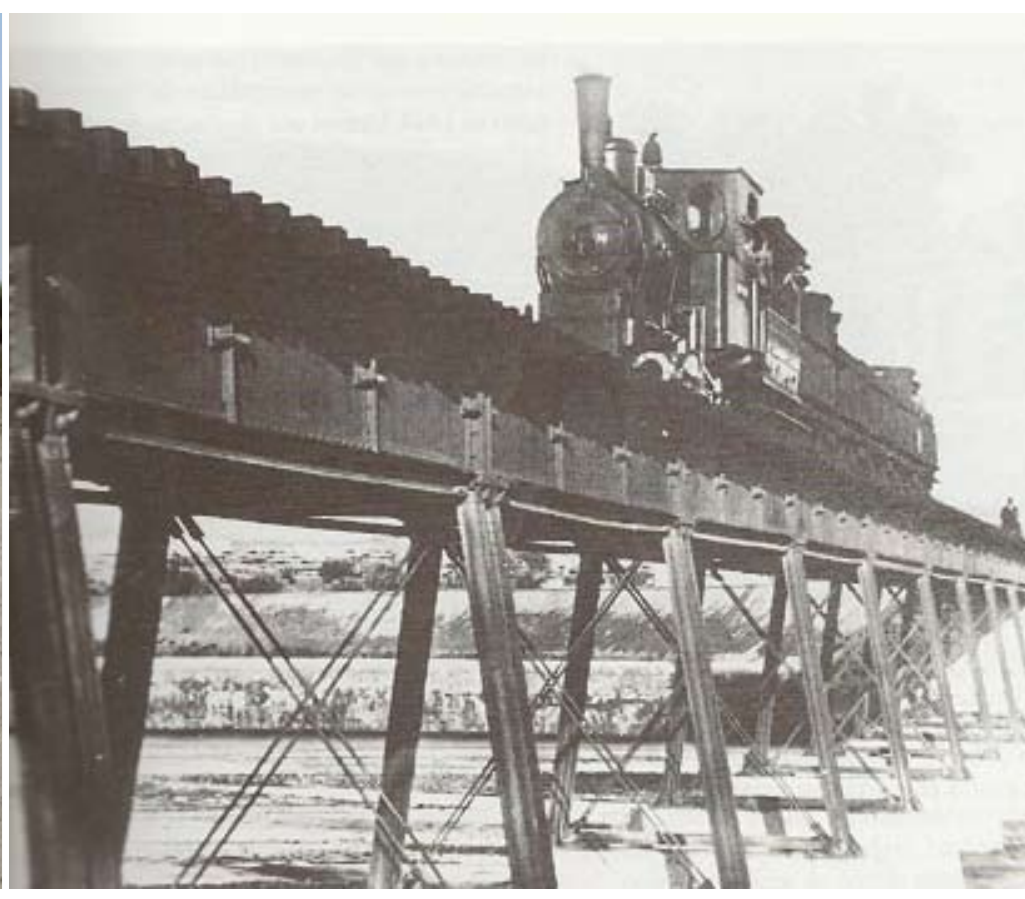

Paso de un tren por el puente del río Andarax. Fuente: Instituto de Estudios Almerienses

\section{Su existencia fue azarosa desde su misma gestación y tuvo una vida corta, sin embargo, nos ha quedado un legado patrimonial que deberíamos proteger del deterioro físico y del olvido}




\section{Datos de base de Andarax y Campo de Tabernas}

La zona del Andarax y el Campo de Tabernas comprende treinta y siete términos municipales de la provincia de Almeria. Veinticuatro de estos municipios se integran completamente en la zona estudiada: Abla, AlboIoduy, Alhabia, Alsodux, Benahadux, Benizalón, Castro de Filabres, Gádor, Gérgal, Huércal de Almería, Nacimiento, Olula de Castro, Pechina, Rioja, Santa Cruz, Santa Fé de Mondújar, Senés, Tabernas, Tahal, Las Tres Villas, Turrillas, Uleila del Campo, Velefique y Viator'.

Hay otros trece municipios integrados solo parcialmente: Abrucena, Alhama de Almería, Alicún, Almería, Bédar, Bentarique, Fiñana, Huécija, Lubrín, Lucainena de las Torres, Sorbas, Terque y Turre.

En esta zona se han localizado un total de 554 inmuebles, de los cuales el 63\% corresponden al patrimonio arqueológico, el 26\% al patrimonio arquitectónico y el $11 \%$ al patrimonio etnológico.

El motivo de que el número de inmuebles mas alto sea el correspondiente al patrimonio arqueológico puede deberse por una parte, a que este se localiza casi exclusivamente mediante coordenadas, y por otra parte a que en Andalucía oriental la presencia humana en la Prehistoria reciente es muy fuerte, ya que desde el Neolitico comienzan a establecerse asentamientos utilizando sobre todo las cuencas de los ríos Andarax y Nacimiento con el consiguiente aprovechamiento del agua para la agricultura. Asi tenemos grandes poblados, algunos fortificados como Los Millares, que es más importante de la zona, Las Juntas en Abla, La Umbría en Gérgal o Los Álamos en el Campo de Tabernas.

Junto a estas poblaciones se encuentran gran número de construcciones megaliticas como Los Milanes en Abla, o la Necrópolis Megalítica de Gádor.
También abundan los sitios con manifestaciones rupestres que se localizan sobre todo en los municipios de Gérgal y Nacimiento.

En cuanto al patrimonio arquitectónico la mayor parte de los registros que están localizados en el mapa corresponden a los inmuebles protegidos, sobre todo los que se encuentran dentro del Centro Histórico de Almeria; inmuebles pertenecientes al Registro Andaluz de Arquitectura Contemporánea (RAAC); inmuebles procedentes del Inventario de Cortijos, Haciendas y Lagares, asi como la arquitectura defensiva.

El patrimonio etnológico se encuentra representado en su mayor parte por los cortijos dedicados tradicionalmente al cultivo y transformación de la uva, aunque actualmente casi todos han perdido esa función y se dedican al cultivo de frutales, cereales y otras actividades agropecuarias. Junto a estos se registran también lagares y bodegas, asi como otros inmuebles relacionados con el aprovechamiento del agua como norias, aljibes, boqueras, etc.

Desde el punto de vista de las tipologías funcionales y los periodos históricos a los que se asocia el patrimonio inmueble de la zona estudiada, se han utilizado los términos del Tesauro de Patrimonio Histórico Andaluz agrupándolos de la siguiente manera:

-Edificaciones productivas: los inmuebles pertenecientes a esta tipología suponen un $17 \%$ del total.

-Edificaciones dotacionales, que agrupa distintas tipologías como las construcciones funerarias, sanitarias, de espectáculo, etc. Los inmuebles pertenecientes a esta tipologia suponen un $38 \%$ del total.
- Asentamientos y espacios libres: los inmuebles pertenecientes a esta tipología suponen un $23 \%$ del total.

- Edificaciones militares: los inmuebles pertenecientes a esta tipología suponen un $9 \%$ del total.

- Edificaciones religiosas: los inmuebles pertenecientes a esta tipología suponen un 5\% del total.

- Edificaciones residenciales: los inmuebles pertenecientes a esta tipología suponen un $5 \%$ del total.

- Sitios con representaciones rupestres: los inmuebles pertenecientes a esta tipología suponen un 3\% del total.

Entre los periodos históricos destaca la Prehistoria reciente con 269 inmuebles; le sigue la Edad Media con 110 inmuebles, casi todos pertenecientes a la arquitectura defensiva; después están los inmuebles de la Edad Contemporánea, entre los que se encuentran los pertenecientes al RAAC y al Inventario de Cortijos, Haciendas y Lagares; de Época Romana se cuentan 76 inmuebles, de los que la mayoría son asentamientos y villae; de la Protohistoria, 19; y de la Edad Moderna 28.

Pilar Mondéjar Fernández de Quincoces Salud Soro Cañas

Centro de Documentación y Estudios del Instituto Andaluz del Patrimonio Histórico

\section{Notas}

' La información de carácter patrimonial contenida en el Sistema de Información para la Gestión Integral del Patrimonio Cultural relativa a la zona de Andarax y el campo de Tabernas se analiza en base al patrimonio inmueble que se haya localizado cartográficamente en la misma.

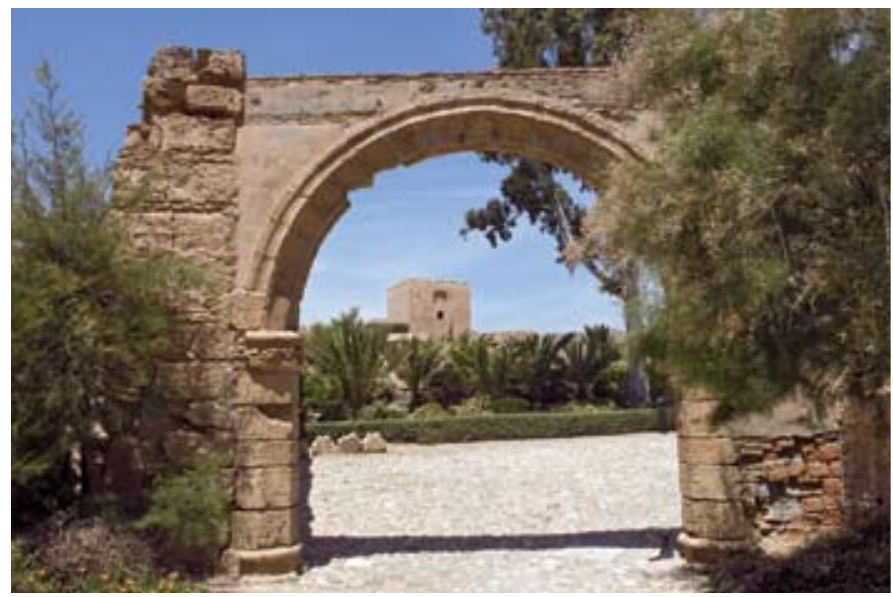

Conjunto Monumental de la Alcazaba de Almería Foto: Juan Carlos Cazalla, IAPH

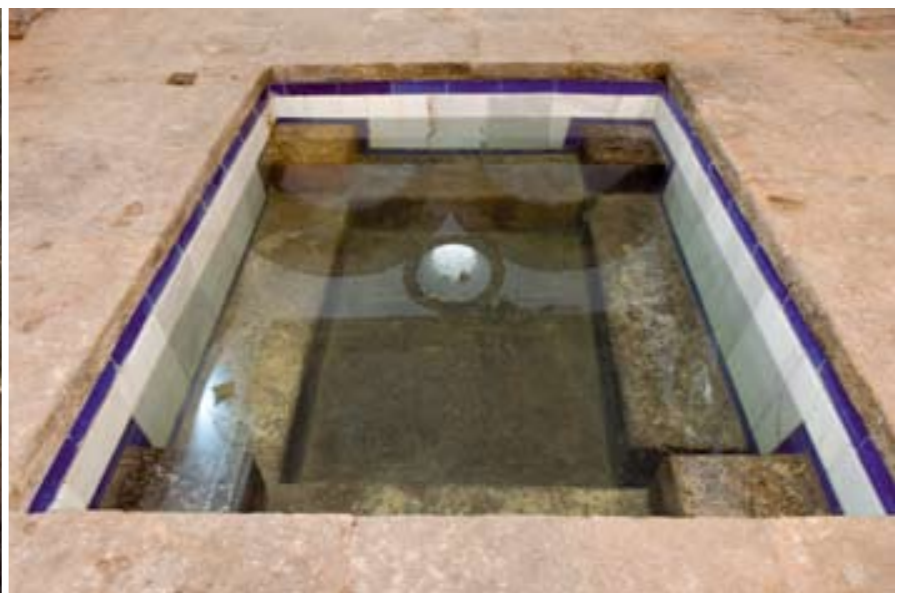

Instalaciones del balneario de Sierra Alhamilla.

Foto: Juan Carlos Cazalla, IAPH 

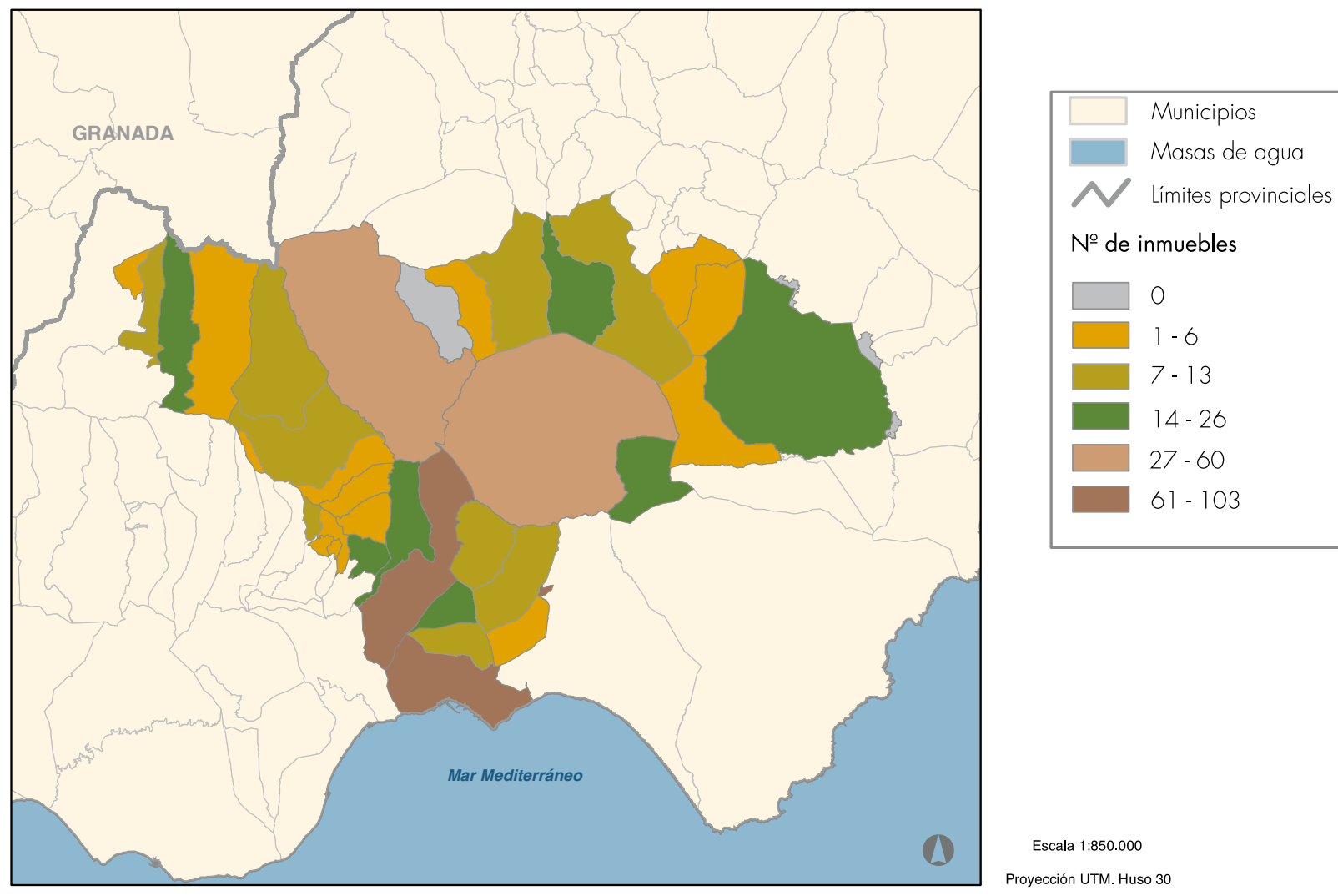

№ de inmuebles

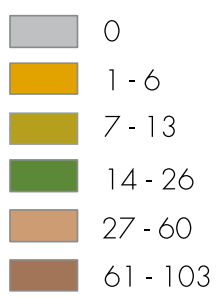

Escala 1:850.000

Proyección UTM. Huso 30

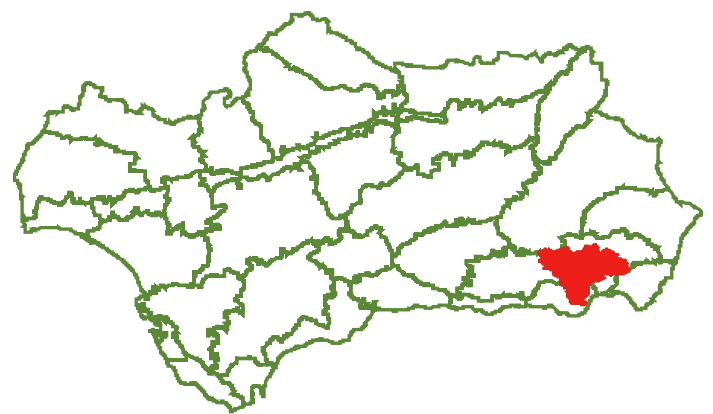

Gráfico 1. Localización del área

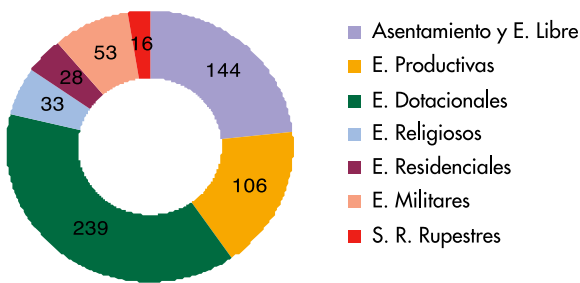

Gráfico 3. Tipologías funcionales

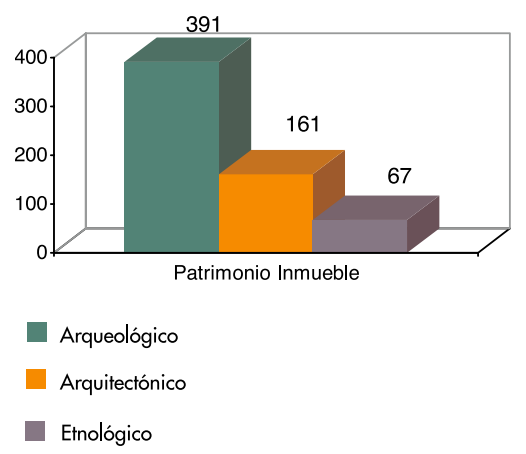

Gráfico 2. Distribución por tipo

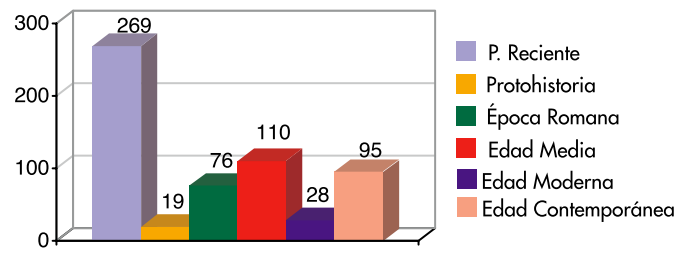

№ inmuebles

Gráfico 4. Periodos históricos 


\section{El Catálogo General del Patrimonio Histórico Andaluz en Andarax y Tabernas}

De los 37 municipios regados por los valles de Tabernas y río Andarax, 24 de ellos poseen bienes patrimoniales incluidos en el Catálogo General del Patrimonio Histórico Andaluz.

Si los clasificamos por la figura legal que les da protección, nos encontramos con 17 bienes de Catalogación General y 59 Bienes de Interés Cultural. De estos, la tipología que predomina son los Monumentos, con 47 bienes, seguido de las Zonas Arqueológicas, representadas por 9, y el Conjunto Histórico de Almería.

Entre los expedientes de protección como Bien de Interés Cultural efectuados en esta área, habría que señalar dos grandes Zonas Arqueológicas que destacan tanto por su amplitud territorial como por su valor patrimonial: Los Millares, considerado como uno de los yacimientos calcolíticos más importante de Europa, fue declarado ya en 1931 como Monumento Histórico-Artístico, aunque su delimitación, en la cual se incluyen 15 fortines y la necrópolis con más de 100 tumbas colectivas, no se efectuaria hasta el Decreto 112/1996, de 12 de marzo de 1996.
La otra Zona Arqueológica destacable es la Necrópolis Megalítica de Gádor declarada por el Decreto 194/2007, de 26 de junio de 2007. Esta zona arqueológica engloba sesenta sepulturas documentadas de cámara rectangular o poligonal, con túmulo de cubierta, repartidas en siete yacimientos arqueológicos. La Necrópolis de Gádor responde a todo un complejo de poblados que sigue el valle del río Andarax, y que tiene como centro neurálgico el asentamiento de Los Millares y su necrópolis.

Desde principios del siglo XIX hasta mediados del siglo $X X$, en la provincia de Almería se intensificó la explotación de los recursos mineros ejercida ya desde época antigua debido a la riqueza minera del territorio. Esta actividad iba acompañada de una arquitectura industrial que destaca no sólo por sus valores históricos, sino también testimoniales, sociales, paisajisticos, científicos y técnicos.

Desde el Servicio de Protección del Patrimonio Histórico de la Dirección General de Bienes Culturales, se ha propiciado la protección de dichos bienes mediante Resolución de 7 de enero de 2004, por la que se resuelve inscribir colectivamente con carácter genérico en el Catálogo General del Patrimonio Histórico Andaluz 44 Bienes Inmuebles pertenecientes al Patrimonio industrial relacionados con la minería de los siglos XIX y XX en la provincia de Almería.

Según lo que establece la Disposición adicional segunda de la Ley 14/2007, de 26 de noviembre, de Patrimonio Histórico de Andalucía, los bienes inscritos con carácter genérico en el Catálogo General del Patrimonio Histórico Andaluz tendrán la consideración de bienes de catalogación general. De este expediente, 11 bienes de catalogación general se encuentran en la zona del Andarax y valle de Tabernas, incluyendo cinco puentes ferroviarios, distintivos de las ramblas y rios que modelan este paisaje almeriense de extensa historia y riqueza patrimonial.

Olga Viñuales Meléndez Alfonso Montejo Ráez

Servicio de Protección del Patrimonio Histórico Dirección General de Bienes Culturales

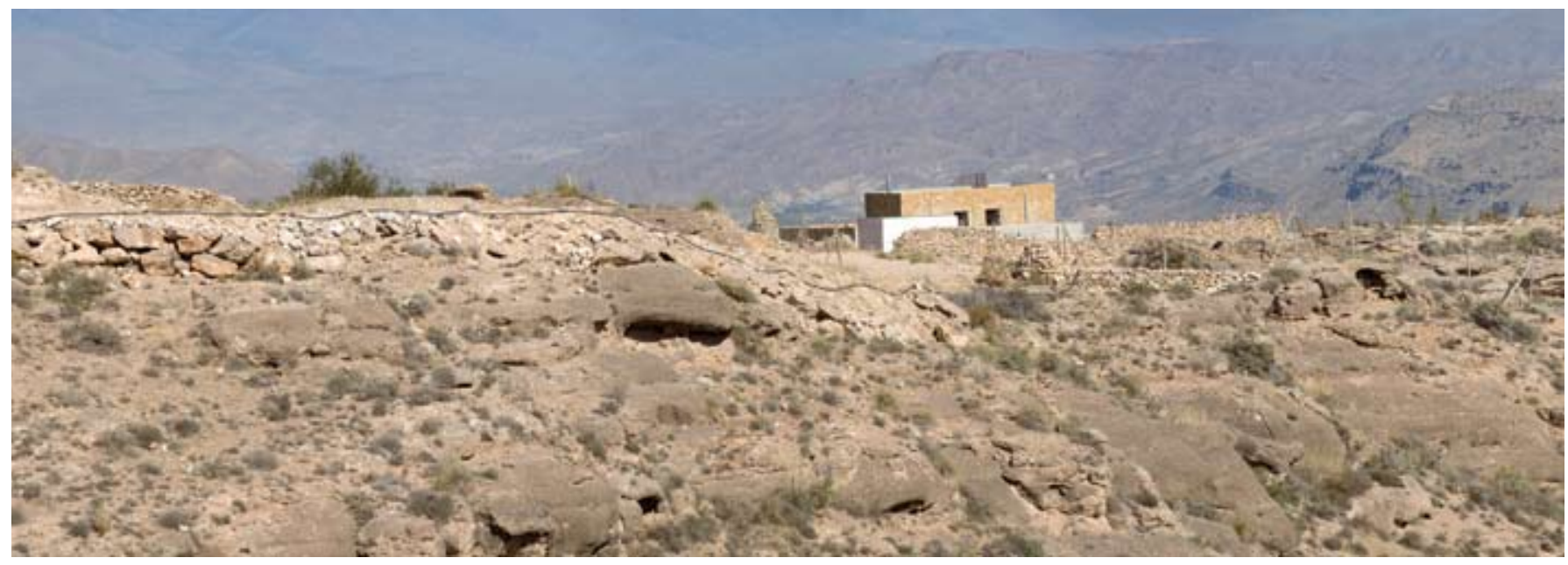

Yacimiento arqueológico de Loma Galera en Alhama de Almería. Foto: Juan Carlos Cazalla, IAPH

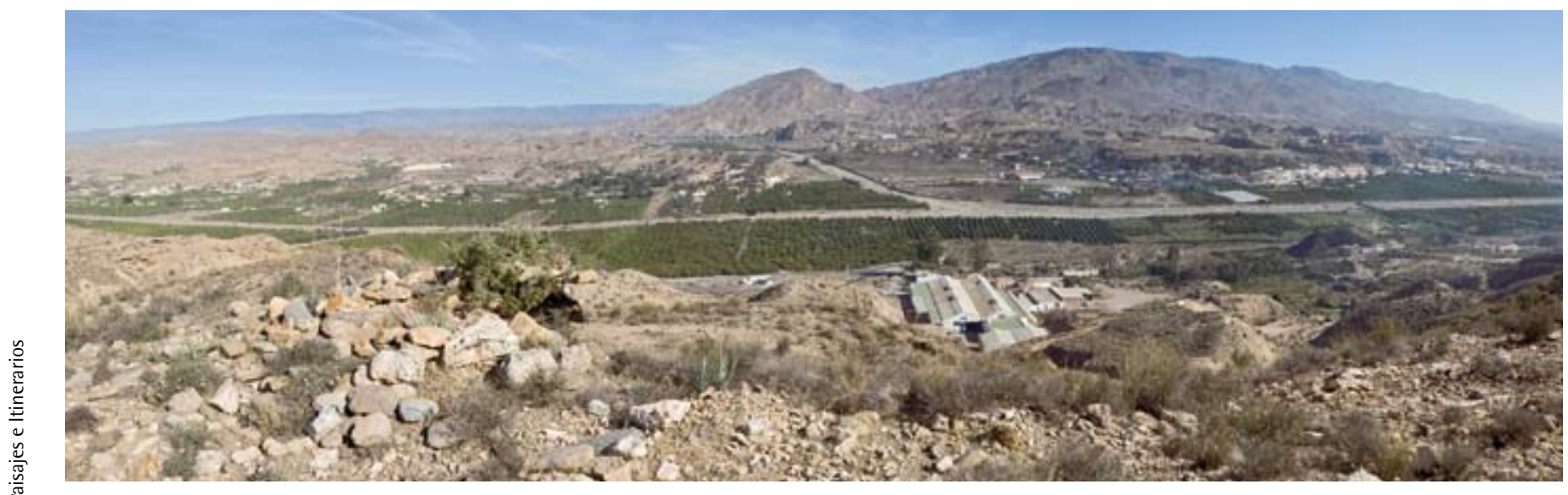

Vista del Valle del Andarax desde el término de Gádor. Al fondo a la derecha, Rioja. Foto: Juan Carlos Cazalla, IAPH 

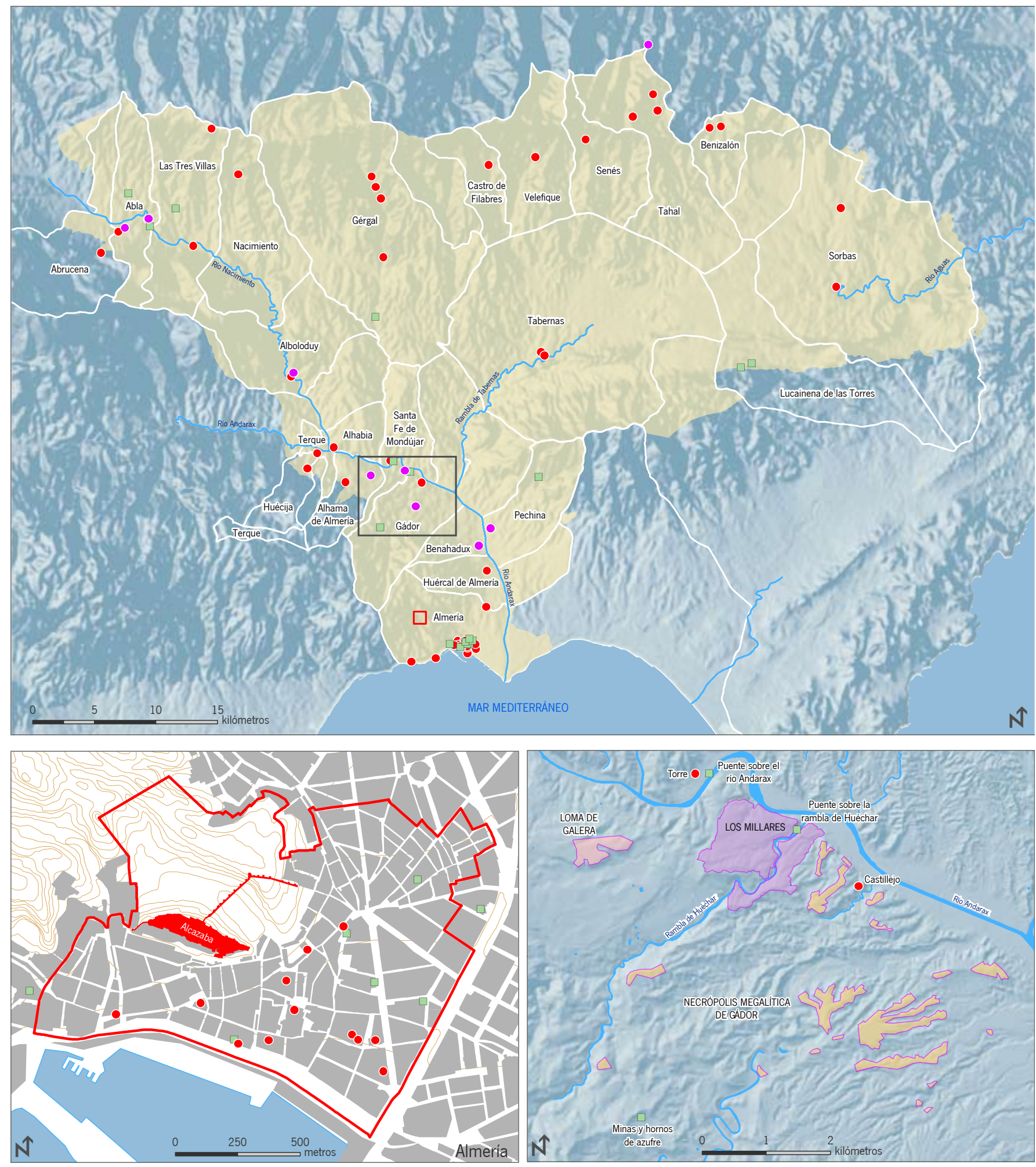

Bien de Interés Cultural Tipología:

- Monumento

- Zona Arqueológica

Bien de Catalogación General
El Catálogo General del Patrimonio Histórico Andaluz en los valles de Andarax y Tabernas (Almería)

Cartografía base: Mapas Topográficos de Andalucía 1:100.000 (2005) y 1:10.000 (2002), y Modelo Digital del Terreno de Andalucia (2005), Instituto de Cartografia de Andalucia 
ACIÉN ALMANSA, M. (2005) La Alcazaba de Almeria durante los siglos IX-XI: cuestiones históricas y arqueológicas. En La Alcazaba, fragmentos para una historia de Almería. Sevilla: Consejería de Cultura, Junta de Andalucia, 2005, pp. 77-87

ACIÉN, M.; CASTILLO, F.; MARTÍNEZ, M. (1990) Excavación de un barrio artesanal de Bayyana (Pechina- Almería). Archéologie Islamiqué 1, 1990, pp.147-168

AGUILAR, C. (1999) Joaquin Romero Marchent. La firmeza del profesional. Almería: Diputación de Almería, 1999

AGUILAR, C. (2001) El cine en Almeria: el paisaje es el mensaje. Cuadernos de la Academia, no 10, 2001, pp. 327-341

AGUILAR, C. (2009) Sergio Leone. Madrid: Cátedra 2009

ALCARAZ, F. [et àl] (1994) Prospección arqueológica superficial en el Pasillo de Tabernas. Primeros resultados y perspectivas metodológicas. En KUNST, M. (coord.) Origens, estruturas e relaçôes das Culturas calcolíticas da Península Ibérica (Actas das I Jornadas Arqueológicas de Torres Vedras 3-5 abril 1987). Trabalhos de Arqueologia 7, 1994, pp. 217-223

ALMAGRO, M.; ARRIBAS, A. (1963) El poblado y la necrópolis megalitica de Los Millares (Santa Fe de Mondújar, Almeria). Madrid: Biblioteca Praehistorica Hispanica III, 1963 *

AMATE RODRÍGUEZ, M.C. (2007) Alhama de Almería, perfil de su historia. Almería: Ayuntamiento de Alhama de Almería, 2007

ARAUS, J.L [et ál] (1997) Changes in carbon isotopes discrimination in grain cereals from Catalonia and eastern Andalusia during the past seven millennia. Palaeoenvironmental evidence of a differential change in aridity during the late Holocene, Global Change Biology, 3 (1997), pp. 107-118

ARRIBAS, A., [et ál] (1987) Informe preliminar de los resultados obtenidos durante la VI Campaña de excavaciones en el poblado de Los Millares (Santa Fe de Mondújar, Almeria, 1985), Anuario Arqueológico de Andalucía 1985:II, Sevilla (1987), pp. 245-262

BASE de datos del Patrimonio Inmueble de Andalucía (SIPHA), Instituto Andaluz del Patrimonio Histórico, Consejería de Cultura, Junta de Andalucía [en línea], (http://www.juntadeandalucia.es/cultura/ iaph/bdi/frmSimple.do) [consulta: 26/10/2009] *
BONET, J. [et ál] (2006) Guillermo Langle Rubio: arquitecto de Almería: 1895-1981. Sevilla: Consejería de Obras Públicas y Transportes, Dirección General de Arquitectura y Vivienda, 2006

\section{CÁMARA SERRANO, J. A.; MOLINA GONZÁLEZ, F.} (2004) El megalitismo en el sureste de la Peninsula Ibérica. Ideología y control territorial. En MARQUÉS I.; GONTÁN, Ma. C.; ROSADO, V. (coord.) Mainake XXVI. Los enterramientos en la Península lbérica durante la Prehistoria Reciente, 2004, pp. 139-163

CAPARRÓS MASEGOSA, L.; FERNÁNDEZ MAÑAS I.; SOLER, J. (1997) La producción cinematográfica en Almería (1951-1975). Almería: Instituto de Estudios Almerienses, 1997 *

\section{CAPARRÓS MASEGOSA, L.; FERNÁNDEZ MAÑAS}

I. (2001) Cine y franquismo en Almeria: 1940-1959. En Actas del Congreso Dos décadas de cultura artística en el franquismo (1936-1956), vol. I. Granada: Proyecto Sur, 2001, pp. 385-398

CARA BARRIONUEVO, L. (2005) Balad Qasabat AIMariyya: La madina de la Alcazaba de Almeria. En La Alcazaba, fragmentos para una historia de Almería. Sevilla: Consejería de Cultura, Junta de Andalucia, 2005, pp.113-124

CARA, L.; RODRíGUEZ, J. Ma. (1984) Análisis de distribución espacial de las comunidades megalíticas en el valle del río Andarax (Almería), Coloquio sobre distribución y relaciones entre los asentamientos 3 (Teruel, 1984), Arqueología Espacial 3, Del Epipaleolítico al Bronce Medio, Teruel, 1984, pp. 53-75

\section{CARA BARRIONUEVO, L.; RODRÍGUEZ LÓPEZ, J.}

M. (1998) Introducción al estudio crono-tipológico de los castillos almerienses En MALPICA CUELLO, A. (ed). Castillos y territorio en Al-Andalus. Granada: Athós-Pérgamos, 1998, pp.164-245*

CARA BARRIONUEVO, L. (2006) La Alcazaba de Almería, un monumento para la historia de una ciudad. Almería: Instituto de estudios almerienses, 2006

CARA BARRIONUEVO, L.; SÁNCHEZ RAMOS, V.; GIL ALBARRACíN, A. (2007) Castillos, Fortificaciones y Defensas. Almeria: Instituto de estudios almerienses, 2007*

CHAPMAN, R. W. (1991) La formación de las sociedades complejas. La Península lbérica en el marco del Mediterráneo Occidental. Barcelona: Crítica, 1991

\section{CIFUENTES VÉLEZ, E; LÓPEZ GÓMEZ, J. F. (2006)}

Delimitación del BIC y entorno de la Alcazaba de Tabernas, Almería. Sevilla: Consejería de Cultura. Junta de Andalucia, 2006 (documentación técnica inédita)
CIFUENTES VÉLEZ, E; LÓPEZ GÓMEZ, J. F. (2006) Delimitación del BIC y entorno del Castillejo de Gádor, Almería. Sevilla: Consejeria de Cultura. Junta de Andalucía, 2006 (documentación técnica inédita)

CIFUENTES VÉLEZ, E; LÓPEZ GÓMEZ, J. F. (2002) Delimitación de entornos de monumentos: Torre de Santa Fe de Mondújar, Almería. Sevilla: Consejería de Cultura. Junta de Andalucia, 2002 (documentación técnica inédita)

CRESSIER, P. (2005) La Almería islámica: un paisaje de castillos. En La Alcazaba, fragmentos para una historia de Almería. Sevilla: Consejería de Cultura, Junta de Andalucia, 2005, pp.45-56

DÍAZ RAMOS, A. (1996) Gádor. En Almería pueblo o pueblo. Madrid: Mediterráneo, 1996, pp. 297-300

ESQUIVEL, J.A.; NAVAS, E. (2005) The geometry and the metric used in the enclosure "Fortin 1" at Copper Age site of Los Millares (Almería, Andalusia), Journal of Archaeological Science, 32 (2005), pp. 1577-1586

FERNÁNDEZ MAÑAS, I. (1997) Gil Parrondo: pasión y rigor. Almeria: Ed. II Festival Nacional de Cortometrajes "Almería, Tierra de Cine" y Diputación de Almería, 1997

FERNÁNDEZ MAÑAS, I. (1998) El cine en Almería durante el franquismo. En W.AA. La Historia de Almería. Memorias del tiempo, vol. II. Almería: Mediterráneo-Agedime y Novotécnica-La Voz de Almería (1998), pp. 378-384

FERNÁNDEZ MAÑAS, I. (2002) Almeria en la obra de Gil Parrondo. Nickel Odeon, no 27 (2002), pp. 188-193

FERNÁNDEZ SÁEZ, A.; AGUIRRE SEGURA, B. (1998) Los Baños de Sierra Alhamilla. Pasado, presente y futuro. Almeria: Diputación Provincial de Almería, 1998

GABERSCEK, C. (2005) Cinema western in Almería Udinese: Lithostampa, 2005

GABERSCEK, C. (2007) // vicino west. Udinese: Lithostampa, 2007

GARCIA CAMPRA, E. (1996) Aguas y baños de Alhama de Almeria. El Eco de Alhama, no 1, julio, 1996

GÓMEZ MARTÍNEZ, J. A.; COVES NAVARRO, J. V. Trenes, cables y minas de Almería. Almería: Instituto de Estudios Almerienses, 2000 
GURRIARÁN, P; MÁRQUEZ, M. (2005) La Almería medieval como fortaleza. En La Alcazaba, fragmentos para una historia de Almería. Sevilla: Consejería de Cultura, Junta de Andalucía, 2005, pp. 59-73

GUSI, F. (1986) El yacimiento de Terrera Ventura (Tabernas) y su relación con la Cultura de Almería, Homenaje a Luis Siret (1934-1984), Consejería de Cultura, 1986, pp. 192-195*

HOWARD, E. (1965) Garden Cities of Tomorrow. Massachusetts: The M.I.T. Press, 1965

LEISNER, G.; LEISNER, V. (1943) Die Megalithgräber der Iberischen Halbinsel. Der Süden, RömischGermanische Forschungen, 17 (1943)

LIROLA DELGADO, J. (1992-1993) Una hipótesis sobre la construcción de la cerca de al-Mudayna en el actual cerro de San Cristóbal (Almeria), Boletín del Instituto de Estudios Almerienses, 7-19, 1992-1993

MALPICA CUELLO, A. (2002) Los castillos en A/Andalus y la organización del territorio. Cáceres: Universidad de Extremadura, 2002 *

MÁROUEZ ÚBEDA, J. (1999) Almería, plató de cine. Almería: Instituto de Estudios Almerienses, 1999

MARTÍNEZ MOYA, J. E. (1999) Almería, un mundo de película. Almeria: Instituto de Estudios Almerienses, 1999

MOLINA, E. (2005) Historia de una prosperidad quebrada. En La Alcazaba, fragmentos para una historia de Almería. Sevilla: Consejeria de Cultura, Junta de Andalucia, 2005, pp.15-41

MOLINA, F.; CÁMARA, J.A. (2005) Guía del yacimiento arqueológico Los Millares, Empresa Pública de Gestión de Programas Culturales, Consejeria de Cultura. Junta de Andalucía, 2005 *

MOMO Andalucía: arquitectura del movimiento moderno en Andalucía 1925-1965 (1999) Sevilla: Consejeria de Obras Públicas y Transportes, 1999 *

MUÑOZ BUENDíA, A. (1996) Benahadux. En Almería pueblo a pueblo. Madrid: Mediterráneo, 1996, pp. $173-180$

NAVAS, E.; ESOUIVEL, J.A.; MOLINA, F. (2008) Butchering Patterns and Spatial Distribution of Faunal Animal Remains Consumed at the Los Millares Chalcolithic Settlement (Santa Fe de Mondújar, Almeria, Spain). Oxford Journal of Archaeology 27:3 (2008), pp. 325-339
PÉREZ SIQUIER, C. (1956) Cine. Entrevista a Cayatte. Afal, año I, nº 5 (1956)

PETERS, J.; DRIESCH, A. von den (1990) Archäozoologische untersuchung der tierreste aus der kupperzeitlichen siedlung von Los Millares (Prov. Almeria), Studien über frühe Tierknochenfunde von der Iberischen Halbinsel, 12, 1990, pp. 49-110

RODRÍGUEZ, M.0.; VERNET, J.L. (1991) Premiers résultats paléocarpologiques de l'établissement Chalcolithique de Los Millares, Almeria, d'après I'analyse anthracologique de l'établissement, 2nd Deya International Conference of Prehistory. Recent developments in Western Mediterranean Prehistory: Archaeological techniques, technology and theory. Vol. I. Archaeological techniques and technology. En WALDREN, W.H.; ENSENYAT, J.A., KENNARD R.C. (ed.), British Archaeological Reports. International Series, 573, 1991, pp. 1-16

ROMERO GRANADOS, F. (1996) Santa Fe de Mondújar. En Almería pueblo a pueblo. Madrid: Mediterráneo, 1996, pp. 509-512

RUIZ GARCíA, A. (2009) Itinerario por un territorio singular. Almeria: Mancomunidad de Municipios del Bajo Andarax, 2009

SEGURA DEL PINO, M. D. (1996) Pechina. En Almería pueblo a pueblo. Madrid: Mediterráneo, 1996, pp. 461-464

SIRET, L. (1893) L'Espagne préhistorique. Revue des Questions Scientifiques, XXXIV, 1893, pp. 537-560

SOLER, J. (1993) Almería, Tierra de Cine. Almeria: Lei Producciones para Canal Sur, 1993 (serie televisiva)

TAPIA GARRIDO, J. A. (1980) Baños de Sierra Alhamilla. Almeria: Cajal, 1980

TORRES, M. R.; NICOLÁS, M. M. (2005) La Alcazaba de Almería y su arquitectura en época cristiana. En La Alcazaba, fragmentos para una historia de Almería. Sevilla: Consejería de Cultura, Junta de Andalucia, 2005, pp.129-146

La VIVIENDA moderna. Registro Docomomo Ibérico: 1925-1965 (2009). Barcelona: Fundación Caja de Arquitectos, 2009

Las publicaciones marcadas con asterisco (*) se encuentran disponibles para su consulta en la Biblioteca del IAPH. 
AGUILERA CANTÓN, Antonio; CUÉLLAR VILLAR, Domingo (coord.). 100 años de ferrocarril en Almería [exposición]. Almería : Instituto de Estudios Almerienses : Asociación de Amigos del Ferrocarril, 1999

ALCOCER Y MARTínEZ, Mariano. Castillos y fortalezas del antiguo reino de Granada. [Ed. facs.]. Valladolid : Maxtor, 2005. Reprod. facs. de la ed. de : Tanger : Publicaciones del Instituto General Franco para la Investigación Hispano-Árabe, 1941 (Serie tercera. Utilización de los archivos españoles ; 6) *

ALMAGRO-GORBEA, Martín. La primera fecha absoluta para la cultura de Los Millares a base del Carbono 14. Ampurias : revista de arqueología prehistoria y etnografía, T. 21, no 21, 1959, p. 249-251 *

ALMERÍA. Granada : Andalucía, D.L. 1983, 4 v. (Nuestra Andalucía) *

ÁVILA GRANADOS, Jesús. Valle del Andarax. Por la ruta de las Alpujarras. Revista del Ministerio de Fomento, 2004, no 535, p. 66-72

BLANCO MARTÍN, Miguel ángel. El cine y su imagen. Almería: Diputación de Almería : III Festival Nacional de Cortometrajes "Almería Tierra de Cine", 1998

CAPEL, Josefa...[et al.]. Aproximación al estudio de procedencia y tecnología de fabricación de las cerámicas campaniformes del yacimiento de la Edad del Cobre de los Millares. En: III Congreso Nacional de Arqueometría : [celebrado del 28 de septiembre al 1 de octubre de 1999 en Sevilla]. Sevilla : Universidad de Sevilla, Secretariado de Publicaciones, 2001, p.207-214 *

\section{CARA BARRIONUEVO, Lorenzo. La Alcazaba} de Almería en época califal : aproximación a su conocimiento arqueológico. Almería : Instituto de Estudios Almerienses, 1990, 71 p. : il. ; 24 cm(Cuadernos monográficos ; 4 *

\section{CARRILERO MILLÁN, Manuel; SUÁREZ}

MÁROUEZ, Ángela. El territorio almeriense en la prehistoria. Almería : Instituto de Estudios Almerienses, Departamento de Historia, 1997 *

\section{COLOOUIO ALMERÍA ENTRE CULTURAS (SIGLOS} XIII-XVI). 1990. Almería. Almería entre culturas (siglos XIII-XVI) : actas del coloquio : Almería, 19, 20 y 21 de abril de 1990. Almeria : Instituto de Estudios Almerienses de la Diputación de Almería, 1990, 2 v. (Actas / Instituto de Estudios Almerienses ; 6) *

CRESSIER, Patrice ...[et al]. Estudios de arqueología medieval en Almería. [Almería] :
Institutos de Estudios Almerienses, D.L. 1992, (Investigación. Historia; 14) *

DURÁN DíAZ, María Dolores. Guía provincial de museos de Almería. Almería : Instituto de Estudios Almerienses, 2006

ESPINOSA SPÍNOLA, María Gloria....[et al.]. Guía artística de Almería y su provincia. Sevilla : Fundación José Manuel Lara. Almeria : Diputación de Almeria, 2006 *

ESOUIVEL GUERRERO, José Antonio; RODRÍGUEZ ARIZA, María Oliva. Una aplicación del análisis de correspondencias en la valoración del antracoanálisis de Los Millares. Cuadernos de la Prehistoria de la Universidad de Granada, n. 14-15, 1989-90, p. 81-108

FERNÁNDEZ MAÑAS, Ignacio; SOLER VIZCAÍNO, Juan; CAPARRÓS MASEGOSA, María Dolores. El cine en Almeria (1970-1975): el final de una época. Cuadernos de arte de la Universidad de Granada, no 26,1995, p. 461-473*

GARCÍA ALFONSO, Eduardo; MARTÍNEZ ENAMORADO, Virgilio; MORGADO RODRíGUEZ, Antonio. Museos arqueológicos de Andalucía. Málaga : Librería Ágora, 1995-1999, 2 v. *

\section{GARCIAA PARDO, Manuela; MARTÍNEZ SAN} PEDRO, Maria Desamparados. Notas sobre los baños de Alhama de Almeria. En: Termalismo antiguo : I Congreso peninsular : actas : Arnedillo (La Rioja), 3-5 octubre 1996. Madrid : Universidad Nacional de Educación a Distancia, 1997, p. 541-544

GONZÁLEZ CALZADA, Juan. Almería, una historia de cine. Tabernas, Almería : Escuela Taller Tabernas de Cine, 2009

GUSI I JENER, Francesc; OLARIA I PUYOLES,

Carme. El poblado neoeneolitico de Terrera-Ventura (Tabernas, Almería). Madrid : Ministerio de Cultura, Dirección General de Bellas Artes y Archivos, Instituto de Conservación y Restauración de Bienes Culturales, 1991

(Excavaciones arqueológicas en España ; 160) *

\section{HARO NAVARRO, Marín; MORENO ONORATO,}

María Auxiliadora. El Centro de Interpretación de Los Millares recrea la vida de la prehistoria andaluza. PH : Boletín del Instituto Andaluz del Patrimonio Histórico, n 58, 2006, p. 14 *

LÁZARO PÉREZ, Rafael. Los Alfeni de "Alba" (Abla, Almería). En: Espacios, usos y formas de la epigrafia hispana en épocas antigua y tardoantigua: homenaje al Dr. Armin U. Stylow. Mérida : Consejo
Superior de Investigaciones Cientificas, Instituto de Arqueologia de Mérida, 2009, p. 187-197. (Anejos de Archivo Español de Arqueología (AEspA); 48) *

MARTíNEZ MOYA, José Enrique. Almería, un mundo de película. [Almería] : Instituto de Estudios Almerienses, 1999

Los MILLARES [DVD-Video] : los fortines de Los Millares : el control de un territorio. [Sevilla] : Junta de Andalucia, Consejería de Cultura, D.L. 2004*

MOLINA GONZÁLEZ, Fernando. Proyecto Millares : Ios inicios de la metalurgia y el desarrollo de las comunidades del sudeste de la Península Ibérica durante la Edad del Cobre. En : Anuario Arqueológico de Andalucía, T.ll: Actividades sistemáticas, 1989, p. 211-213 *

MUSEO Arqueológico, Almería : Paredes \& Pedrosa. AV : Monografias, no 105-106, 2004, p. 86

PÉREZ ESCOLANO, Víctor ...[et al.]. 50 años de arquitectura en Andalucía : 1936-1986 [catálogo de exposición]. Sevilla : Consejeria de Obras Públicas y Transportes, Dirección General de Arquitectura y Vivienda, D.L. 1986 *

RUIZ GARCíA, Alfonso; LANGLE RUBIO, Guillermo. Ciudad Jardín, Almería 1940-1947 : Guillermo Langle Rubio. Almería : Colegio de Arquitectos de Almería, 1998

RUIZ GARCÍA, Alfonso; MUÑOZ MUÑOZ, Juan; JIMÉNEZ TERRÓ, Inmaculada. Recursos culturales y patrimonio. En: Subdesiertos de Almería : naturaleza de cine. Sevilla: Junta de Andalucía, Consejería de Medio Ambiente, 2004, p. 365-395

\section{SUÁREZ, Ángela; ALCALÁ, Francisca. La} musealización del conjunto monumental de la Alcazaba de Almería : una nueva perspectiva para el siglo XXI. En : III Congreso Internacional sobre Musealización de Yacimientos Arqueológicos : de la excavación al público : procesos de decisión y creación de nuevos recursos, Zaragoza, 15, 16 y 17 de noviembre de 2004. [Zaragoza] : Ayuntamiento de Zaragoza : Institución "Fernando el Católico", D.L. 2005 , p. $365-368$ *

Nota: Bibliografia seleccionada por Isabel Guzmán (Biblioteca del IAPH). Para una mayor información puede consultar el catálogo online de la Biblioteca del IAPH (http://www.juntadeandalucia.es) cultura/iaph/absys/abwebp.exe)

Las publicaciones marcadas con asterisco (*) se encuentran disponibles para su consulta en la Biblioteca del IAPH. El resto de las referencias se han localizado en diversas fuentes de información (REBIUN, DIALNET, CSIC, Instituto de Estudios Almerienses...) de ámbito nacional. 